\title{
Detection of problem drinkers in general practice
}

\author{
Citation for published version (APA):
}

Cornel, M. (1994). Detection of problem drinkers in general practice. [Doctoral Thesis, Maastricht University]. Amsterdam Thesis. https://doi.org/10.26481/dis.19940929mc

Document status and date:

Published: 01/01/1994

DOI:

10.26481/dis.19940929mc

Document Version:

Publisher's PDF, also known as Version of record

\section{Please check the document version of this publication:}

- A submitted manuscript is the version of the article upon submission and before peer-review. There can be important differences between the submitted version and the official published version of record.

People interested in the research are advised to contact the author for the final version of the publication, or visit the DOI to the publisher's website.

- The final author version and the galley proof are versions of the publication after peer review.

- The final published version features the final layout of the paper including the volume, issue and page numbers.

Link to publication

\footnotetext{
General rights rights.

- You may freely distribute the URL identifying the publication in the public portal. please follow below link for the End User Agreement:

www.umlib.nl/taverne-license

Take down policy

If you believe that this document breaches copyright please contact us at:

repository@maastrichtuniversity.nl

providing details and we will investigate your claim.
}

Copyright and moral rights for the publications made accessible in the public portal are retained by the authors and/or other copyright owners and it is a condition of accessing publications that users recognise and abide by the legal requirements associated with these

- Users may download and print one copy of any publication from the public portal for the purpose of private study or research.

- You may not further distribute the material or use it for any profit-making activity or commercial gain

If the publication is distributed under the terms of Article $25 \mathrm{fa}$ of the Dutch Copyright Act, indicated by the "Taverne" license above, 
DETECTION OF PROBLEM DRINKERS IN GENERAL PRACTICE 


\section{Paranimfen:}

J.M. Kruyt

dr. T.M. Smits

Aan Wim van Zutphen

Cover design: Guus van Rooy, RL Design

This study was supported by a grant from the 'Netherlands Organisation for Scientific Research' (NWO)

This publication was made possible by E. Merck-Nederland BV 


\title{
DETECTION OF PROBLEM DRINKERS IN GENERAL PRACTICE
}

\section{PROEFSCHRIFT}

\author{
ter verkrijging van de graad van doctor \\ aan de Rijksuniversiteit Limburg te Maastricht, \\ op gezag van de Rector Magnificus, \\ Prof. dr. H. Philipsen, \\ volgens het besluit van het College van Dekanen, \\ in het openbaar te verdedigen op \\ donderdag 29 september 1994 om 16.00 uur
}

door

Michiel Cornel 


\section{Promotores:}

Prof. dr. M.J. Drop

Prof. dr. J.A. Knottnerus

\section{Co-promotor:}

Dr. R.A. Knibbe

\section{Beoordelingscommissie:}

Prof. dr. ir. W.H.M. Saris (voorzitter)

Prof. dr. H.F.L. Garretsen (EUR)

Prof. dr. G.J. Kok

Prof. dr. J.D. Mulder (RUL)

Prof. dr. F. Sturmans 


\section{Contents}

Chapter 1 General introduction 1

Chapter 2 Recognition of problem drinkers and the role of the general practitioner

Chapter 3 Random sampling from a general practice population

Chapter 4 Problem drinking in a general practice population; the construction of an interval scale for severity of problem drinking

Chapter 5 Predictors for hidden problem drinking in general practice

Chapter 6 Reasons for encounter and diagnosis: do they predict hidden problem drinking in general practice?

Chapter 7 General discussion and conclusions

Summary

Samenvatting

Acknowledgements

Appendices -abbreviations

-manual for general practitioners

-form for consultation registration

-questionnaire

-questions of Rasch scale, with Dutch translation -distribution of basic characteristics of the study population 


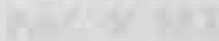

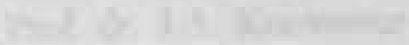

W.

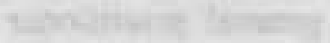

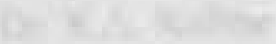

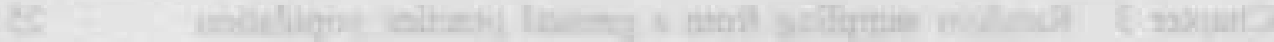

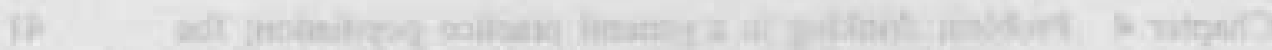
The

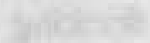

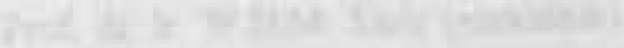

Fith

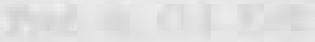

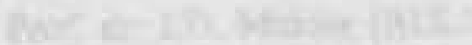

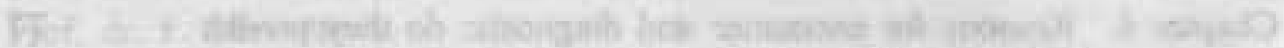

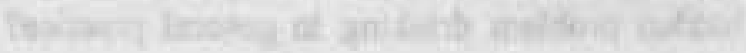

$1\}$

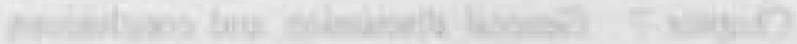

11 i

3. Whathen

Q1

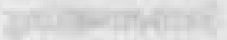

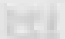

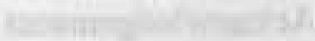

SII

-

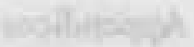

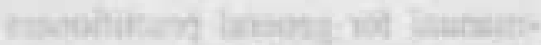

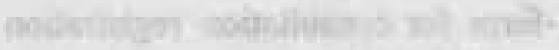

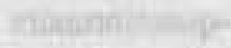

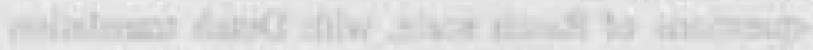

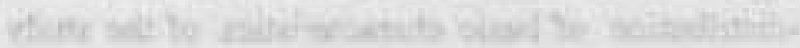

$$
\text { ain } 7 y-\text { ainco }
$$




\section{Chapter 1}

\section{General introduction}

Alcohol is a widely accepted psychoactive agent that is used by a large part of the adult population. In the Netherlands the per capita increase in alcohol consumption between 1960 and 1986 amounted to more than $300 \%$. After this period, the consumption level has more or less stabilized ${ }^{\prime}$. According to results from a general population survey conducted in the Netherlands in 1985, $49 \%$ of the adult population consumes 7 or more glasses per week, while $10 \%$ consumes more than 30 glasses per week ${ }^{2}$. The use of alcohol is far more accepted and hence far more prevalent than the use of other psychoactive agents like cannabis, LSD or heroin. According to Dutch population surveys, about $10 \%$ of the population can be identified as problem drinkers. Problem drinking is said to be a major social and health problem ${ }^{3}$.

In spite of these facts, general practitioners (GPs) estimate prevalence rates of alcohol related problems to be far lower. One of the causes of this discrepancy in prevalence figures is the lack of diagnostic tools the GP has for identifying problem drinkers. The main aim of this study was to provide the GP with tools for identifying those patients. The hypothesis is that characteristics of patients observable during normal practice can help the GPs to identify problem drinkers.

This chapter briefly discusses the effects of alcohol consumption on consumers, because these effects could perhaps be used as characteristics of problem drinkers. Since the definition of alcohol-related problems give rise to confusion, the most important concepts will be discussed. The value of early recognition will be indicated and the reseach questions will be specified.

\section{Effects as characteristics}

The effects of alcohol consumption can be divided into longterm, more or less specific effects and effects that may occur after shortterm exposure. The first group consists of the classical medical problems caused by a longterm high alcohol intake, like cirrhosis of the liver, pancreatitis, fetal alcohol syndrome, cardiomyopathy and malnutrition resulting in the Wernicke Korsakoff syndrome. They are of no value for early recognition. 
There is a wide variety of shorterm effects of alcohol consumption that could in principle, lead to early recognition of alcohol problems. Some shortterm effects are alcohol-specific, like drunkenness, tremor and black-outs. Others, like gastritis, headache and fatigue, may be caused by alcohol consumption. These symptoms occur frequently in the general practice population and may be caused by other factors as well, which makes these problems less useful as predictors for problem drinking. Social problems, such as marital disruption and problems at work are also associated with a high alcohol consumption. For this type of problems, however, the causal relationship is not always clear. Alcohol consumption may result in social problems, but social problems might also be the cause of high alcohol consumption. Since alcohol consumption has a wide variety of effects and associated factors that are not in a one to one relationship, a combination of effects and associated factors can lead to an improved diagnostic prediction.

In etiological or epidemiological research the question of causation is important, as these studies aim at insight into the mechanism and, if possible, intervention. In diagnostic research, characteristics of a subpopulation are important. These characteristics may be effects or associated factors. The fact that social problems and smoking are associated with alcohol abuse allows the selection of a subpopulation with a greater risk of drinking problems. In this context the question of causality is secondary.

\section{Definition of alcohol related disorders}

There is not one concept of 'alcoholism/problem drinking' with one standard operationalization. Studies of the prevalence or characteristics of 'alcoholics/problem drinkers' differ in the criteria used to categorize drinkers. There appear to be mainly three ways to categorize drinkers: firstly, on the basis of drinking behaviour; secondly, on the basis of problems, consequences or behaviour related to drinking; and thirdly, on the basis of a combination of these criteria. The preference for a particular concept and terminology seems to depend on the discipline involved.

Drinkers can be categorized, on the basis of quantity and frequency measures ('self reports'), into mild, moderate and heavy drinkers. There is as yet no consensus about safe limits of alcohol consumption, the most important reason being that the effects of moderate alcohol consumption are difficult to measure. The effects are small, and are also influenced by drinking patterns. For example, a consumption of 3 glasses every day and a consumption of 10 glasses on both Saturday and Sunday result in the same weekly consumption. 
The effects, however, are likely to be different. One of the oldest and bestknown quantity norms is 'Anstie's Alcohol Limit'. He reported in 1870 that the use of $11 / 2$ ounces of pure alcohol $(31 / 2$ glasses) every day, had no negative consequences ${ }^{4}$. The 'Royal College of General Practitioners' today gives a limit of safe alcohol use of 15 standard glasses a week for women and 20 standard glasses a week for men $^{5}$. From a public health point of view, these 'safe limits' have some dangerous aspects. People differ in their degree of vulnerability, and such advice may stimulate light drinkers to drink more. The unintentional mechanism of underreporting alcohol consumption contributes in practice to a higher consumption level ${ }^{2}$, those who think that they drink below the safe limit are likely to drink more.

In the psychiatric (medical) literature terms like alcohol abuse, alcohol dependence and alcoholism prevail. Social sciences prefer to use the term problem drinking, while the medical literature also uses the term problem drinking.

Depending on North American or British influences, clinicians and researchers use the DSM-III related diagnoses ${ }^{6}$ (American Psychiatric Association) or the diagnosis of 'Alcohol Dependence Syndrome', which is used in the ICD97 (World Health Organisation).

DSM-III-R describes alcohol dependence and abuse. Diagnostic criteria for alcohol dependence include at least three of the following, over a period of at least a month or repeatedly for a longer period: (1) alcohol often taken in larger amounts or over a longer period than intended, (2) the desire, or one or more unsuccessful efforts, to cut down or control drinking, (3) spending a great deal of time in activities necessary for obtaining or taking the substance or recovering from its effects, (4) frequent intoxication or withdrawal symptoms when expected to fulfill major role obligations at work, school or home, or when alcohol use is physically hazardous (driving while intoxicated), (5) important social, occupational, or recreational activities given up because of drinking, (6) continued drinking despite the knowledge of having a persistent or recurrent social, psychological, or physical problem that is caused or exacerbated by drinking, (7) marked tolerance, (8) characteristic withdrawal symptoms, (9) substance often taken to relieve or avoid withdrawal symptoms. A diagnosis of alcohol abuse, when there is no dependence, requires the presence of a maladaptive pattern of alcohol use lasting for at least a month or repeated over a longer period of time, which is continued despite the knowledge of having a persistent or recurrent social, occupational, psychological, or physical problem that is caused or exacerbated by the use of alcohol, 
or for the same period of time, recurrent use in situations in which use is physically hazardous (e.g., driving while intoxicated)

The 'Alcohol Dependence Syndrome' was described by Edwards and Gross in 1976 and forms the basis of the criteria of the ICD- $9^{8}$. Essential elements of the syndrome are a narrowing in the repertoire of drinking, salience of drink seeking behaviour, increased tolerance, repeated withdrawal symptoms, repeated relief or avoidance of withdrawal symptoms by further drinking, subjective awareness of compulsive drinking, reinstatement of the syndrome after abstinence. It is essential is that the 'Alcohol Dependence Syndrome' is not an all-or-nothing phenomenon.

There are some important differences between the DSM-III-R criteria and the 'Alcohol Dependence Syndrome' represented in the ICD classification. DSMIII-R does not cover the narrowing of the drinking repertoire and the readdiction liability, but it does include indicators of social and occupational impairment which are not part of the 'Alcohol Dependence Syndrome' of the ICD classification.

\section{Measurement of alcohol related problems}

The above-mentioned concepts can be measured by means of questionnaires. The DSM-III criteria were translated into the Diagnostic Interview Schedule? Questionnaires such as the Michigan Alcoholism Screening Test (MAST) ${ }^{10}$ are more in line with the DSM-III-R criteria, because social and occupational impairment are included. The 'Alcohol Dependence Syndrome' is the basis of the Short Alcohol Dependence Data Questionnaire (SADD) ${ }^{11}$, and the Alcohol Dependence Scale (ADS) ${ }^{12}$.

Problems with a quantity/frequency measure are the validity of self reported consumption and individual differences in vulnerability. For instance, women are more vulnerable than men due to a smaller blood volume, a higher ratio of fat to lean tissue and a more rapid absorption ${ }^{13}$.

As was stated above, the concept of problem drinking is used in a sociological as well as in a medical context. This concept includes the social aspects of the excessive consumption of alcohol. The concept of problem drinking can be defined by a combination of a minimum drinking level and certain magnitude of alcohol related problems. Two Dutch population surveys operationalized problem drinking as a drinking pattern of 6 or more glasses at least once a week or more than 3 glasses at least 21 times a month, in combination with a minimum score on a problem index. This problem index covers several aspects of problem drinking, such as psychological and physical dependence 
on alcohol, loss of control, drinking-related social and health problems, drunkenness and accidents after drinking ${ }^{14}$.

The MAST, which was mentioned above as an alcoholism screening test, also covers these aspects of drinking-related problems. This study will largely use the term problem drinker (PD), since this term covers a variety of drinkingrelated problems and is less stigmatizing than alcoholism. Measurement of problem drinking was performed by means of a questionnaire, the characteristics of which are presented in chapter 4.

\section{Prevalence figures}

Prevalence estimates from the above-mentioned representative Dutch population surveys show that about $10 \%$ of the population can be identified as problem drinkers ${ }^{15}$.

Prevalence estimates in general practice based on questionnaires, vary with the population studied and the screening method used. In a family practice center in Mexico, from a total sample of 147 patients, Leckman reported $19.1 \%$ with a weighted MAST score greater than 5 (extremely likely that the subject is an alcoholic) ${ }^{16}$. In a family practice center in Chicago, Hotch found $18 \%$ of the patients seen over an eight-week period to have a MAST score of 6 or higher, i.e. the same prevalence ${ }^{17}$. In both studies men scored higher than women. In a primary care setting in Sao Paulo, $5 \%$ of the population were found to have a score of 2 or more on the CAGE questionnaire, which means they were considered to be at risk ${ }^{18}$. Using the same questionnaire, a $9.3 \%$ prevalence rate was found in a general practice setting in London ${ }^{19}$. Limbeek, using the Münchener Alcoholismus Test (MALT), found 10.5\% male PDs and 5.6\% female PDs ${ }^{20}$.

Dutch prevalence figures from general practice indicate that between $1 \%$ and $2 \%$ of the general practice population is diagnosed by GPs as having an alcohol problem ${ }^{21,22}$. This finding concerns patients with a diagnosis of chronic alcohol abuse according to the ICD-9 criteria.

There is a large difference between the above-mentioned prevalence estimates based on screening and the $1 \%-2 \%$ prevalence estimate of alcohol abuse based on registration by GPs.

This difference can be partly explained by the more restrictive definitions used by GPs (medical model of alcoholism) or by their fear or restraint in assigning the label of problem drinker to their patients. However, there remains a gap that can be ascribed to non-recognition by the GP. Improvement of the GP's 
recognition of problem drinkers, preferably at an early stage, is likely to contribute to a better health care.

\section{Why early recognition?}

There is some discussion about the role of the GP in the early diagnosis of problem drinking by screening or case finding. Screening involves the general population, e.g. the general practice population, while case finding aims at the detection of individual cases in a patient population when patients come to their doctors for unrelated illnesses. The subject of the present study is case finding in problem drinking.

The high prevalence of problem drinking, the negative consequences for health and social functioning, and the expectation of prevention on the one hand, and the fact that $75 \%$ of the population sees a GP at least once a year, while $95 \%$ see one at least once every 5 years on the other, make case finding a promising enterprise.

Sackett has formulated a set of questions to be asked before coming to an early diagnosis ${ }^{23}$. Points most relevant in the present context include:

(1) does early diagnosis really lead to improved clinical outcome?; (2) will patients in whom an early diagnosis is achieved comply with your subsequent recommendations and treatment regimens?; (3) does the burden of disability from the target disease warrant action?; (4) are costs, accuracy, and acceptability of the screening test adequate for your purpose?

The early diagnosis of problem drinking satisfies some of these criteria. As for the first criterion: early diagnosis in combination with brief intervention has been found to be promising ${ }^{24}$, although research in this field is sparse. With regard to the second criterion: this point is more problematic, since problem drinking is not easy to treat. Problem drinkers tend to deny their problems and their drinking, and to emphasize the positive effects of alcohol consumption. They are often not motivated to change their drinking habits. It is possible that compliance for brief intervention or treatment is better at an early stage. As regards to the third criterion: the burden of 'disability' warrants action since the effects of heavy drinking at a later stage are serious. Finally, with regard to the fourth criterion: cost and accuracy have not been studied, while the acceptability of the GP's concem about drinking behaviour is good ${ }^{25}$.

\section{How early detection be achieved?}

Detection by the GP could be done with existing questionnaires or laboratory screening. However, the systematic use of questionnaires on large parts of the 
patient population does not fit in with the working style of the GP, while blood tests are not sufficiently sensitive and specific ${ }^{26,27}$.

The Dutch College of General Practitioners, acknowledging the importance of the recognition of problem drinkers in general practice, has developed a 'Standard' for the detection of problem drinkers ${ }^{28}$. It is thought that such a guideline can improve case finding in general practice ${ }^{29}$.

This Standard contains background data and consultation data that should raise the GP's suspicion of problem drinking. The 'predictors' of problem drinking are based on the literature. These sources suggest that background variables, consultation rates and medical problems are different for problem drinkers than for non-problem drinkers. However, studies of problem drinkers in general practice populations have so far been largely restricted to a certain selection of problem drinkers, namely those known to the $\mathrm{GP}^{30}$. This is an important limitation of these studies, and it is questionable whether data from known problem drinkers also apply to problem drinkers not known as such to the GP. Until now, no large scale exploratory investigations have been carried out that focus on problem drinkers not recognized as such by their physician, and more specifically on the question whether problem drinkers not known to the GP differ from other patients with respect to medical profile (consultation rates, presenting problems and diagnoses) and/or background factors. Differences between problem drinkers who are not known as such to their GPs and patients who have no drinking problems could be especially helpful in the detection of hidden problem drinkers. From this goal follow the main research questions.

\section{Research questions}

In contrast to other studies about problem drinking in general practice, this study distinguishes between problem drinkers already known as such to their GPs and problem drinkers not known as such to their GPs (hidden problem drinkers).

In this design known problem drinkers and hidden problem drinkers had to be distinguished from the rest of the population. Known problem drinkers were selected by the GPs, while hidden problem drinkers were identified by a screening questionnaire. Since no proper validation of questionnaires has been performed in general practice in the Netherlands, the construction of a questionnaire was one part of the study.

One of the hypotheses of the present study is that variables already known to or easily available for the GP can help to select patients with a greater risk of 
problem drinking, in order to make a more specific diagnostic inquiry more efficient. Therefore, the study aimed to establish whether problem drinkers differ in variables that are known to or routinely used by GPs. Examples of these include consultation rates, complaints (reasons for encounter), diagnoses (evaluation) and background variables.

The following research questions were formulated:

1. Is it possible to construct a screening instrument on problem drinking in a general practice population, based on existing screening questionnaires?

2. What is the prevalence of problern drinkers among patients who visit their GPs over a one year period?

3. How many of these problem drinkers are recognized by the GPs?

4. Can unrecognized problem drinkers be distinguished on the basis of background variables?

5. Can unrecognized problem drinkers be distinguished on the basis of reasons for encounter and diagnoses?

\section{Study design}

To answer these questions a follow up study was conducted. Patients who had visited their GP at least once over a one year period were eligible for inclusion in the study. At their first visit, all problem drinkers known as such by the GPs, plus a random sample of the rest of the practice population, received a questionnaire. The questionnaire comprised a screening instrument for the detection of problem drinking as well as questions about background variables. The most important variables were: gender, age, marital status, education, work, life events, social problems, chronic illness, use of tranquillizers or sleeping pills and smoking. Patients who were included were followed for the rest of that year by the GP. The GP registered all consultations on a specially designed registration form. Main variables were Reason For Encounter (RFE) and Evaluation/diagnosis $(\mathrm{E})$, which were written down in free text and coded 
centrally according to the International Classification of Primary Care ${ }^{31}$. In this publication the terms 'evaluation' and 'diagnosis' are interchangeable and also can both refer to a symptom diagnosis.

Three groups of patients were distinguished. The first was that of problem drinkers identified as such by their GP, i.e. known problem drinkers. The second consisted of hidden problem drinkers and the third of normal drinkers or abstainers.

The most important part of the population was the category of patients who were not problem drinkers according to the GPs. This category was divided by screening into two categories: hidden problem drinkers and non-problem drinkers. If unidentified problem drinkers should be found to differ from the other categories on one or more of the variables, detection could be facilitated because this would allow the GP to select patients at greater risk of problem drinking.

Known problem drinkers were included in the study for several reasons. Firstly, to calculate prevalence figures for the whole practice population; secondly, to study contrasts with the hidden problem drinkers. The contrast between hidden and known problem drinkers could perhaps provide information about the reasons why some problem drinkers are recognized and others are not.

\section{Screening instrument}

A prerequisite for this study was a reliable instrument for the detection of unidentified problem drinkers. The literature describes different screening methods, varying from biochemical parameters to extensive interviews. The present study used a self-administered questionnaire, because this is more reliable than biochemical parameters and less time-consuming than personal interviews ${ }^{32}$.

The choice of a screening instrument, which had to be made at the beginning of the project, was difficult. There was no questionnaire that had been properly validated in general practice. Most of the existing instruments have been validated for in-patient populations. An important factor in the choice of an instrument was that the questionnaire had to be self-administered. The questions had to be friendly, not too confronting. This criterion excluded questionnaires that focus on addiction.

The three most commonly used instruments, CAGE ${ }^{33}, \mathrm{SMAST}^{34}$ and a shortened version of SAAST ${ }^{35}$ were chosen for inclusion in the questionnaire. 
This choice allowed comparisons to be made with other studies. The intention was to construct a new scale, based on a combination of these three screening questionnaires, combined with some additional questions relevant to the general practice setting. With the help of a Rasch analysis, an advanced scaling technique, a homogeneous scale was to be constructed. The Rasch technique is interesting, since the resulting interval scale indicates seriousness of problem drinking. If the construction of the new scale turned out to be unsuccessful, the SAAST was to be chosen as the criterion.

\section{Structure of this thesis}

Since chapters 2 to 6 are based on papers intended for publication in journals, the methodology sections partly overlap. These chapters can be read seperately.

Chapter 2 of this thesis presents the results of a literature study on the recognition of problem drinkers in general practice. Mechanisms leading to underreporting of problem drinkers are discussed.

Chapter 3 presents the methodology of sampling from the group of patients who were not problem drinkers according to the GPs. All patients who were a problem drinkers according to the GPs were included in the study. The 1 in 10 sampling among the group of patients who were not problem drinkers according to the GPs was necessary since the workload for the GPs would not be acceptable otherwise. It also made for a more efficient use of the patients involved in the study.

Chapter 4 describes the development of the screening questionnaire on the basis of a Rasch analysis.

Chapter 5 presents the results of the prediction of problem drinking using background variables like gender, age, social problems and smoking.

Chapter 6 deals with the diagnostic value of RFEs and Es in the recognition of problem drinking. A selection of RFEs and Es was made on the basis of the 'Dutch Alcohol Standard' on problem drinking developed by the Dutch College of General Practitioners.

Chapter 7 presents an overview of the results, with discussion and conclusions. 
1. Commodity Board for Distilled Spirits. World Drink Trends. NTC Publications Ltd, United Kingdom, 1991.

2. Lemmens PHHM, Tan ES, Knibbe RA. Measuring quantity and frequency of drinking in a general population survey: a comparison of five indices. J Stud Alcohol 1992;53:476-86.

3. Ministerie van Welzijn, Volksgezondheid en Cultuur. Alcohol en samenleving: ontwerp-Nota over een samenhangend alcoholmatigingsbeleid. Tweede Kamer, 1986-87, 19243, 2-3, Staatsuitgeverij, 's-Gravenhage, 1987.

4. Anstie FE. On the uses of wine in health and disease. New york, Redfield, 1870.

5. Anonym. Alcohol a balanced view. Report from General Practice 24. London, Exeter Publications Office, 1985.

6. American Psychiatric Association: Diagnostic and Statistical Manual of Mental Disorders, third edition, revised. Washington, DC, American Psychiatric Association, 1987.

7. World Health Organization. Manual of the International Statistical Classification of Disease, Injuries and Causes of Death. 1975 (9th) revision, WHO, Geneva, 1978.

8. Edwards G, Gross MM. Alcohol dependence: provisional description of a clinical syndrome. Brit Med J 1976;1:1058-61.

9. Robins LN, Helzer JE, Croughan J, Ratcliff KS. National Institute of Mental Health Diagnostic Interview Schedule; its history, characteristics, and validity. Arch Gen Psychiat 1981;38:381-9.

10. Selzer ML. The Michigan Alcoholism Screening Test: The quest for a new diagnostic instrument. Am J Psychiat 1971;127:1653-8.

11. Davidson R, Bunting B, Raistrick D. The homogeneity of the Alcohol Dependence Syndrome: a factorial analysis of the SADD questionnaire. $\mathrm{Br} \mathrm{J}$ Addict 1989;84:907-15.

12. Skinner HA, Allen BA. Alcohohol Dependence Syndrome: measurement and validation. J Abnormal Psychology 1982;91:199-209.

13. Dunne F. Are woman more easily demaged by alcohol than man? Br J Addict 1988;83:1135-6. 
14. Knibbe RA. Van gangbaar tot problematies drankgebruik. (From everyday drinking to problematic drinking). [dissertation]. Maastricht: University of Limburg, 1984.

15. Garretsen HFL, Knibbe RA. Two Dutch surveys on problemdrinking. Med Sci Law 1985;4:265-8.

16. Leckman AL, Umland BE, Blay M. Prevalence of alcoholism in a family practice center. J Fam Practice 1984;18:867-70.

17. Hotch DF, Sherin KM, Harding PN, Zitter RE. Use of the Self-Administered Michigan Alcoholisrn Screening Test in a family practice center. J Fam Practice 1983;17:1021-6.

18. Iacoponi $E$, Laranjeira $R R$, Jorge $M R$. At risk drinking in primary care: report from a survey in Sao Paulo, Brazil. Br J Addict 1989;84:653-8.

19. King $\mathrm{M}$. At risk drinking among general practice attenders: prevalence, characteristics and alcohol-related problems. Br J Psychiat 1986;148:533-40.

20. Limbeek van J, Walburg A. De vroege opsporing van alcoholproblematiek [dissertation]. Lisse, Zwets \& Zeitlinger, 1987.

21. Lamberts $\mathrm{H}$, Brouwer $\mathrm{H}$, Groen ASM, Huisman $\mathrm{H}$. Het transitiemodel in de huisartspraktijk. Supplement May 1st 1987 on ICPC rubrics P15, P16. Huisarts \& Wet. 1987;30:105-13.

22. Registration Network Family Practices. Health problems and diagnoses in family practice, University of Limburg, The Netherlands, Maastricht, 1992.

23. Sackett DL, Haynes RB, Tugwell P. Clinical epidemiology, a basic science for clinical medicine. First edition, Boston, 1985.

24. Wallace P, Cutler S, Haines A. Randomised controlled trial of general practitioner intervention in patients with excessive alcohol consumption. Brit Med J 1988;297:663-8.

25. Wallace $P G$, Brennan PJ, Haines AP. Are general practitioners doing enough to promote healthy lifestyle? Findings of the Medical Research Counsil's general practice research framework study on lifestyle and health. Brit Med J 1987;294: 940-942.

26. Skinner HA, Holt S, Sheu WJ and Israel Y. Clinical versus laboratory detection of alcohol abuse: the alcohol index. Brit Med J 1986;292:1703-8.

27. Beresford TP, Blow FC, Hill E, Singer K, Lucey MR. Comparison of CAGE questionnaire and computer-assisted laboratory profiles in screening for covert alcoholism. Lancet 1990;336:482-5. 
28. Van Zutphen WM, Van Olst EJ, Cornel M, Willink AE, Hoeksema HL. NHGstandaard 'Problematisch alcoholgebruik'. Huisarts \& Wet. 1990;33:280-5.

29. Grol R. National standard setting for quality of care in general practice: attitudes of general practitioners and response to a set of standards. J Roy Coll Gen Pract 1990;40:361-4.

30. Rush B, Brennan $M$. Is the health profile of problem drinkers different from that of other patients? J Fam Pract 1990;31:42-6.

31. Lamberts H, Wood M. International Classification of Primary Care. New York, Oxford University Press, 1987.

32. Rolnick SJ, Gross CR, Garrard J, Gibson RW. A comparison of response rate, data quality, and costs in the collection of data on sexual history and personal behaviors. Mail survey approaches and in-person interview. Am J Epidemiol 1989;129:1052-61.

33. Mayfield D, McLeod G, Hall P. The CAGE questionnaire: Validation of a new alcoholism screening instrument. Am J Psychiat 1974;131:1121-3.

34. Selzer ML, Vinokur A, Van Rooijen L. A self-administered Short Michigan Alcoholism Screening Test (SMAST). J Stud Alcohol 1975;36:117-26.

35. Davis LJ, Hurt RD, Morse RM, O'Brien PC. Discriminant analysis of the SelfAdministered Alcoholism Screening Test. Alcohol Clin Exp Res 1987;11:269-73. 


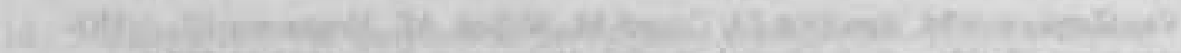

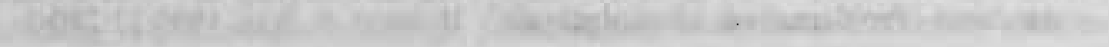

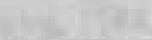

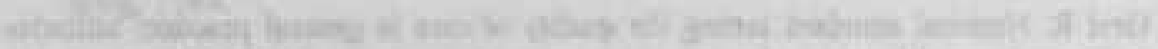

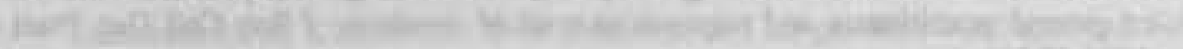

10. Whohnot:

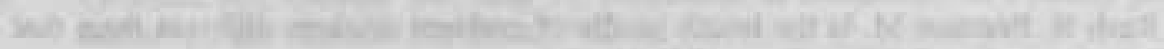

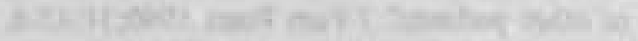

14.

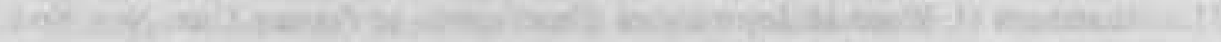

I wata

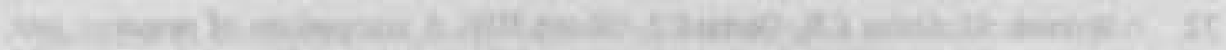

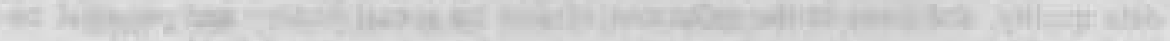

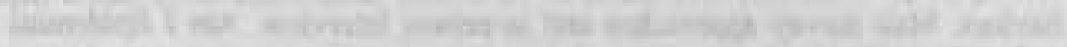

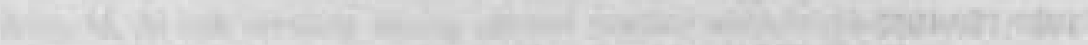

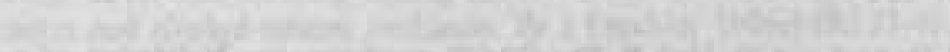

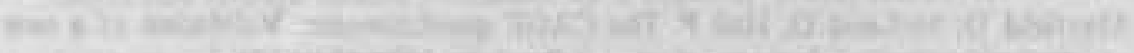

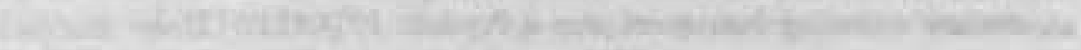

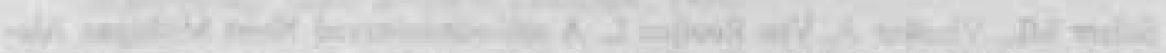

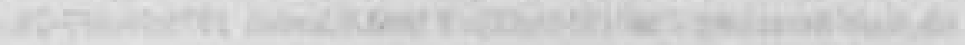

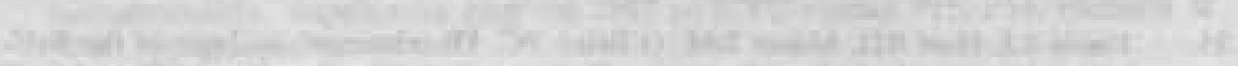

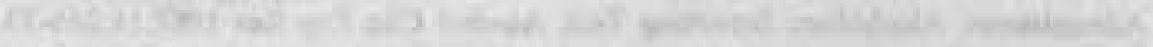

7.

-

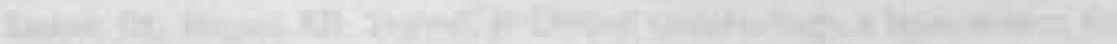

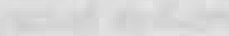

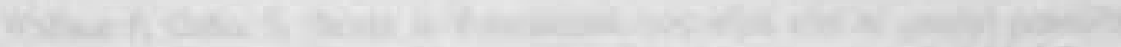

.

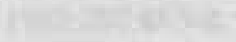

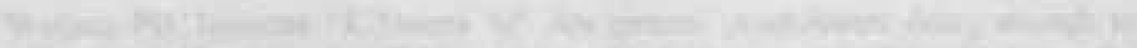

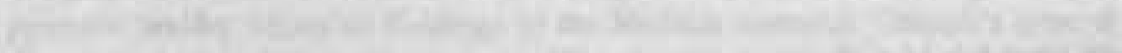

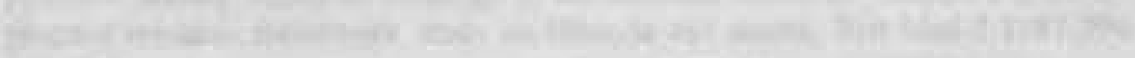

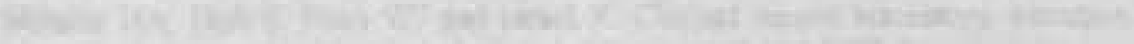

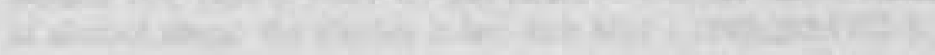

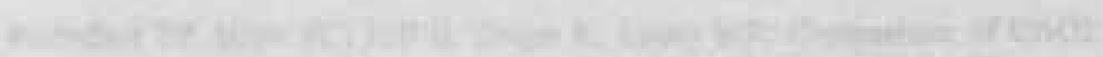

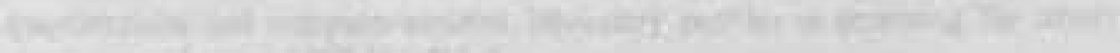

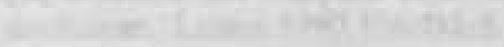


Chapter 2

Recognition of Problem Drinkers and the Role of the General Practitioner

Published in the Canadian Family Physician 1989;35:167-9.

M. Comel, MD

W.M. van Zutphen, MD, PhD

Department of General Practice

University of Limburg

P.O. Box 616

$6200 \mathrm{MD}$ Maastricht

The Netherlands 


\section{Summary}

General practitioners are often visited by patients who have problems related to their drinking behaviour, but only a small proportion of these problem drinkers are recognized as such. Some mechanisms of this non-recognition phenomenon are discussed. Suggestions are made which may enhance early recognition. 


\section{Introduction}

Alcoholism and problem drinking are considered to be among the major risk factors of health and social problems in the United States, the United Kingdorn and Canada'.

In the Netherlands the per capita increase in alcohol consumption between 1960 and 1986 amounted to more than 300 per cent ${ }^{2}$. This increase in mean alcohol consumption occurred in all categories of drinkers. Proportionally, the increase in the number of drinkers was highest in the higher consumption categories ${ }^{3}$.

Dutch prevalence figures from representative surveys of the populations in the city of Rotterdam and the province of Limburg showed that $7.1 \%$ of the Rotterdam population and $10.8 \%$ of the Limburg population could be identified as problem drinkers ${ }^{4}$. These surveys also revealed that problem drinkers under the age of 30 had more health problems and visited their general practitioners more often than those who were not problem drinkers.

\section{Problem drinkers in general practice}

A higher consultation rate of problem drinkers was not only found in the abovementioned community study, but also in a retrospective study from general practitioners' records ${ }^{5}$. In the latter study, $3.3 \%$ of the male and $0.5 \%$ of the female practice population were identified as having a drinking problem. This group was found to have a doctor contact rate of almost twice that of a control group.

Although the general practitioner is consulted more frequently by patients with alcohol-related problems, only a minority of these are recognized as such by him $^{6}$.

In his retrospective analysis of the records of general practitioners, Buchan reported a higher occurrence of social, interrelational, smoking and accidentrelated problems, as well as psychological and gastrointestinal disorders among, patients with drinking problems compared to normal controls $\mathbf{s}^{5}$. Hore and Wilkins found that almost the same symptoms were reported to the general practitioners in a group of patients who were referred to a Regional Alcoholism Treatment Unit. However, no comparison was made with a control group?. In their study it was also found that only $13.9 \%$ of the referred patients had been diagnosed as alcoholics by the general practitioner. 
Kamerow reported in a review that general practitioners only recognized $10 \%$ of problem drinkers ${ }^{8}$. An Australian study, using the Australian Medical Association criteria, demonstrated that general practitioners identified $27.5 \%$ of the high risk drinkers and $45.2 \%$ of the moderate to heavy drinkers ${ }^{9}$. In a study in a family practice center Leckman reported that, out of 24 cases of alcoholism identified by the MAST, this diagnosis was actually made by the general practitioner in only 12 cases ${ }^{10}$. Coulehan found that primary care physicians identified $40 \%$ of patients suffering from alcohol or other substance abuse, as diagnosed by a structured psychiatric interview6.

The figures from various studies about problem drinkers are not comparable, because different criteria were used for the various categories of drinkers. Nevertheless, it is quite obvious that doctors often do not consider the possibility that certain complaints and health disorders might be caused by prolonged excessive consumption of alcoholic beverages.

\section{Recognition of problem drinkers in general practice}

Many explanations for the inadequate recognition of problem drinking have been offered in the literature $6,8,9,11,12,13$. Three main groups of factors can be distinguished: doctor-related factors, patient-related factors and diagnostic factors. These will be briefly discussed below.

\section{Doctor-related factors}

In his study of primary health care patients Coulehan attributed doctors' failure to recognize problem drinkers among their patients to their idea of the characteristics of the typical alcoholic ${ }^{6}$. General practitioners tended to recognize problem drinking more often in elderly than in younger alcoholics among their patients. It appeared that doctors were better able to recognize alcohol related problems in patients with antisocial personality disorders and in patients who were multiple drugs users. These stereotyped ideas may have been influenced by the older stereotype of the 'skid row' alcoholic ${ }^{11}$. In fact, however, as the Dutch community study by Knibbe has shown, problem drinking is now found most frequently among young adults ${ }^{4}$.

General practitioners thus tend to identify only the most obvious and most serious cases. The alcoholics thus identified are seen by the doctors as difficult to treat and as having a poor prognosis. Attempts to deal with their problems may appear to them as quite futile. Those alcoholics who would be easier to 
treat, those with a better prognosis, are generally not often identified, hence do not receive care for their drinking problems.

Many physicians also experience difficulties in discussing a delicate subject such as alcohol consumption. They are afraid that inquiring about the amounts of alcoholic beverages will hurt the patient's feelings ${ }^{12}$. Moreover, physicians are usually not trained to discuss drinking problems with their patients ${ }^{8,11}$. For all the above-mentioned reasons, general practitioners are not strongly motivated to search for problem drinking, let alone to attempt to treat problem drinking among their patients.

\section{Patient-related factors}

Patients rarely mention spontaneously how much they drink, and when they are asked about it, they tend to minimize the amounts of alcohol they consume ${ }^{3}$. There may be several reasons for this. Some patients are not aware of the relation between their physical symptoms and their use of alcohol ${ }^{13}$. Others are more inclined to complain about somatic disorders, because of the common belief that a doctor can be consulted for somatic problems only ${ }^{14}$. The fear of being labelled an alcoholic, which has a highly negative connotation, might also play a role. In this context it is important what the patient thinks about his doctor's perception of alcoholism.

Murphy concluded that both patient and doctor are willing to approach each other $^{13}$. The patient is concerned about his excessive drinking. He mentions being concerned about it, but does not ask for help directly because he does not want to play a patient role with respect to his drinking problems. Since the patient role is a feature of the patient-doctor interaction, this attitude puts the patient in a role conflict with the doctor. The patient retains a better self image when he rejects help and the physician may feel threatened by the hidden challenge to his authority.

Although most patients do not openly discuss problems related to their drinking behaviour, a considerable proportion of them expect their general practitioner to give advice ${ }^{15}$. Findings from Wallace's study on lifestyle assessment and the role of the general practitioner indicate that, in fact, advice about drinking is given very infrequently by general practitioners 15 .

\section{Diagnostic factors}

All the general practitioner has at his disposal are diagnostic criteria derived from clinical studies in selected patient populations in hospitals, psychiatric clinics and alcoholism treatment units. As a result of the selection bias, the 
data from the populations studied have a poor validity for the majority of problem drinkers in general practice. Proper epidemiologic data with regard to the occurrence and course of problem drinking in general practice are indispensable if one wants to arrive at a scientific specification of patient management by general practitioners. For the time being, the general practitioner has to base his diagnosis on an estimation of prior probabilities.

\section{How useful is the identification of problem drinkers?}

Up till now, there have not been any controlled trials demonstrating that early detection more often leads to a better treatment outcome ${ }^{16,17}$. It is, however, generally assumed that early identification of problem drinkers improves the chances of successful intervention'. Skinner and Wallace even maintain that after early detection minimal intervention alone will be successful ${ }^{1,15}$. They refer to the effectiveness of minimal intervention in smoking ${ }^{18,19}$. Wallace demonstrated that patients are concerned about their lifestyle and expect their general practitioner to take an interest in this matter. Patients welcome relevant counselling and health promotion.

\section{Discussion}

The literature reviewed above reveals that the following factors play an important role in the poor recognition of problem drinkers in general practice.

- Doctors tend to stereotype problem drinkers and most of them are not trained in talking to their patients about problem drinking. They seldom give advice on the misuse of alcoholic beverages and its consequences.

- Patients generally fear to be labelled alcoholics, which has a negative connotation. They reject a patient role with regard to problem drinking.

- There are no adequate diagnostic means for the early detection of problem drinking, as a result of the lack of relevant epidemiologic data and patient characteristics from general practice.

Although the usefulness of early recognition of problem drinking has not yet 
been proved by controlled trials, it is most likely that early detection may lead to a better treatment outcome, perhaps even with minimal intervention.

Besides this treatment aspect we can distinguish another effect of the early recognition of problem drinkers. If the doctor concludes that drinking is the underlying factor of certain symptoms and complaints, superfluous and expensive diagnostic procedures can be prevented. The earlier the assessment is made, the better the chances of preventing somatic fixation ${ }^{20}$.

To achieve early recognition of problem drinking, doctors should change their stereotyped ideas about problem drinkers. They should also be trained in discussing drinking problems. This could be achieved by improving medical education, postgraduate training programmes and peer group evaluation ${ }^{21}$.

There is a need for epidemiologic data in general practice to provide insight into specific indicators and prognostic factors for the occurrence and course of problem drinking.

Several studies of symptoms and complaints of problem drinkers have been undertaken in general practice ${ }^{5,6,7}$. These studies have described relevant features of problem drinkers, but their designs were not suitable for determining the predictive diagnostic value of these features. There is still a need for epidemiologic research providing indicators of problem drinking in general practice. To find these indicators, the authors of this paper have planned an observational study in general practices, in which problem drinkers detected by screening will be compared to those who are not problem drinkers. Problem drinkers recognized as such by general practitioners will be compared to problem drinkers who were not recognized. These groups will be compared as regards symptoms, complaints and diagnosis. Our hypothesis is that patients with vague complaints are overrepresented in the group of unrecognized problem drinkers.

Acknowledgements; The authors are indebted to Prof. Dr. M.J. Drop, Dr. R.A. Knibbe and Prof. Dr. G. Saenger for their critical reading of the manuscript. 


\section{References}

1. Skinner HA, Allen BA, McIntosh MC, Palmer WH. Lifestyle assessment: just asking makes a difference. Brit Med J 1985;290:214-6.

2. Commodity Board for Distilled Spirits. World Drink Trends. NTC Publications Ltd, United Kingdom, 1991.

3. Knibbe RA, Drop MJ, Van Reek J, Saenger G. The development of alcohol consumption in the Netherlands: 1958-1981. Brit J Addict 1985;80:411-9.

4. Knibbe RA Van gangbaar tot problematies drankgebruik. (From everyday drinking to problematic drinking). Dissertation, Maastricht 1984, University of Limburg.

5. Buchan JC, Bucki EG, Deacon GLS, Irvine R, Ryan MP. Problem drinkers and their problems. J Roy Coll Gen Pract 1981;31:151-3.

6. Coulehan $\mathrm{J}$, Zettler-Segal M, Block M, et al. Recognititon of alcoholism and substance abuse in primary care patients. Arch Int Med 1987;147:349-52.

7. Hore BD, Wilkins RH. A general practice study of the commonest presenting symptoms of alcoholism. J Roy Coll Gen Pract 1976;26:140-2.

8. Kamerow DB, Pincus HA, Macdonald DJ. Alcohol abuse, other drug abuse, and mental disorders in medical practice. JAMA 1986;255:2054-7.

9. Reid ALA, Webb GR, Hennrikes D, Fahey PP, Sanson-Fisher RW. Detection of patients with high alcohol intake by general practitioners. Brit Med J 1986; 293:735-7.

10. Leckman $\mathrm{AL}$, Umland $\mathrm{BE}$, Blay $\mathrm{M}$. Prevalence of alcoholism in a family practice center. J Fam Pract 1984;18:867-70.

11. Schuckit MA. Why don't we diagnose alcoholism in our patients? J Fam Pract 1987;25:225-6.

12. Wallace PG. The detection and assessment of patients at risk because of their drinking. Practitioner (Eng) 1987;231:287-93.

13. Murphy HBM. Hidden barriers to the diagnosis and treatment of alcoholism and other alcohol misuse. J Stud Alcohol 1980;41:417-28.

14. Van Zutphen W, Saenger G, Hendrix J. Psychological and social complaints reported by Dutch patients to their family doctors. Scand J Primary Health Care 1988;6:73-6. 
15. Wallace PG, Brennan PJ, Haines AP. Are general practitioners doing enough to promote healthy lifestyle? Findings of the Medical Research Counsil's general practice research framework study on lifestyle and health. Brit Med J 1987;294: 940-2.

16. Ogbome AC. Patient characteristics as predictors of treatment outcomes for alcohol and drug abusers. In: Israel Y, Glaser FB, Kalant H, et al. (Eds) Research advances in alcohol and drug problems, Vol 4, pp. 177-223, New York and London, 1974 Plenum Press.

17. Cambell TL. An opposing view. J Fam Pract 1987;25:184-7.

18. Russell MAH, Wilson C, Taylor C, Baker CD. Effect of general practitioners' advice against smoking. Brit Med J 1979;2:231-5.

19. Jamrozik K, Vessey M, Fowler G, et al. Controlled trial of three different antismoking interventions in general practice. Brit Med J 1984;288:1499-502.

20. Van Eijk JTM, Grol R, Huygen FJA et al. The family doctor and the prevention of somatic fixation. Family Systems Medicine 1983;1:5-15.

21. Rijdt-van de Ven AHJ, Touw AM, Vermuë MJ, Kluver RIM, De Groot JB. Peer group performance, review for general practitioners, Utrecht, 1988, Stichting $\mathrm{O} \& \mathrm{O}$. 


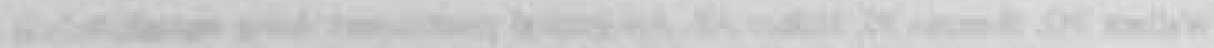

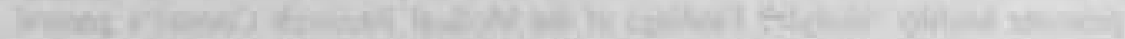

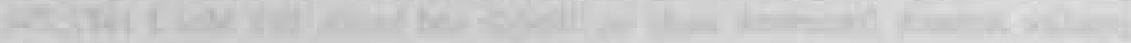
$\sqrt{2014}$

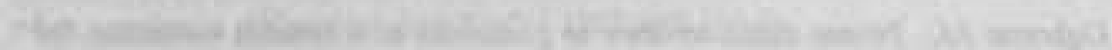

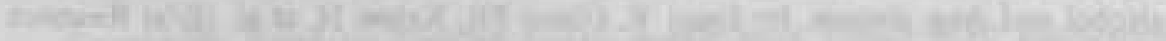

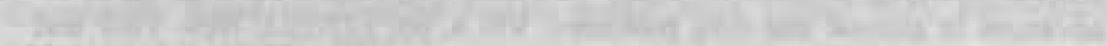

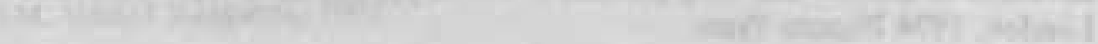

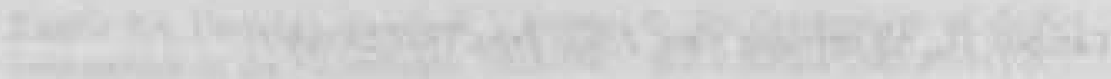

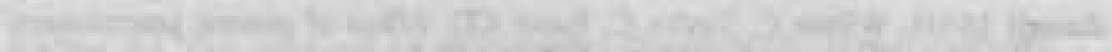

- 20

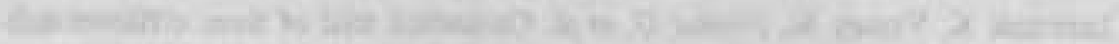

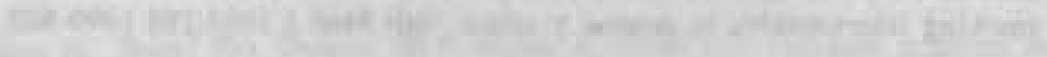

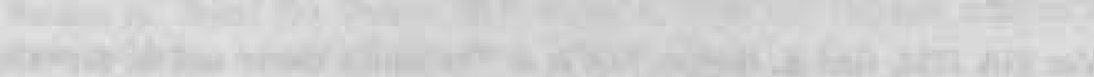

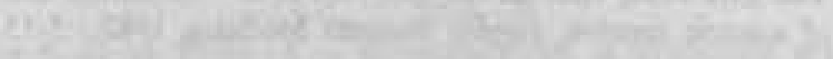

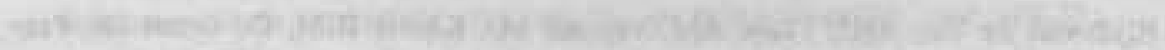

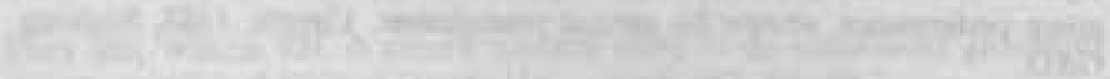

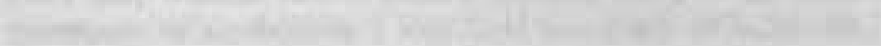

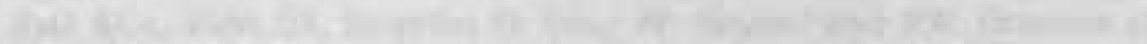
and

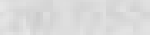

17: 15:

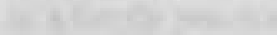

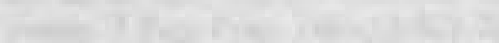

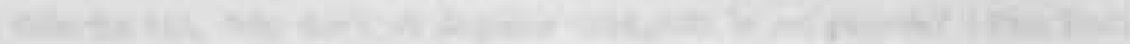
14.

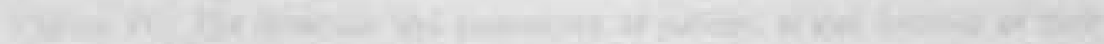

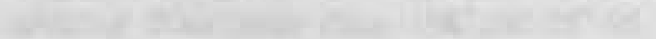

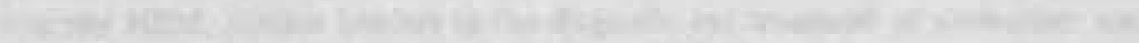
ant

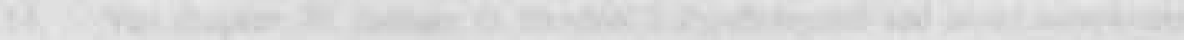

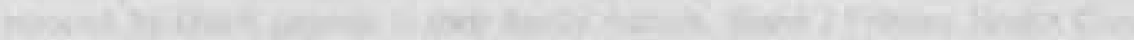

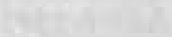




\section{Chapter 3}

\section{Random sampling from a general practice population}

Submitted for publication.

M. Cornel, MD, General Practitioner *

W.M. van Zutphen, MD, PhD, General Practitioner *

R.A. Knibbe, PhD, Medical Sociologist **

M.J. Drop, PhD, Medical Sociologist **

* Department of General Practice, University of Limburg

** Department of Medical Sociology, University of Limburg

Correspondence:

M. Comel

Department of General Practice

University of Limburg

P.O. Box 616

6200 MD Maastricht

The Netherlands 


\section{Summary}

Within the context of a general practice study, a random sample was taken from a part of the study population. This sampling was necessary in order to achieve an acceptable level of effort for the physicians taking part in the research project. In addition, it led to a more efficient study design. The sampling was done by the general practitioners themselves, during surgery hours, using a purpose-built 'random selector'. The findings of the study allow the conclusion that this is a reliable technique for taking samples. Both physicians and patients showed good compliance. 


\section{Introduction}

In studies comparing a part of the population, who share a particular characteristic or disease, with the rest of the population, the research groups are usually of unequal sizes. This is particularly true if the subpopulation to be investigated is characterized by a rare feature or suffers from a rare disease. Retrospective case-control studies which compare cases with controls select their control patients by means of sampling from a comparable population. Such sampling is always done afterwards. In a prospective study, where the cases are already known at the beginning of the observation period, the selection by means of sampling can precede the observation period of the study.

The study of 'Detection of problem drinkers in general practice' illustrates this situation. The smallest category consisted of patients known by their GP to have an alcohol problem. These were compared with problem drinkers not known as such to their GPs and with a category of general practice patients who had no drinking problem. The latter two categories were, respectively, 10 and 100 times the size of the category of recognized problem drinkers.

The unequal sizes of the study groups made it necessary to take a sample from the second and third categories. There are various ways to determine which patients are to be included in the sample and which ones are not. Depending on the research question and the study design, the study population will involve either the entire patient register or only those who visit the doctor's surgery during a specified period.

Sampling from the entire population might be done by marking patients' file cards prior to the start of the study. If the study is to include several practices, this will mean a great deal of work, the more so since not all practices file their patients in the same way. Most practices use family files, which would have to be searched. Since this amount of work could only be done by the researcher or his assistant, this would create problems of privacy.

In the study referred to above, a sample was taken from the category of people who visited the surgery during a specified period. The sampling was done by the general practitioners involved in the research project, during surgery hours. To produce a reliable sample, the sampling method must meet a number of requirements. It must be easy to perform, so that it does not take up too much time during the surgery, and the method must not lead to selection bias. Although general practice research frequently involves taking samples from the patient population, which may present various problems, the general 
practice literature has so far paid little attention to these problems. Little information on the practicalities of sampling was found in the literature. A 'medline' search, using the key words 'random' in combination with 'research design', 'epidemiological methods' and 'selection bias' produced only a handful of articles about the practical performance of random sampling $1,2,3,4$. None of the methods described seemed suitable for our project.

In the present study, sampling was done by means of a purpose-built 'random selector' and a simple protocol. Our motivation for this, as well as details on the method, are discussed below. The patient data thus collected can be used to obtain some idea of the reliability of the method used. 


\section{Methods}

\section{Setting}

The study was held among 16 general practitioners. The study population was defined as all persons registered in the practice, aged 16 and over, who visited the surgery at least once within the specified one-year period.

Patient data were collected by means of a questionnaire, which included a list of screening questions for problem drinking. After oral and written 'infornned consent' had been obtained, the GP gave the list to the patient to take home. The results of the screening were used as the standard for the presence or absence of problem drinking.

The GP used a registration form to record all consultations with the patients included in the study over a one year period. 'Reasons for encounter' (RFEs) and 'diagnoses/evaluations' (Es) were coded using ICPC codes'.

Within the study population, four categories of patients could be distinguished: those known by their GP to have a drinking problem and showing a positive screening on the questionnaire (group 1), those with a drinking problem unrecognized by their GP (group 2), and those without a drinking problem (group 3). Group 4 consisted of those who were known by their GP to have a drinking problem, but who did not show a positive score on the screening questionnaire (see Table 1).

\section{Methodological background}

General practice registration systems $s^{6,7}$ have shown that ca. $1 \%$ of the patient population are known to their GPs as problem drinkers. The literature further shows that screening would lead to at least $10 \%$ of patients being recognized as problem drinkers $8,9,10,11$.

Assuming a prevalence of $10 \%$ for problem drinking and a number of 200 patients in group 1 , groups 2 and 3 would include 1800 and 18000 patients respectively (see Table 2 ). The prior estimation of the size of group 4 is that it is small, assuming that the general practitioner makes few false positive diagnoses.

One of the striking aspects of table 2 is the unequal contents of the cells. Against 200 known problem drinkers there are 19800 persons judged by the GP not to be problem drinkers. A better balance between these figures could be achieved by taking a sample from the latter category.

Other arguments also favoured the taking of a sample from this subpopulation. In view of the nature of the data collection process, it was necessary that the 
GPs themselves recruited patients for the study and subsequently recorded these patients' consultations themselves. If no sample was taken from the population, this would imply that the GPs would have to provide information about the research project to all patients who visited their surgery for the first time during the one-year observation period. This would mean about 5 minutes of explanation about the study and the questionnaire for every new patient included in the study, since in a survey-type study, a high level of patient motivation, which has to be stimulated by the GP, is vital for a high response rate.

In a pilot study we found that responses exceeding $90 \%$ were feasible. This is much higher than the response to a similar questionnaire sent by post, which yielded a $60 \%$ response. In addition, the study would require all consultations of the patients included to be recorded over the one-year study period. The level of detail of the data to be collected precluded the use of the GPs' standard records. Hence, this would mean an extra registration system for nearly all consultations involving persons aged over 15 .

This would seem to require an unacceptably high amount of effort from the GPs.

The second argument favouring the taking of a sample is that a valid statement on the differences between groups 1,2 and 3 does not require group 2 to be 9 times the size of group 1 and group 3 to be 9 times the size of groups $1+2$. The power of the study would not be appreciably raised, while inaccuracies on the part of the GPs and a lower patient response might result in a lower validity. Moreover, ethical considerations dictated that the study should not include more patients than is strictly necessary.

The above considerations led to the decision to take a random sample from groups 2 and 3.

\section{Sampling requirements}

Since the present study concerned patients visiting the surgery during the study period, the sampling was done at the first surgery visit within the study period. Having the procedure carried out by the GP during the consultation would make it clear to the patient that a random inclusion procedure was being used. It seemed important, especially in view of the alcohol-related subject of the study, that the patients should be aware of the random nature of the sampling. In addition, the compliance of the GPs in following the study protocol might be enhanced by their being reminded of the study at each consultation, since they had to use the sampling procedure each time. This should lead to a study 
routine which minimized the chance of them forgetting to include new patients.

Hence, the sampling procedure had to require a minimum investrnent of time on the part of the GP during the consultation, and its random nature had to be clear to the patients.

Since the sampling procedure was to be implemented during each patient's first consultation, it had to be clear at follow-up consultations whether the patient had been included in the study or not, in order to prevent frequent visitors from having a higher chance of being included.

The sample size had to be such that it would require an acceptable amount of effort from the GPs, and yield sufficient numbers of patients for groups 2 and 3.

Taking 1 in 10 samples from groups 2 and 3 would mean that the expected size of group 2 would be of the same order of magnitude as that of group 1 (see Table 3).

If 30 persons a day visited the surgery, an average of 3 would be included in the sample. This means that the chance that more than 6 patients a day were be included in the study would be $2.6 \%$.

Although a larger sample would yield a higher precision, this would probably be at the expense of the quality of the implementation of the study, because of the higher workload for the GPs.

\section{Random selector}

The sampling was done by means of a specially designed 'random selector' (Fig. 1), which is able to take random samples. The instrument shows, at random, a red or a green light after a button has been pushed. Sample sizes can be set at between 1:2 and 1:100. The 'random selector' is powered by a 9 volt battery, which has to be changed every 3 months at normal use. Reliability tests at the 1:10 setting showed the sample size to be highly reliable. For a random sample of 825 cases, 8279 sampling procedures were needed, a deviation of less than $0.3 \%$.

The 'random selector' was applied in the present study, using the following procedure. If a known problem drinker visited the surgery, this patient was included in the study, and his or her file card was marked with a blue sticker. If a patient was not known to the GP as a problem drinker, the GP pushed the button of the 'random selector'. If the green light flashed, this meant that the patient was not to be included in the study, and the GP marked the file card with a green sticker. If the red light came on, the patient was included in the 
study, and his or her file card was marked with a red sticker. Hence, it was immediately clear at a follow-up consultation whether or not the patient had been included in the study.

The reliability of the data collection was tested at the end of the data collection period by checking the patient files to see which of the consultations of the included patients had actually been recorded by the GP for the purpose of the study. Non-recorded consultations could be divided into consultations before the inclusion date and those after that date. Missing consultations before the inclusion date were those in which the GP did not perform the sampling procedure. Missing consultations after the inclusion date were those the GP forgot to record for the study among patients already included. The number of unrecorded consultations gave some idea of the GP's compliance with the protocol. As far as possible, the evaluations of those consultations not recorded for the study were coded according to the ICPC. These codes could be compared with those of the consultations which were recorded, in order to establish a possible selective loss of certain types of consultations. 


\section{Results}

There were hardly any practical or technical problems. The method proved to be technically reliable; only 1 of the 16 participating physicians had to have the battery of his random 'selector' changed (twice) before the expected date of expiry. No defects occurred. All GPs were satisfied about the method: it required little time and was quickly integrated into their surgery routine. Patients did not object to the method, since it could be made clear to them that the inclusion or exclusion depended purely on chance.

In all, 1537 persons were included in the study (see Table 4). Of the 153 persons known to their GPs as problem drinkers, 122 returned a questionnaire (response rate $=80 \%$ ), while 1283 of the remaining 1384 patients responded (response rate $=93 \%$ ). This resulted in 86 persons being included in group 1 and 82 persons in group 2.

After the observation period, the file cards of 1473 patients could be retrieved ( 33 cards were missing, 31 patients had moved). A total of 2210 consultations had not been recorded, 584 before inclusion into the study and 1626 after inclusion. The total number of consultations recorded after inclusion by the GPs for those patients whose file cards could be retrieved was 2763 . This means that $2763 / 2763+1626=63 \%$ of the follow-up consultations were recorded.

For the 1384 persons in groups 2 and 3, 1327 file cards could be inspected ( 31 were lost, 26 patients had moved). The number of consultations not recorded for these categories before inclusion into the study was 507. This means that a sample was taken in $1327 / 1327+507=72 \%$ of the cases in which the protocol required this to be done.

Table 5 shows the 10 most frequent diagnoses for the consultations recorded for the study and for those not recorded for the study.

Of the ten most frequent diagnoses in the two categories, eight corresponded. Furthermore, the order was largely the same in the two categories. Diagnoses P76 and X84 were underrepresented in the recorded consultations, while W11 and P15 were overrepresented in these consultations. 


\section{Discussion}

In practice, sampling by the GP during surgery, using the 'random selector', proved to work well. Patients could be shown the random character of the procedure, while the extra workload for the GP was limited. The fact that, both before and after the inclusion date, consultations with patients who had been included were not always recorded, shows that the GPs did not always comply with the protocol. During the period of data collection, it was impossible to check whether the sampling procedures were always correctly implemented. During the collection of data on the basis of numbers of patient contacts in a specified period it cannot be monitored how often a GP forgets to apply the sampling procedure. If few patients are included in the study during a particular period, this may be due to chance, or it may be due to the fact that the GP has forgotten to implement the sampling procedure for a number of patients. Some idea of this could be obtained afterwards by checking the file cards of the patients included. One possible way of monitoring the GPs during the study would have been a log of the sampling procedures, to be kept automatically by the 'random selector'.

The total population consisted of 1537 instead of the expected 2000 persons. As expected, the proportion of known problem drinkers was 1\%; as a result of the sampling procedure, this figure became $10 \%$ of 1537 patients (Table 4). The abovementioned figures show that the numbers of patients ultimately included were smaller than had been estimated beforehand. This can be partly explained from the fact that no sample was taken in $28 \%$ of the consultations for which the protocol demanded it.

The study population was also reduced as a result of the rate of non-response to the questionnaire. A number of patients disappeared from the population because they died or moved. In accordance with prior estimations, the eventual numbers of patients in groups 2 and 3 were roughly the same, but the total numbers were smaller than expected. For reasons mentioned above, a larger sample size was consciously avoided. This means that larger numbers of patients can only be obtained by asking more GPs to participate.

A closer analysis of the non-recorded consultations shows great similarity between these consultations and those which were recorded for the study. The similarity is, however, not perfect. P76 (depressive disorder) and X84 (vaginitis/vulvitis) were underrepresented. It is possible that the had GP hesitated to implement research procedures in such consultations. The fact that P15 (chronic alcohol abuse) was overrepresented among the recorded consultations 
is an effect of the study design, which resulted in the active selection by GPs' of problem drinkers. The frequent recording of W11 (oral contraception) remains unexplained. If there was selective recording, it has played a minor part.

The sampling method described here can be used in any study in which samples have to be taken or in which patients have to be randomly assigned. The method would seem especially suitable if random sampling has to be done in a field situation by somebody else than the chief researchers. The number of tools required for random sampling is limited to 1 device, which is easily transportable and technically reliable. 


\section{References}

1. Le CT, Lindgren BR. Randomization using package programs. Comput Biomed Res 1988;21:593-6.

2. Borsini F. Randomization Program for Apple IIe Computer. Brain Res Bull 1985;15:279-81.

3. Wielgosz AT, Nicholls E, Biro E, MacWilliam L, Mao Y. Random digit dialing. Can J Public Health 1987;78:201-2.

4. Mukhopadhyay SK, McKeever PE, Greensberg HS, Junck L, Chandler WF, Ensminger W. Random sampling by glitter drop method. Life Sci 1990;46:50712.

5. Lamberts $\mathrm{H}$, Wood $\mathrm{M}$ (eds). ICPC. International classification of primary care. Oxford University Press, 1978.

6. Lamberts $\mathrm{H}$, Brouwer H, Groen ASM, Huisman H. Het transitiemodel in de huisartspraktijk. Supplement May lst 1987 on ICPC rubrics P15, P16. Huisarts \& Wet 1987;30:105-13.

7. Morbidity figures from general practice, data from four general practices 19781982, Nijmegen University Department of General Practice, Nijmegen 1985.

8. Leckman AL, Umland BE, Blay M. Prevalence of alcoholism in a family practice center. J Fam Pract 1984;18:867-70.

9. Nicol FE, Ford MJ. Use of the Michigan Alcoholism Screening Test in general practice. J Roy Coll Gen Pract 1986;36:409-10.

10. Woodall HE. Alcoholics remaining anonymous: resident diagnosis of alcoholism in a family practice center. J Fam Pract 1988;26:293-6.

11. Wallace $P$, Haines A. Use of a questionnaire in general practice to increase the recognition of patients with excessive alcohol consumption. Brit Med J 1985;290 :1949-53. 
Table 1:

GP PD +/-: problem drinkers/not problem drinkers according GPs. Screening PD +/-: result of problem drinking screening test.

\begin{tabular}{l|c|c|l} 
& SCREENING PD + & SCREENING PD - & \\
\hline GP PD + & group 1 & group 4 & \\
\hline GP PD - & group 2 & group 3 & \\
\hline & & &
\end{tabular}

Table 2: theoretical number of persons without random sampling $<$ = expected small number

\begin{tabular}{l|c|l|l} 
& SCREENING PD + & SCREENING PD - & \\
\hline GP PD + & 200 & $\ll$ & 200 \\
\hline GP PD - & 1800 & 18000 & 19800 \\
\hline & 2000 & 18000 & 20000
\end{tabular}

Table 3: theoretical number of persons after random sampling $<<=$ expected small number

\begin{tabular}{l|c|c|l} 
& SCREENING PD + & SCREENING PD - & \\
\hline GP PD + & 200 & $\ll$ & 200 \\
\hline GP PD - & 180 & 1800 & 1980 \\
\hline & 380 & 1800 & 2180
\end{tabular}


Table 4: eventual number of persons included in the study.

\begin{tabular}{|c|c|c|c|c|}
\hline & SCREENING PD + & SCREENING PD - & Response & Admitted to study \\
\hline GP PD + & 86 & 36 & 122 & 153 \\
\hline GP PD - & 82 & 1201 & 1283 & 1384 \\
\hline 8 & 168 & 1237 & 1405 & 1537 \\
\hline
\end{tabular}


Table 5: the 10 most frequent diagnoses in recorded and non-recorded consultations, in order of decreasing frequency.

recorded consultations

non-recorded consultations

\begin{tabular}{|c|c|c|c|}
\hline K86 & hypertension & K86 & hypertension \\
\hline L18 & $\begin{array}{l}\text { muscle pain, myalgia, fibro- } \\
\text { sitis }\end{array}$ & L99 & $\begin{array}{l}\text { other diseases musculos- } \\
\text { keletal system. }\end{array}$ \\
\hline 74 & upper respiratory infection & L18 & $\begin{array}{l}\text { muscle pain, myalgia, fibro- } \\
\text { sitis }\end{array}$ \\
\hline 99 & $\begin{array}{l}\text { other diseases musculoskeletal } \\
\text { system }\end{array}$ & R74 & upper respiratory infection \\
\hline 11 & oral contraceptive & P76 & depressive disorder \\
\hline 88 & $\begin{array}{l}\text { contact dermatitis/other ecze- } \\
\text { ma }\end{array}$ & R78 & acute bronchitis \\
\hline 78 & acute bronchitis & S88 & $\begin{array}{l}\text { contact dermatitis/other } \\
\text { eczema }\end{array}$ \\
\hline 75 & sinusitis & R75 & sinusitis \\
\hline & $\begin{array}{l}\text { other injury musculoskeletal } \\
\text { system }\end{array}$ & X84 & vaginitis/vulvitis \\
\hline 15 & chronic alcohol abuse & L81 & $\begin{array}{l}\text { other injury musculo skele- } \\
\text { tal system }\end{array}$ \\
\hline
\end{tabular}




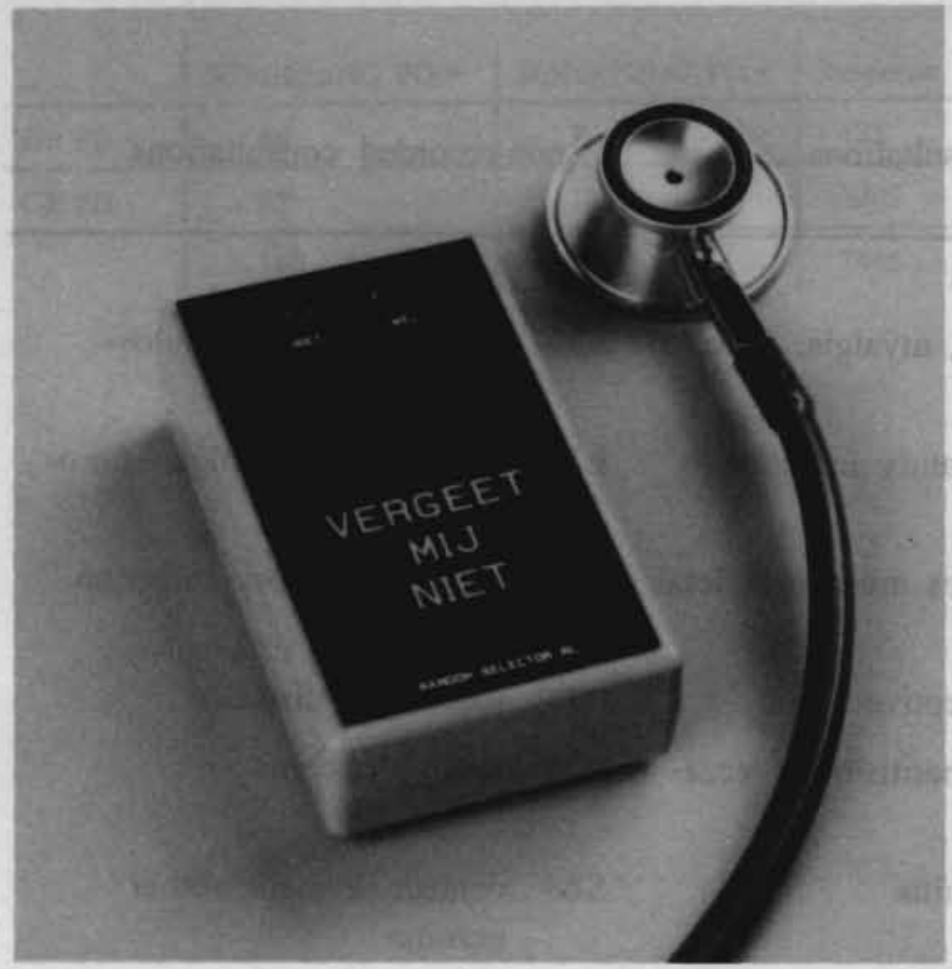

Figure 1: 'Random selector' with the text 'forget-me-not'.

Acknowledgement:

We would like to thank P. Bungenstock, Instrument Department, for the design and construction of the 'random selector'. 


\section{Chapter 4}

\section{Problem drinking in a general practice population:}

the construction of an interval scale for severity of problem drinking

Published in the Journal of Studies on Alcohol 1994;55:466-70.

M. Cornel, MD *

R.A. Knibbe, $\mathrm{PhD}$ **

W.M. van Zutphen, $\mathrm{MD}, \mathrm{PhD}$ *

M.J. Drop, $\mathrm{PhD}$ **

* Department of General Practice, University of Limburg

** Department of Medical Sociology, University of Limburg

Correspondence:

M. Cornel

Department of General Practice

University of Limburg

P.O. Box 616

$6200 \mathrm{MD}$ Maastricht

The Netherlands 


\section{Abstract}

The main aim of this paper is to describe the construction of an interval scale measuring the severity of problem drinking among patients of general practitioners. A questionnaire, including the existing screening instruments CAGE, SMAST, a shortened version of SAAST and some additional items on alcohol-related problems, was presented to three categories of patients: those who, according to the general practitioner, were not problem drinkers (group 1 ), those who perhaps were (group 2) and those who were known by the general practitioner to be problem drinkers (group 3).

According to the Classical Test Theory, the three existing screening instruments and the combination of all questions form a reliable scale. Advanced scaling techniques were applied to select the best items for the construction of an interval scale.

These analyses showed that 18 of the 28 questions in the complete screening list fitted in a unidimensional Rasch scale. These questions can be used to estimate the severity of problem drinking. An interval scale is attractive for research purposes, since no information is lost by dichotomization. Such a scale allows specification of the level of problem drinking at which correlations with other factors, whether as a cause or as an effect, can be found. The scale could also be a help to general practitioners in taking referral decisions. In more specialized settings it can be used to assign patients to various treatments.

Key words: Problem drinking, Family Practice, Screening, Questionnaire, Validation. 
The per capita alcohol consumption in the Netherlands rose by more than $300 \%$ between 1960 and $1980^{1}$. Since this period, the consumption level has more or less stabilized. Prevalence estimates from representative Dutch population surveys show that about $10 \%$ of the population can be identified as problem drinkers ${ }^{2}$. Morbidity figures from general practice indicate that $1 \%$ of the general practice population are diagnosed as problem drinkers ${ }^{3}$. The gap between population survey estimates and general practitioners' (GPs) estimates is only partly explained by a possibly more restrictive definition of problem drinking among general practitioners. It appears that a substantial proportion of the problem drinkers are not recognized by their GPs ${ }^{4}$.

Dutch population surveys also indicate that male problem drinkers up to the age of 30 visit their GPs more often than a comparable group ${ }^{2}$. Patients known to the GP as problem drinkers have been found to have a doctor contact rate almost twice that of a control group. They also showed more frequent social, marital, smoking and accident-related problems, as well as psychosocial and gastrointestinal disorders 5 .

Studies of problem drinkers in general practice populations have so far been largely restricted to a selection of problem drinkers, namely those known as such to the $\mathrm{GP}^{6}$. It is questionable whether data from known problem drinkers also apply to those not known by the GP to be problem drinker.

Detection by the GP can be done with a validated screening instrument. However, the systematic use of screening instruments on large parts of the patient population does not fit in with the working style of the GP. Therefore, our study aimed to establish whether identified problem drinkers, unidentified problem drinkers and a control group of non-problem drinkers differed in consultation rates, reasons for encounter, evaluation (diagnoses) and background variables. Should unidentified problem drinkers be found to differ from the other groups on one or more of these points, detection would be greatly facilitated because the GP could than select patients with a greater risk of problem drinking.

A prerequisite for such a study is a reliable instrument for detecting unidentified problem drinkers. The literature describes different screening methods varying from biochemical parameters to extensive interviews. In our study we used self-administered questionnaires, which are more reliable than biochemical parameters ${ }^{7}$ and less time-consuming than personal interviews ${ }^{8}$. 
Most of the existing instruments have been validated in clinical populations. Proper validation of these instruments for general practice populations has never taken place.

We decided to choose the three most commonly cited instruments, CAGE ${ }^{9}$, SMAST $^{10}$ and a shortened version of SAAST ${ }^{11}$. This choice allows comparisons to be made with other studies. Our intention was to construct an interval scale that would measure the seriousness of problem drinking. Fixed cut-off points to define problem drinking are always arbitrary. An interval scale would allow one to specify at which level of severity problem drinkers differ from a control group.

We did not use the existing scales measuring severity of alcohol dependence such as the Severity of Alcohol Dependence Questionnaire (SADQ) ${ }^{12}$ and the Alcohol Dependence Scale (ADS) ${ }^{13}$, mainly for two reasons. First, these questionnaires would discourage patients from the general practice population from filling out the questionnaire, since questions refer to heavy drinking. Secondly, our aim was to measure seriousness of problem drinking in patients not recognized as problem drinkers by GPs. These patients differ strongly from severely addicted problem drinkers in the clinical populations where the above-mentioned instruments were validated.

In this article we first present the results of the construction of the abovementioned interval scale, with the help of a Rasch analysis, a logistic model based on the Guttman scale. Secondly, to indicate the extent to which this new instrument differs from the existing screening instruments, we present prevalence figures based on CAGE, SAAST, SMAST and the 'Rasch scale' with a fixed cut-off point, as well as the agreement between the different instruments. As a first indication of the external validity of the new scale, correlations with consumption level and social problems will be presented. 


\section{Methods}

Over a period of one year 16 general practitioners, with a total patient population of 32,000 persons, were involved in the study, which took place in the southern part of the Netherlands, in both urban and rural parts of the country. The target group included patients aged 16 and over, who attended surgery hours. All known problem drinkers were admitted to the study, as well as a random selection of one in ten patients (Cornel et al. submitted for publication) who, according to the GPs' assessment, were not or only possibly problem drinkers. The sampling was done by the general practitioners themselves, during surgery hours, using a purpose-built 'random selector'. Refusal rates, according to the GPs' report, were less than $1 \%$. After one year, 1537 patients (1269 non-problem drinkers according to the GPs' assessment, 115 possible problem drinkers according to the GPs' assessment and 153 problem drinkers according to the GPs' assessment) were admitted to the study. The overall response was $92 \%$. The response among recognized problem drinkers and patients classified by the GP as possible problem drinkers was lower ( $80 \%$ and $86 \%$ respectively).

These selected patients received a questionnaire from their doctor containing questions about social background variables, drinking, smoking, drug use, physical and social wellbeing and level of alcohol consumption. It comprised the three screening instruments CAGE, SMAST and SAAST, and some additional screening questions. The additional questions referred to more positive aspects of drinking. Only people who had consumed any alcoholic beverages in the past year had to answer the questions about alcohol consumption and alcohol-related problems.

Scaling techniques were used to decide which of the three screening instruments, or what combination of items, would form an interval scale and thus could be used for our study. The first step entailed calculating Cronbach's Alphas, a measure of the reliability of a scale, for each of the three screening instruments separately and for the combination of all iterns on alcohol-related problems. The second step was a Rasch analysis, a sophisticated scaling technique which aims to establish the unidimensionality of a set of questions $^{14,15,16}$. The Rasch model is a stochastic model based on the Guttman scale. The latter is based on the following principle: there is a group of persons with a property to be measured, and a group of questions that measures aspects of this property. If the Guttman scale is perfect, $n+x$ 
questions can be ordered in such a way that all persons with score $\mathbf{n}$ score positively on the $n$ easiest questions ('easy' meaning that the aspect occurs more frequently). With a score $n+1$ the same $n$ questions are scored + the next easiest question. This is a very stringent requirement for unidimensionality, which does not allow for biological variation. The Rasch model has the same characteristics but, unlike the Guttman scale, does allow for random variation. The Rasch characteristics of a scale are tested by means of three tests (PML computer program). The first test is the Molenaar-U test. For each item, the differences between estimated and observed scores, both within score-groups and across score-groups, are tested. According to the Rasch model, the probability of scoring an item rises homogeneously with a higher score. This test can successively remove the worst fitting items. The second test is the Anderson test (A-ICCSL), which performs a model estimation on the basis of low and high scorers on the instrument. If a set of questions is unidimensional, the parameter estimations are the same for the low and high score groups. This test can also successively remove items.

The Martin Loff Chi square test (ML-ICCSL) assesses the difference between estimated and observed numbers of persons per score group over items and gives a Chi-square for the entire set of items.

On the basis of the results of these analyses a decision can be made as to which set of questions best fits the Rasch model.

These tests are rather strict in comparison to the Cronbach's alpha used in Classical Test Theory. If these tests give a non-significant result, the items involved can be positioned on a unidimensional scale and ordered according to the degree of 'difficulty'. This not only means that the score on this scale is a good indicator of the severity of problem drinking, but, because the items are rank-ordered in terms of 'difficulty', each separate item also indicates which set of particular symptoms a patient is likely to have.

The Rasch model was used to check the homogeneity of the three existing instruments, CAGE, SMAST and SAAST. Subsequently, the entire set of items was considered and the ill-fitting items were successively removed using the Molenaar- $U$ test as a criterion. A Rasch scale should not fail any of the three above-mentioned tests after the removal of ill-fitting questions.

It was only for purposes of comparison between CAGE, SMAST and SAAST on the one hand and the Rasch scale on the other, that a cut-off point for the latter was chosen. We computed prevalence figures for the three groups (nonproblem drinkers, possible problem drinkers and known problem drinkers) and the overall prevalence figures were estimated, accounting for the different 
sampling fractions. The agreement between the instruments for the above three groups was evaluated by means of Cohen's kappa. External validity of the Rasch scale was investigated by a regression analysis with consumption level (weekly recall method) and a scale on chronic social problems. Chronic social problems were measured with the 'Longtern Difficulties Questionnaire', a 12 item list on several social problems such as those concerning work, school, finance, and relationships ${ }^{17}$. A problem may be small, intermediate or big, scoring 1, 2, and 3 points respectively. The sum-score of all problems is a measure of social problems (Cronbach's Alpha $=0.66$ ). 


\section{Results}

Cronbach's Alpha values for CAGE, SMAST, SAAST and a combination of all items were $0.75,0.87,0.84$ and 0.93 respectively. According to Classical Test Theory all questions combined form a reliable scale.

The Rasch analysis showed that CAGE, SMAST and SAAST were not Raschhomogeneous. All tests gave significant p-values, indicating deviations from the model. Neither did the combination of all questions fulfill the requirements of the Rasch model.

On the basis of the Molenaar-U test, items were removed from the entire list. After removal of 10 items, the Molenaar-U test, the Anderson test and the Martin-Loff Chi-square test only yielded non-significant p-values, which indicates that the requirements of the Rasch model were met. The selected screening questions, arranged in order of increasing difficulty, are presented in table 1 . The more difficult the items, the less frequently they are scored positively. This Rasch-homogeneous scale implies that someone who scores positive on the third easiest item (Do close relatives ever worry......) will probably also have answered affirmatively to the first two items. With one exception (item 2: drinking to forget worries) the first 5 items indicate social or personal reactions to alcohol consumption. The items numbered 6-11 are the more classical symptoms of excessive drinking, including two items (items 8/9: Stop when you want to/Stop without a struggle) that give a more direct indication of loss of control. With one exception (item 14: hidden drinking) the most difficult items indicate health (e.g. hospitalization) and social consequences (e.g. neglecting obligations) and dependence (e.g. drinking in order to work better).

To compare the groups identified by the different screening instruments, we took the cut off points advised in the literature for the existing instruments (CAGE, MAST and SAAST) and a cut off point of 3 for the Rasch scale. Table 2 presents the response and prevalence figures for the categories of nonproblem drinkers, possible problem drinkers and known problem drinkers. Seven people in the group of 'problem drinkers according to the GP' did not score on one instrument, since they reported no alcohol consumption in the previous year. Response decreased if the GP was more certain that problem drinking was involved. There were no significant differences in gender, age or consultation rates between response and non-response in the three categories of patients.

Population figures were estimated, taking into account the one in ten random 
sample fraction of the groups of non-problem drinkers and possible problem drinkers. SAAST and SMAST gave about the same prevalence figures, while the CAGE figure was slightly higher and the Rasch scale with the abovementioned cut-off point was intermediate between the two.

The Kappas of the Rasch scale with CAGE (0.76), SMAST (0.76) and SAAST (0.82) are fairly high. Apparently, all these instruments identify a similar group of patients as problem drinkers.

The linear regression of the Rasch score with consumption level and score on the scale of chronic social problems resulted in significant $(p \leq 0.001)$ regression lines with a correlation of 0.64 for consumption level and a correlation of 0.34 for chronic social problems. Correlations of the CAGE, MAST and SAAST with consumption level $(0.52,0.63$ and 0.63 respectively) and chronic social problens $(0.29,0.32$ and 0.30 respectively) tended to be slightly lower. 


\section{Discussion}

The values of Cronbach's Alpha for the three instruments separately and for all items together were high enough to accept each of the combinations of items as a scale. Neither the separate instruments CAGE, SMAST and SAAST, nor the combination of all items were Rasch-homogeneous. This means that they do not allow conclusions about the severity of problem drinking.

The combination of 18 questions formed a perfect Rasch scale. These items can be rank ordered according to 'difficulty' on a unidimensional scale. In other words, a person with a total score of 4 has the greatest chance to score positive on the first 4 items. The severity of problem drinking is reflected by the total score on the instrument. Roughly speaking, the 5 items most commonly admitted to were found to indicate mainly social or personal reactions to problem drinking. The next 6 items refer to the more classical symptoms of excessive drinking, including loss of control. The most difficult items deal mainly with dependence on alcohol and serious health and social consequences of drinking. Since the Rasch model is a stochastic model based on the Guttman scale, it is likely that someone who admits to an item indicative of serious problem drinking, such as drinking in order to work better, will also admit to the preceding, 'easier' items. It is tempting to interpret this sequence of social and personal reactions to drinking, symptoms of drinking and finally dependence and serious health and social consequences as stages in a process. Our data, however, do not allow such conclusions, since we have cross-sectional data.

Although the scale was not developed primarily for the GP to use during surgery hours, the definite rank-order in terms of 'difficulty' could make it useful in general practice. The GP might select one item and be fairly certain that the patient will score positive on other, easier items. The severity of problem drinking may help the GP to decide whether referral to a specialized treatment agency is indicated. In more specialized settings the differentiation for severity of problem drinking could indicate the intensity of treatment. The instrument could also be used for treatment outcome studies. With respect to our research question, this scale allows one to specify at what level of severity problem drinkers differ from non-problem drinkers in, for example, consultation rates or diagnosis.

To evaluate the Rasch scale against the existing screening instruments CAGE, SMAST and SAAST, a cut-off point of 3 or more positive answers was 
chosen. This allows for prevalence figures to be determined with the Rasch scale. Since responses were lower in the groups of known problem drinkers and possible problem drinkers, it seems that problem drinkers are less willing to participate in a study about problem drinking. This might result in lower prevalence figures. The correspondence between the four instruments were fairly good. This is not surprising, since they partly comprise the same questions. CAGE produces the highest prevalence figures. This is plausible, since its limited number of questions allows less specificity compared with the other, more extensive instruments. It could, in principle, be more sensitive than the other instruments, but prevalence figures in the group of known problem drinkers do not support this assumption. The Rasch scale measures the highest prevalence in the group of possible problem drinkers and that of known problem drinkers, although it does not yield the highest figures in the group of people regarded by their GPs as non-problem drinkers. We correlated the Rasch scale with two external variables which were not part of the instrument, consumption level and chronic social problems. The correlations were significant, as expected: a higher score on the Rasch scale is related with a higher consumption level $(r=0.64)$ and more chronic social problems $(r=0.34)$. These outcomes give a first indication of the external validity. The existing scales CAGE, SAAST and SMAST tend to have somewhat lower correlations with these external variables.

Research purposes may include optimal separation of groups or a differentiation of the study population into more than two groups, possessing a defined measure of a certain property. The Rasch scale can separate the study population at interval level, which makes it possible to specify at what level of problem drinking correlations with other factors, whether as a cause or as an effect, can be found. 


\section{References}

1. Commodity Board for Distilled Spirits. World Drink Trends. NTC Publications Ltd, United Kingdom 1991.

2. Garretsen HFL, Knibbe RA. Two Dutch surveys on problemdrinking. Med Sci Law 1985;4:265-8.

3. Lamberts $\mathrm{H}$, Brouwer $\mathrm{H}$, Groen ASM, Huisman H. Het transitiemodel in de huisartspraktijk. Supplement May 1st 1987 on ICPC rubrics P15, P16. Huisarts \& Wet. 1987;30:105-13.

4. Cornel M, Van Zutphen WM. Recognition of problem drinkers and the role of the general practitioner. Can Fam Physician 1989;35:1167-9.

5. Buchan IC, Bucki EG, Deacon GLS, Irvine R, Ryan MP. Problern drinkers and their problems. J Roy Coll Gen Pract 1981;31:151-3.

6. Rush B, Brennan $M$. Is the health profile of problem drinkers different from that of other patients? J Fam Pract 1990;31:42-6.

7. Beresford TP, Blow FC, Hill E, Singer K, Lucey MR. Comparison of CAGE questionnaire and computer-assisted laboratory profiles in screening for covert alcoholism. Lancet 1990;336:482-5.

8. Rolnick SJ, Gross CR, Garrard J, Gibson RW. A comparison of response rate, data quality, and costs in the collection of data on sexual history and personal behaviors. Mail survey approaches and in-person interview. Am J Epidemiol 1989;129:1052-61.

9. Mayfield D, McLeod G, Hall P. The CAGE questionnaire: Validation of a new alcoholism screening instrument. Am J Psychiat 1974;131:1121-3.

10. Selzer ML, Vinokur A, Van Rooijen L. A self-administered Short Michigan Alcoholism Screening Test (SMAST). J Stud Alcohol 1975;36:117-26.

11. Davis LJ, Hurt RD, Morse RM, O'Brien PC. Discriminant analysis of the SelfAdministered Alcoholism Screening Test. Alcohol Clin Exp Res 1987;11:269-73.

12. Stockwell T, Hodgson R, Edwards G, Colin T, Rankin H. The development of a Questionnaire to measure severity of alcohol dependence. Br J Addict 1979;74: 79-87.

13. Skinner HA, Allen BA. Alcohol Dependence Syndrome: Measurement and validation. J Abnorm Psychol 1982;91:199-209.

14. Wright BD, Stone MH. Best Test Design, Chicago: Mesa Press, 1979. 
15. Gustafsson JE. The Rasch model for dichotomous items: Theory applications and a computer program. Report no. 63. Institute of Education, University of Göteborg, Fack S-431, 20 Mölndal, Sweden, 1977.

16. Molenaar IW. Some improved diagnostics for failure of the Rasch model. Psychometrica 1983;48:49-72.

17. Hendriks AAJ, Ormel J, Van de Willige G. Langdurige moeilijkheden gemeten volgens zelfbeoordelingsvragenlijst en semi-gestructureerd interview. Een theoretische en empirische vergelijking. Gedrag en Gezondheid 1990;18:273-83. 
Table 1: Questions in order of increasing 'difficulty' (frequency of positive scores).

1: Have you ever felt the need to cut down on your drinking? (260)

2: Do you ever drink to forget your worries? (157)

3: Do close relatives ever worry or complain about your drinking? (118)

4: Have you ever been told by a doctor to stop drinking? (116)

5: Have people annoyed you by criticizing your drinking? (105)

6: Do you ever have a few drinks before you go to a party? (95)

7: Do you ever skip meals when you are drinking? (94)

8: Are you (always) able to stop drinking when you want to? (92)

9: Can you stop drinking without a struggle after one or two drinks? (89)

10: Have you ever had a drink first thing in the moming to steady your nerves or get rid of a hangover? (64)

11: Do you ever drink in the morning? (63)

12: Have you ever been in hospital because of drinking? Was drinking part of the problem that resulted in your hospitalization? (46)

13: Have you ever gone to anyone for help about your drinking? (45)

14: Did you ever hide your drinking? (41)

15: Do you ever drink to optimize your thinking? (35)

16: Do you ever drink in order to work better? (24)

17: Have you ever neglected obligations, your family or your work for two or more days in a row because you were drinking? (24)

18: Have you ever lost a job because of your drinking? (14) 
Table 2: Prevalence of problem drinking in the three groups and prevalence estimated for the population from which the sample was taken, accounting for the 1 in 10 sample in groups 1 and 2 .

$\begin{array}{llllllll}\text { group } & (\mathrm{n}) & \text { response } & \mathrm{n} & \mathrm{CAGE} & \text { SMAST } & \text { SAAST } & \text { RASCH } \\ 1^{*} & 1269 & 93 \% & 1184 & 6 \% & 4 \% & 4 \% & 5 \% \\ 2^{\dagger} & 115 & 86 \% & 99 & 23 \% & 21 \% & 23 \% & 25 \% \\ 3^{\ddagger} & 153 & 80 \% & 122 & 64 \% & 64 \% & 65 \% & 71 \% \\ & & & & & & & \\ \text { population } & 92 \% & 8 \% & 6 \% & 6 \% & 7 \%\end{array}$

1: non-problem drinkers according to the general practitioner

2: possible problem drinkers according to the general practitioner

3: problem drinkers according to the general practitioner 


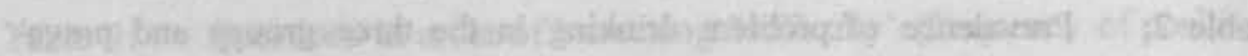

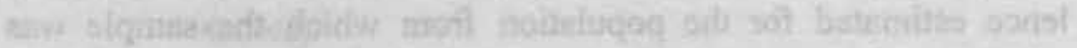

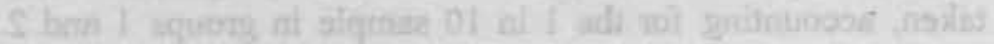

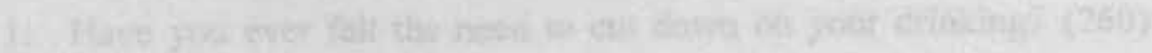

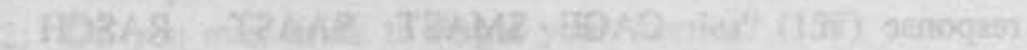

(a) ryia

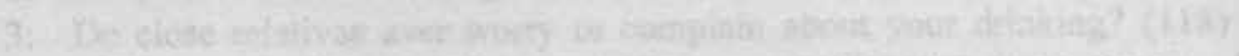

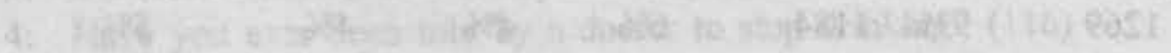

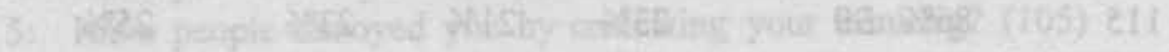

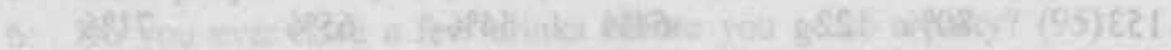

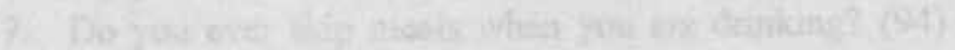

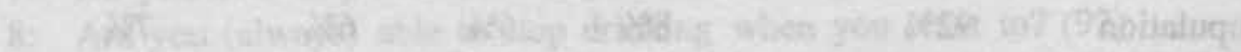

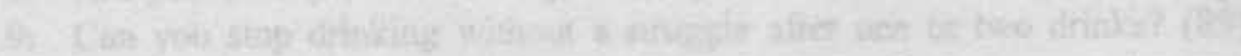

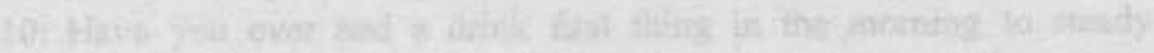

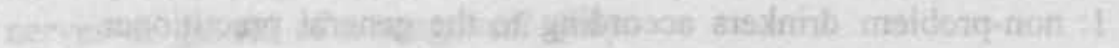

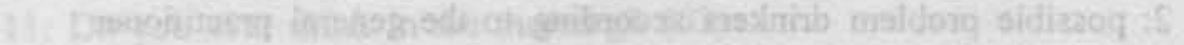

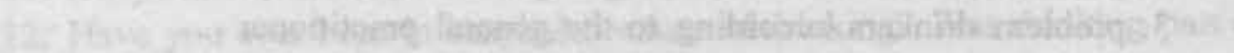

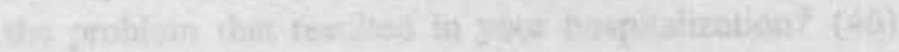

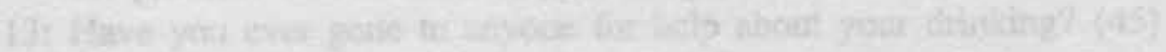

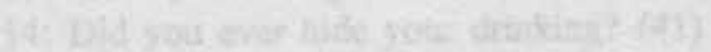

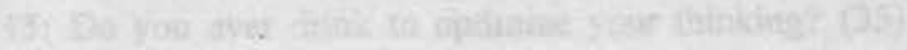

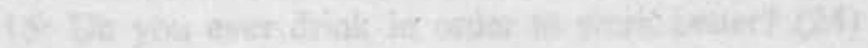

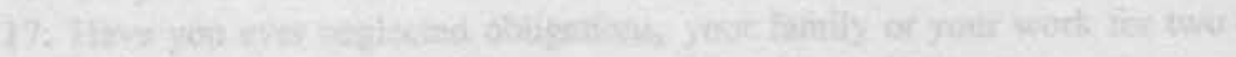

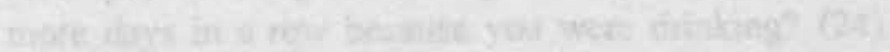

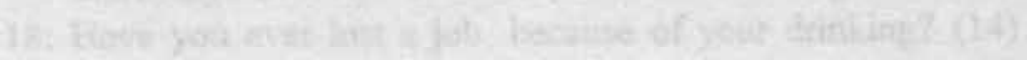




\section{Chapter 5}

\section{Predictors for hidden problem drinkers in general practice}

Submitted for publication.

Michiel Cornel, MD, General Practitioner *

Ronald A. Knibbe, PhD, Medical Sociologist ${ }^{\dagger}$

André Knottnerus, PhD, General Practitioner *

Alex Volovics, $\mathrm{PhD}$, Statistician

Maria J. Drop, $\mathrm{PhD}$, Medical Sociologist ${ }^{\dagger}$

- Department of General Practice, University of Limburg

$\uparrow$ Department of Medical Sociology, University of Limburg

$\downarrow$ Department of Statistics, University of Limburg

Correspondence, request for reprints:

M. Cornel

Department of General Practice

University of Limburg

P.O. box 616

6200 MD Maastricht

The Netherlands 


\section{Abstract}

\section{Objective}

To what extent can easily available data help to identify hidden problem drinkers in a general practice population?

\section{Method}

All known problem drinkers in the practices of 16 GPs and a random sample of one in ten of the other patients (non-problem drinkers according to the GPs) were admitted to the study at their first surgery visit during a one year period. Hidden problem drinkers in the random sample were detected by a problem drinker screening questionnaire. Overall response rate was $91 \%(n=1405)$, response rate in the random sample of non-problem drinkers according to the GPs was $93 \%(n=1283)$.

\section{Main findings}

The estimated prevalence (corrected for the 1 in 10 sample) of problem drinking was $7 \%$ for the study population. We found $6 \%$ problem drinkers $(n=82)$ in the group regarded by the GPs as non-problem drinkers $(n=1283)$. Gender $(O R=6.00)$, smoking $(O R=3.56)$, life events $(O R=2.51)$ and chronic social problems (scores of 4.1 versus 2.5 for problem drinkers and nonproblem drinkers, respectively) were the strongest non-alcohol related predictors of hidden problem drinking. These variables can be used by the GP to select people at greater risk of alcohol related problems. Information about drinking habits greatly increases the degree of certainty with regard to problem drinking.

\section{Conclusions}

A preselection of patients with a greater risk of problem drinking can be made without information related directly to alcohol. Smoking men with chronic social problems and recent life events are especially at risk. These patients at least should be asked about their drinking habits.

Key words: Problem drinking, Alcoholism, General Practice, Questionnaire, Screening, Diagnosis. 


\section{Introduction}

It has been suggested that the general practitioner (GP) is in a good position to identify and treat problem drinkers (PDs). The GP is in close contact with his patients, which enables him to identify PDs in an early stage. Early detection tends to lead to better treatment outcome, perhaps even with minimal intervention'. However, the GP knows only a fraction of the problem drinkers in his patient population.

Prevalence estimates from representative Dutch population surveys show that about $10 \%$ of the population can be identified as problem drinkers ${ }^{2}$. Morbidity figures from general practice indicate that about $1 \%$ of the general practice population is diagnosed as problem drinkers ${ }^{3,4}$.

The gap between population survey estimates and GPs' estimates can partly be explained by the perhaps more restrictive definition of problem drinking used by GPs. However, it is quite likely that a substantial proportion of the problem drinkers are not recognized by their $\mathrm{GPs}^{5}$.

Laboratory markers are not valid for detection ${ }^{6,7}$. The use of questionnaires for screening purposes does not easily fit, as a first step procedure, into the working style of the GP. This paper concentrates on characteristics of hidden problem drinkers which GPs can usually observe during normal practice.

Studies of problem drinkers in general practice populations have so far been largely restricted to those recognized as problem drinkers by the $\mathrm{GP}^{8,9,10}$. Buchan $^{8}$ and Rusch ${ }^{10}$ used a control group of non-problem drinkers.

It is questionable whether data from known problem drinkers apply to problem drinkers not identified as such by the GP and hence can help in the detection proces. Only one study has used a questionnaire to detect unrecognized problem drinkers and compared these with a control group ".

The above-mentioned studies mainly concentrated on health profiles. However, more easily available data, like gender, age, life events and social problems, might also be used by the GP to identify the category of patients at risk of problem drinking. This sort of information can be the first step in the diagnostic process and can be followed by further exploration. Patients with a greater risk of problem drinking can be asked in more detail about their drinking and drinking related problems, possibly with the help of a questionnaire.

The central question of this study is to what extent easily available data contribute to the identification of patients with a higher risk of problem drinking. 
In our analysis, we distinguish four levels of information on the basis of availability to the GP. These levels include gender (level 1), life events (level 2), smoking (level 3) and reported alcohol consumption (level 4). 


\section{Methods}

\section{Background}

This study is part of an extensive study about problem drinkers in general practice. It is an observational study comparing problem drinkers identified as such by the GPs, problem drinkers not identified by the GPs and non-problem drinkers. This paper concentrates on patients who were non-problem drinkers according to the GPs.

\section{Patients}

Over a period of one year 16 general practitioners, with a total patient population of 32000 persons, were involved in the study. The study included patients aged 16 and over who attended surgery hours at least once within the specified one-year period. All known problem drinkers were admitted to the main study, as well as a random selection of one in ten of the patients who, according to the GP, were not known as problem drinkers.

\section{Measurements}

The patients selected received a questionnaire from their doctors containing questions about social background variables, drinking, smoking, drug use, physical and social wellbeing and level of alcohol consumption. The overall response rate was $91 \%$. The questionnaire comprised a screening instrument for the detection of problem drinking based on the existing screening instruments $\mathrm{CAGE}^{12}$, $\mathrm{SMAST}^{13}$ and $\mathrm{SAAST}^{14}$, and some additional screening questions ${ }^{15}$. Estimated prevalence of problem drinking was $7 \%$ according to our criterion. CAGE, SMAST and SAAST yielded prevalences of $8 \%$, $6 \%$ and $6 \%$, respectively. The Cohen's Kappas of CAGE, SMAST and SAAST for our criterion for the study population were $0.76,0.76$ and 0.82 , respectively, indicating that these instruments overlap to a large extent. Patients can be categorised into four groups (see table 1). This paper concentrates on the 1283 patients who were non-problem drinkers according to the GPs. Response rate in this group was $93 \%$.

\section{Variables}

Four levels of information were distinguished on the basis of availability to the GP. The first level contains the basic patient characteristics gender, age, marital status (being married or living together versus other), living alone versus living with others, low versus medium and high educational levels, 
unemployment or disablement pension. Age is an interval variable, the others are categorical. The second level included information obtainable from the patient record or information usually known to the GPs, such as life events ('have you recently experienced a radical or sad event that still affects you?'), chronic illnes ('do you have a chronic illness or handicap?'), use of sleeping pills and tranquillizers, as well as a scale of chronic social problems and consultation rate for the observation period. Only the last two are interval variables. Chronic social problems were measured usig the 'Long-term Difficulties Questionnaire', a 12 item list including various social problems such as those concerning work, school, financial means and personal relationships ${ }^{16}$. Problems were regarded as small, intermediate or big, scoring 1,2 , or 3 points, respectivily. The sum-score of all problems was used as a measure of social problems (Chronbach's Alpha $=0.66$ ).

The third level included smoking or non-smoking, a categorical variable. This was regarded as a separate level, since collecting information about smoking requires active questioning by the GPs. The fourth level contained information about drinking, e.g., the level of alcohol consumption (measured in standard glasses of $10 \mathrm{gr} .100 \%$ alcohol), drunkenness during the past year ( 0 versus $\geq 1$ ) and knowing people with drinking problems. Obtaining this information requires additional effort, and such questions are usually asked only after suspicion of problem drinking has been raised.

\section{Analysis}

These four levels of information were used in four models to predict the presence of problem drinking in the data set.

The relation between each of the variables and problem drinking was assessed by simple analysis, resulting in crude odds ratios with $95 \%$ confidence intervals for the categorical variables and means for the interval variables. Differences between means were tested by means of the Mann-Whitney Test. Multiple logistic regression with backward elimination of statistically nonsignificant terms from the four full models was used to select discriminating variables. Insignificant terms according to the Wald-Test were removed $(p>0.05)$, unless the variable was significant in the preceding model. Interaction terms of gender and age with all variables were selected by stepwise forward selection. Significance testing between the logistic models was performed by the likelihood ratio test.

Analysis was performed using the BMDP program. 


\section{Results}

The crude analysis shows (table 2 ) that, of the categorical variables, gender, life events, use of sleeping pills, smoking, drunkenness during the past year and knowing problem drinkers were statistically significant and rather strongly associated with problem drinking (statistically significant odds ratio $\geq 2$ ). Being unemployed or unable to work (disablement pension) was a statistically significant, but less important association. Tranquillizer use, 'not being married or not living together' and 'living alone' tended to be associated with problem drinking, but they were not significant. Low educational level was not associated with problem drinking.

Age and consultation rate (table 3 ) did not differentiate between problem drinkers and non-problem drinkers. Problem drinkers reported more social problems and drank more alcohol than non-problem drinkers.

In the first multiple logistic model (table 4 ) only gender and age were found to be significant terms. 'Being unemployed or receiving a disablement pension', which was slightly significant in the crude analysis, was no longer significant after the other variables had been taken into consideration as well. The second model (table 4), containing data that could be obtained from the patient record, was significantly better (likelihood ratio-test $p<0.01$ ). Life events and social problems were the significant variables that added information. Chronic illness, use of sleeping pills or tranquilizers and consultation did not add any information about the probability of problem drinking.

The third model (table 5), which only expanded the second model with smoking, was significantly better (likelihood ratio test $\mathrm{p}<0.01$ ).

In the fourth model (table 5) data about consumption level and drunkenness yielded a relatively high level of information, as is apparent from the difference in log likelihood with model 3 (likelihood ratio test $\mathrm{p}<0.01$ ). Age and life events were no longer significant, while knowing problem drinkers was not a significant variable either.

Of the product terms with gender and age which were added to the full model 4, only 'gender*use of sleeping pills', 'gender*consumption level' and 'age*smoking' were found to be significant (likelihood ratio test $\mathrm{p}<0.01$ ). Coefficients of these terms were $-3.688,-0.6278$ and -0.4425 . After inclusion of these 3 terms, the difference in loglikelihood for the full model 4 amounted to 7.229. This is a minor increase compared to the other steps.

Figure 1 plots the relation between the percentage of incorrectly predicted nonproblem drinkers (false positives) and the percentage of correctly predicted 
problem drinkers (true positives) at different cut-off points of the estimated posterior probability for the four models. The diagonal represents the situation in which an instrument has no predictive power. As the predictive power increases, the curve moves to the top left part of the diagram. The area under the curve is a measure of the discriminative power of the model for this patient population ${ }^{17}$. The 4 curves differ significantly. A relatively large improvement is seen when information about drinking is added. 


\section{Discussion}

Our findings support the hypothesis that background data and data from the patient record are useful for the GP in detecting problem drinkers, even if he knows nothing about their alcohol consumption. In order to find discriminating variables for hidden problem drinkers in this GP population, those problem drinkers already identified as such by the GPs were excluded.

The crude analysis shows that some 'non-alcohol variables' were clearly related to problem drinking. Among the dichotomous variables, gender had the highest odds ratio, followed by smoking, life events and the use of sleeping pills. All these variables had significant odds ratios $\geq 2$. The prevalence of chronic social problems was more than twice as high in the group of problem drinkers. This indicates that this variable did indeed differentiate between problem drinkers and non-problem drinkers.

Buchan $^{8}$ and Rush ${ }^{10}$ found that patients identified by the GP as problem drinkers had a higher consultation rate. We observed no difference in consultation rate between unrecognised problem drinkers and non-problem drinkers. Buchan's and Rush' findings for known problem drinkers as regards gender, social problems and smoking showed the same trend as ours. Nicol ${ }^{11}$, who detected unrecognised problem drinkers by means of a questionnaire, found only unemployment to be significantly associated with alcohol problems. He found no association with presenting complaints. The relation between variables directly related to drinking, such as consumption level, drunkenness and knowing problem drinkers, was clearly demonstrated, as expected.

The multiple logistic models, taking the relationships between the separate variables into consideration, showed a gain in information going from model 1 to 4 . Model 1 , with only social background variables, was supplemented with data from the patient record in model 2 and with smoking in model 3. Model 4 also contained information about drinking. A relatively important factor was information about smoking. The largest amount of extra information, however, was gained by asking about drinking behaviour. Three interaction terms, 'gender*use of sleeping pills', 'gender*consumption level' and 'age*smoking' were found to be significant, although the information gain was small. For predictive purposes, interaction terms unnecessarily complicate the model.

The results of the logistic regression allow one to estimate the risk of problem drinking in the study population for any given combination of parameters. 
Knowing only gender and age, it can be estimated with the help of model 1 that a man aged 30 has a $13 \%$ probability of being a problem drinker, while a woman of the same age has only a $2 \%$ probability. Model 3 can be used to estimate that a 30 years old man who smokes, has experienced a life event in the past year and has a score of 5 on the social problem list, has a $42 \%$ probability of being a problem drinker. This probability is high enough for a serious suspicion of problem drinking, so that the GP should ask specifically about drinking and/or drinking related problems. A woman with the same profile has an $8 \%$ probability of being a problem drinker, but if she does not smoke the probability decreases to $2 \%$. Gender is the most important general determinant (not apparently related to drinking). It should be born in mind however, that the study population included few female problem drinkers $(n=13)$. It may therefore be questioned whether conclusions about this population can be fully applied to a female population. Caution seems justified when using this model to support the detection of female problem drinkers. Although several risk factors result in the same relative increase in the probability of being a problem drinker as for males, the absolute probability of being a problem drinker remains small.

Asking about drinking adds a great deal of information. According to the model, the man from model 3 , with the additional information that he has been drunk during the past year and has 10 drinks a day, has a $72 \%$ probability of being a problem drinker.

It can be concluded that gender, life events, social problems and smoking are important indicators of hidden problem drinkers. They could be used to select patients who should at least be specifically questioned about their drinking. 


\section{Acknowledgments}

We are indebted to the late Wim van Zutphen, who was the initiator and first leader of the project.

We would like to thank HMJ Jochems, HMJ Boesten, M Dirx, P Bergmans, FLM Soomers, JMS Soomers-Turlings, PHM Passage, MCM Thomassen, A v Deelen, AJC Schlosser, PGJ v Aubel, AGTH v Hoof, HJ Berendsen, LJW Bongenaars and $\mathrm{H}$ Schiffers, general practitioners, for their invaluable help. The study was supported by a grant from the 'Netherlands Organisation for Scientific Research' (NWO). 


\section{References}

1. Wallace P, Cutler S, Haines A. Randomised controlled trial of general practitioner intervention in patients with excessive alcohol consumption. Brit Med J 1988;297:663-8.

2. Garretsen HFL, Knibbe RA. Two Dutch surveys on problem drinking. Med Sci Law 1985;4:265-8.

3. Lamberts $\mathrm{H}$, Brouwer $\mathrm{H}$, Groen ASM, Huisman $\mathrm{H}$. Het transitiemodel in de huisartspraktijk. Supplement May 1st 1987 on ICPC rubrics P15, P16. Huisarts \& Wet. 1987;30:105-13.

4. Registration Network Family Practices. Health problems and diagnoses in family practice, University of Limburg, The Netherlands, Maastricht, 1992.

5. Cornel M, Van Zutphen WM. Recognition of problem drinkers and the role of the general practitioner. Can Fam Phys 1989;35:1167-9.

6. Beresford TP, Blow FC, Hill E, Singer K, Lucey MR. Comparison of CAGE questionnaire and computer-assisted laboratory profiles in screening for covert alcoholism. Lancet 1990;336:482-5.

7. Wallace $\mathrm{P}$, Haines $\mathrm{A}$. Use of a questionnaire in general practice to increase the recognition of patients with excessive alcohol consumption. Brit Med J 1985;290 :1949-53.

8. Buchan JC, Bucki EG, Deacon GLS, Irvine R, Ryan MP. Problem drinkers and their problems. J R Coll Gen Pract 1981;31:151-3.

9. Hore BD, Wilkins RH. A general-practice study of the commonest presenting symptoms of alcoholism. J R Coll Gen Pract 1976;26:140-2.

10. Rush B, Brennan M. Is the health profile of problem drinkers different from that of other patients? J Fam Pract 1990;31:42-6.

11. Nicol EF, Ford MJ. Use of the Michigan Alcoholism Screening Test in general practice. J R Coll Gen Pract 1986;36:409-10.

12. Mayfield D, McLeod G, Hall P. The CAGE questionnaire: Validation of a new alcoholism screening instrument. Am J Psychiat 1974;131:1121-3.

13. Selzer ML, Vinokur A, Van Rooijen L. A self-administered Short Michigan Alcoholism Screening Test (SMAST). J Stud Alcohol 1975;36:117-26.

14. Davis LJ, Hurt RD, Morse RM, O'Brien PC. Discriminant analysis of the SelfAdministered Alcoholism Screening Test. Alcohol Clin Exp Res 1987;11:269-73. 
15. Comel M, Knibbe RA, Van Zutphen WM, Drop MJ. Problem drinking in a general practice population: the construction of an interval scale for severity of problem drinking. J Stud Alcohol 1994;55:466-70.

16. Hendriks AAJ, Ormel J, Van de Willige G. Langdurige moeilijkheden gemeten volgens zelfbeoordelingsvragenlijst en semi-gestructureerd interview. Een theoretische en empirische vergelijking. Gedrag en Gezondheid 1990;18:273-83.

17. Hanley JA, McNeill BJ. The meaning and use of the area under a receiver operating characteristic (ROC) curve. Radiology 1982;143:29-36. 
Table 1: Distribution of problem drinkers according to the GPs and screening test.

\begin{tabular}{l|c|c|l} 
& SCREENING PD $+^{*}$ & SCREENING PD - & \\
\hline${\text { GP PD }+^{\dagger}}^{\dagger}$ & 86 & 36 & 122 \\
\hline GP PD ${ }^{+}$ & 82 & 1201 & 1283 \\
\hline & 168 & 1237 & 1405
\end{tabular}

- Screening PD +/-: results of problem drinking screening test.

+ GP PD +/-: problem drinkers according to GPs / 1 in 10 sample of non-problem drinkers according to the GPs. 
Table 2: Numbers and percentages of problem drinkers $(n=82)$ and nonproblem drinkers $(n=1201)$ in relation to categorical variables, unadjusted odds ratios (OR) with $95 \%$ confidence intervals (CI).

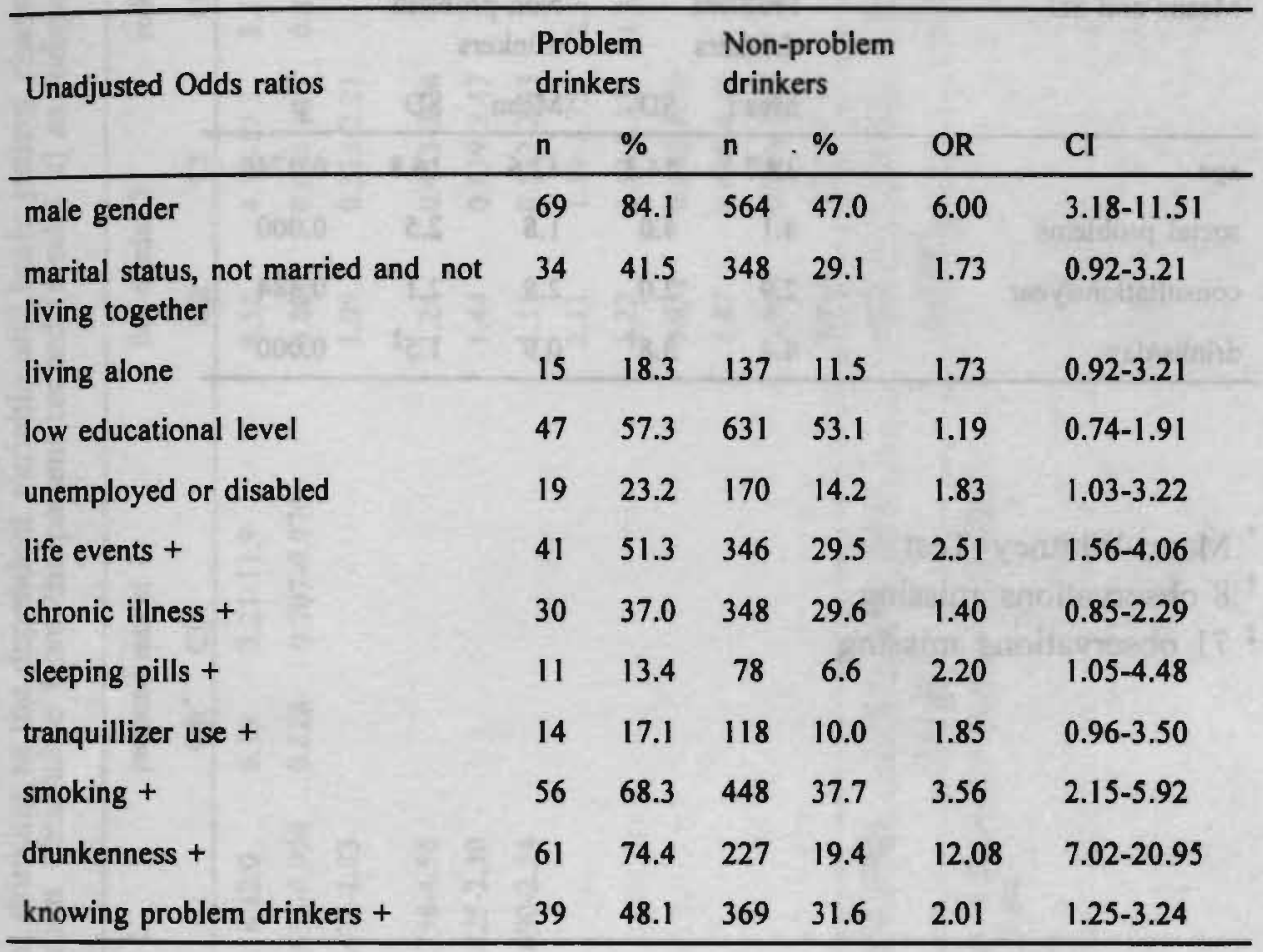


Table 3: Mean values and standard errors of problem drinkers $(n=82)$ and non-problem drinkers $(n=1201)$ in relation to interval variables.

\begin{tabular}{llllll}
\hline Means and SD & \multicolumn{3}{l}{$\begin{array}{l}\text { Problem } \\
\text { drinkers }\end{array}$} & \multicolumn{4}{l}{$\begin{array}{l}\text { Non-problem } \\
\text { drinkers }\end{array}$} \\
& Mean & SD & Mean & SD & p $^{*}$ \\
\hline age & 38.7 & 14.3 & 42.6 & 16.8 & 0.0749 \\
social problems & 4.1 & 4.0 & 1.8 & 2.5 & 0.000 \\
consultations/year & 2.9 & 2.0 & 2.8 & 2.1 & 0.384 \\
drinks/day & 4.4 & $3.8^{\dagger}$ & 0.9 & $1.5^{\ddagger}$ & 0.000 \\
\hline
\end{tabular}

Mann-Whitney Test

† 8 observations missing

71 observations missing 
Table 4: Logistic regression with problem drinking as the dependent variable and basic patient characteristics (model $1)$, in combination with information obtainable from the patient record (model 2) as independent variables.

\begin{tabular}{|c|c|c|c|c|c|c|c|c|}
\hline \multirow{2}{*}{ MODELS 1 and 2} & \multicolumn{2}{|c|}{ full model 1} & \multicolumn{2}{|c|}{ reduced model 1} & \multicolumn{2}{|c|}{ full model 2} & \multicolumn{2}{|c|}{ reduced model 2} \\
\hline & $\mathrm{OR}^{\circ}$ & $\mathrm{CI}$ & $\mathrm{OR}^{*}$ & $\mathrm{CI}$ & $\mathrm{OR}^{*}$ & $\mathrm{CI}$ & $\mathrm{OR}^{*}$ & $\mathrm{CI}$ \\
\hline gender ( $1=$ man, $0=$ woman) & 6.17 & $3.18-12.0$ & 6.19 & $3.21-11.9$ & 8.52 & $4.19-17.3$ & 8.55 & $4.26-17.1$ \\
\hline age (/10 years) & 0.774 & $0.635-0.994$ & 0.828 & $0.707-0.970$ & 0.806 & $0.644-1.01$ & 0.825 & $0.692-0.948$ \\
\hline $\begin{array}{l}\text { marital status (not married/not living } \\
\text { together=1, maried/living together }=0 \text { ) }\end{array}$ & 0.930 & $0.473-1.83$ & & & 1.09 & $0.533-2.21$ & & \\
\hline living alone (alone $=1$, with others $=0$ ) & 1.86 & $0.758-4.56$ & & & 1.24 & $0.473-3.26$ & & \\
\hline education (low $=1$, medium $/ \mathrm{high}=0$ ) & 1.38 & $0.825-2.30$ & & & 1.44 & $0.839-2.47$ & & \\
\hline work (unemployed/disabled $=1$, other $=0$ ) & 1.32 & $0.690-2.54$ & & whares & 1.11 & $0.532-2.33$ & & \\
\hline life events $(1=$ yes, $0=$ no $)$ & Hrs & 027 & & & 2.11 & $1.19-3.75$ & 2.15 & $1.24-3.73$ \\
\hline social problems (score) & y's & devetsop & & & 1.22 & $1.12-1.33$ & 1.23 & $1.13-1.33$ \\
\hline chronic illness ( $1=$ yes, $0=$ no) & 101 & ar) $13=5410$ & & & 0.931 & $0.491-1.76$ & & \\
\hline sleeping pills ( $1=y e s, 0=$ no) & & & & & 1.47 & $0.499-4.31$ & & \\
\hline tranquillizer use $(1=y e s, 0=n o)$ & 300 & 0802 & & & 0.965 & $0.379-2.46$ & & \\
\hline consultation/year & Q63 & & 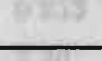 & $\ln 2 x$ & 0.946 & $0.821-1.09$ & & \\
\hline constantt & \multicolumn{2}{|c|}{$-3.18+/-1.02(2 \mathrm{SD})$} & \multicolumn{2}{|c|}{$-3.18+/-0.84(2 \mathrm{SD})$} & \multicolumn{2}{|c|}{$-4.22+/-1.20(2 \mathrm{SD})$} & \multicolumn{2}{|c|}{$-4.22+1-0.98(2 \mathrm{SD})$} \\
\hline log likelihood & \multicolumn{2}{|c|}{-242.249} & \multicolumn{2}{|c|}{-244.771} & \multicolumn{2}{|c|}{-220.942} & \multicolumn{2}{|c|}{-222.865} \\
\hline
\end{tabular}

'OR's have been computed as the natural antilogarithm of the logistic regression coefficient

+ For the constant the logistic regression coefficient is given 
Table 5: Logistic regression with problem drinking as the dependent variable and basic patient characteristics, information obtainable from the patient record and smoking (model 3 ), in combination with information about drinking (model 4) as independent variables.

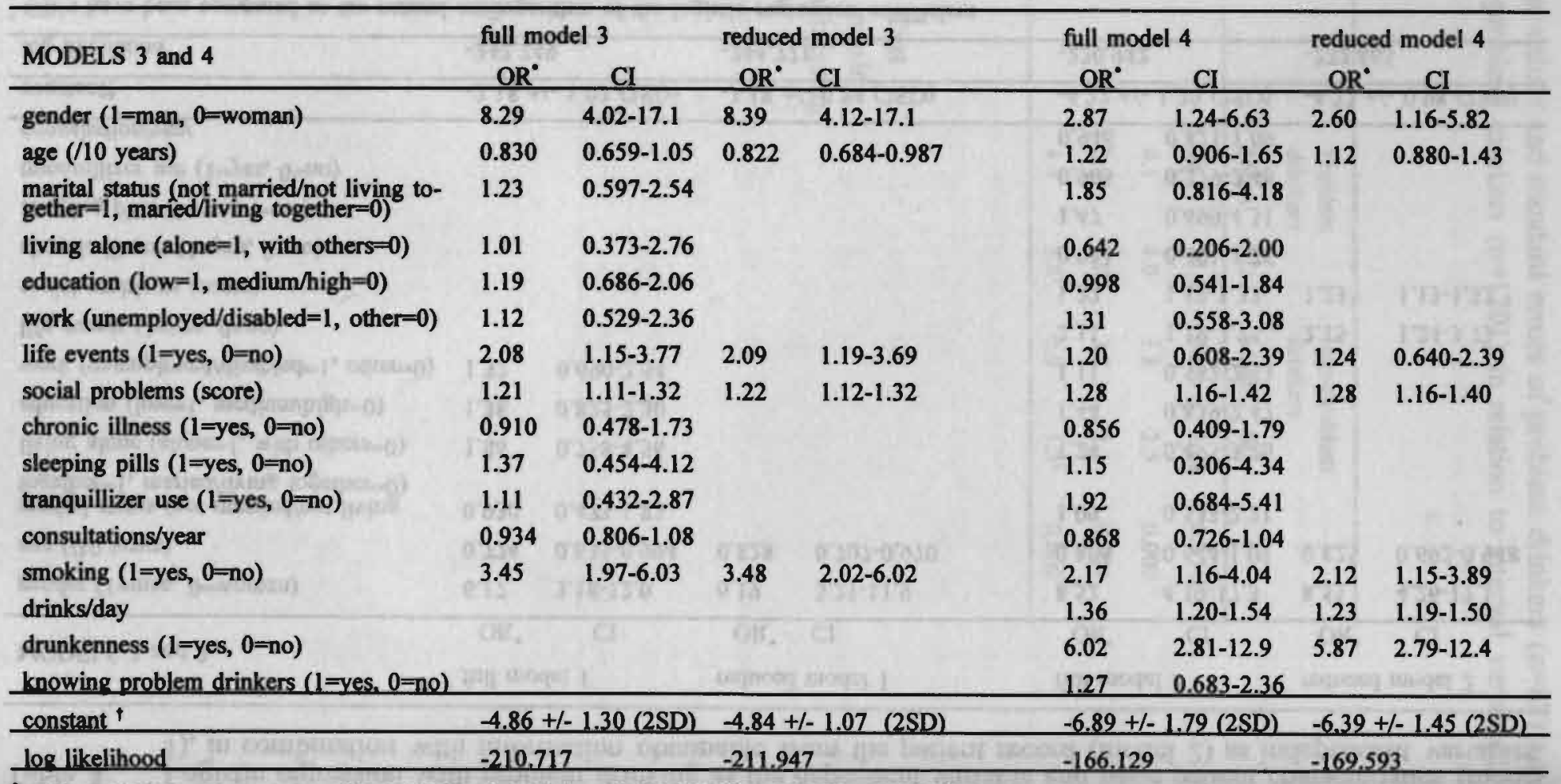

OR's have been computed as the natural antilggarithm of the logistie regression coefficient
; 
Figure 1: Prediction of problem drinking in the study population with the help of the 4 logistic models. The percentage of incorrectly predicted non-problem drinkers (false positives) is plotted against the percentage of correctly predicted problem drinkers (true positives) at different cut-off points of the estimated posterior probability for the four models.

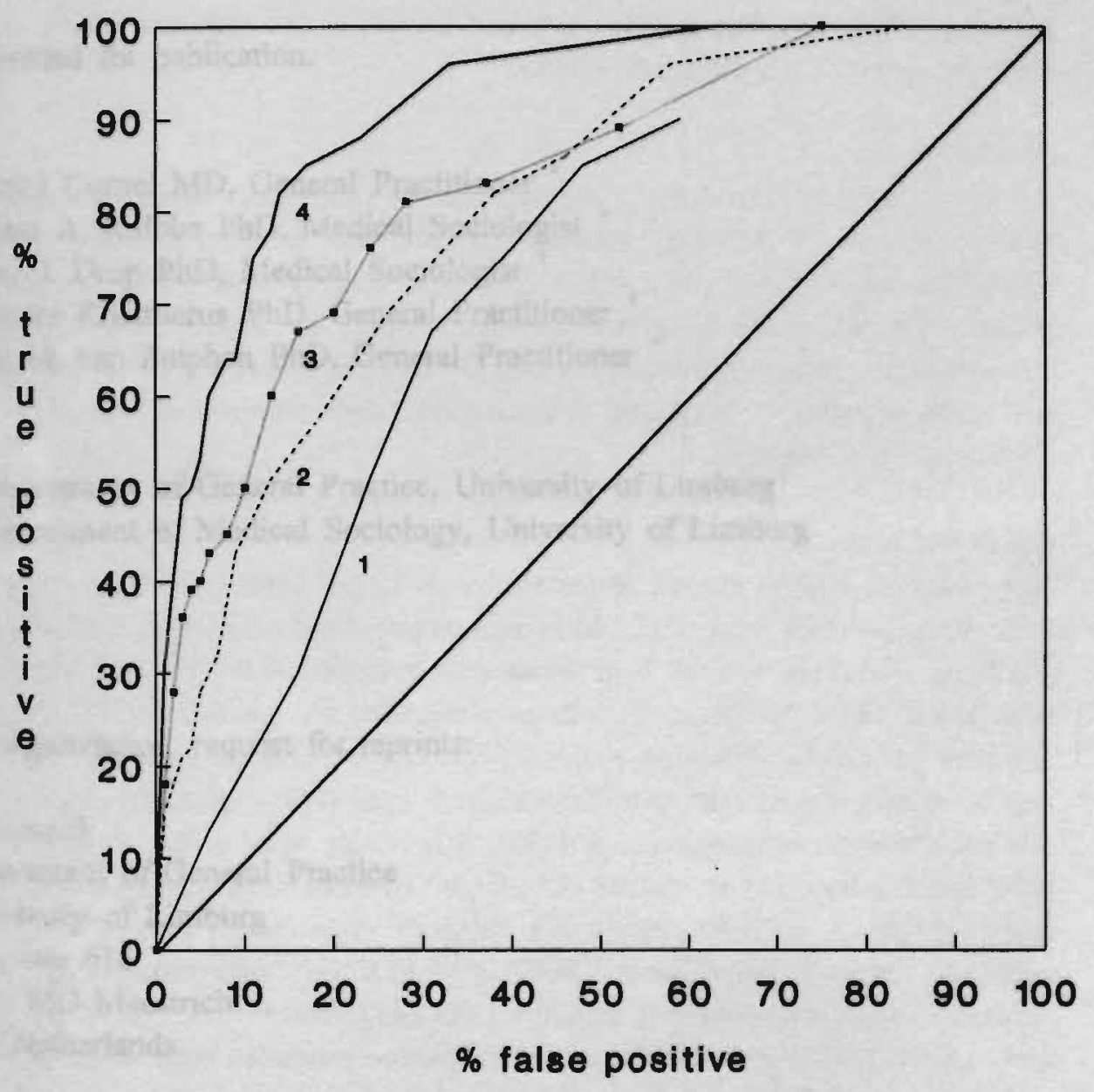

- Model 1

Model 2

- Model 3

Model 4 


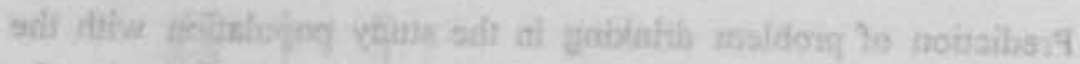

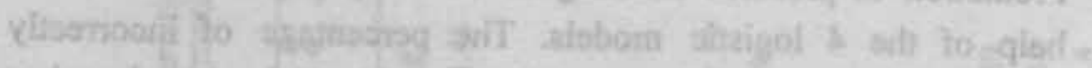

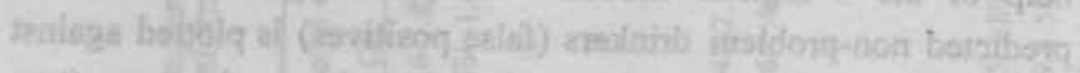

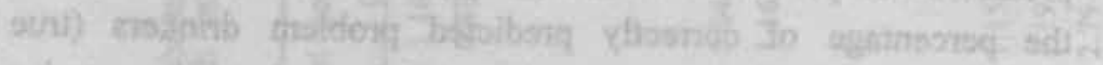

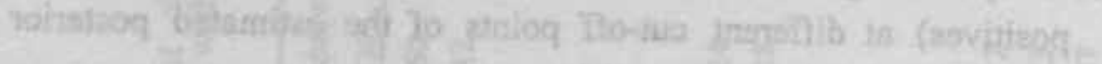
dif

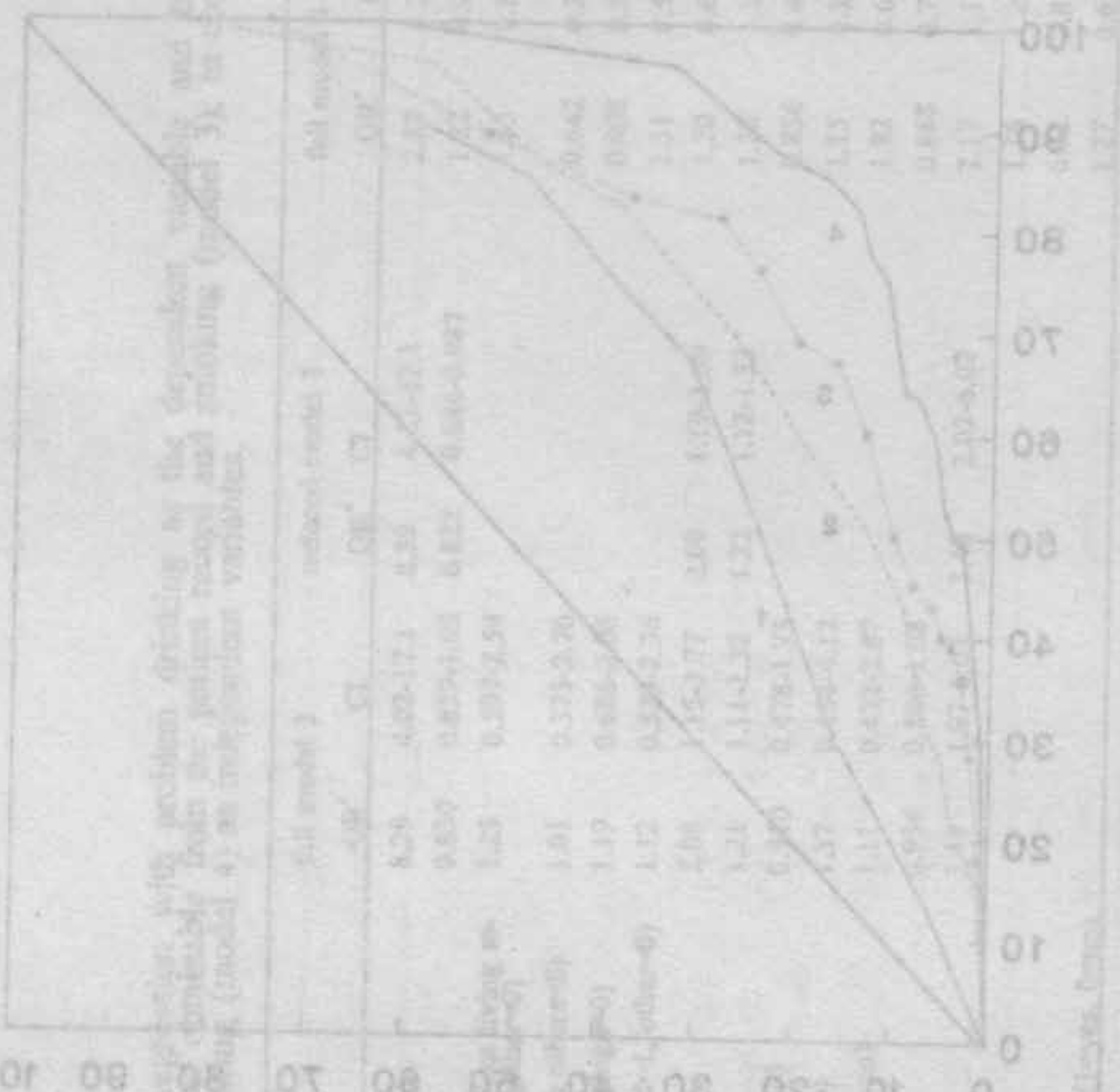

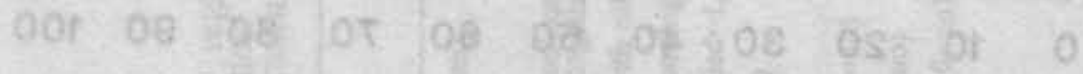
sviliauch gais to

Q lubouf

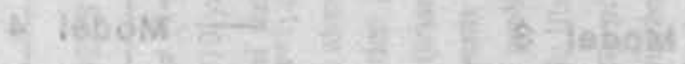

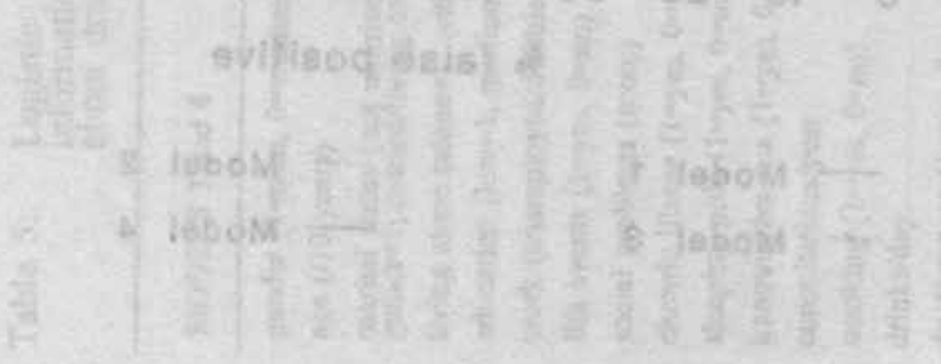




\section{Chapter 6}

\section{Reasons for encounter and diagnoses:}

do they predict hidden problem drinking in general practice?

Submitted for publication.

Michiel Cornel MD, General Practitioner *

Ronald A. Knibbe PhD, Medical Sociologist ${ }^{\dagger}$

Maria J. Drop PhD, Medical Sociologist ${ }^{\dagger}$

J. André Knottnerus $\mathrm{PhD}$, General Practitioner

Wim M. van Zutphen PhD, General Practitioner

- Department of General Practice, University of Limburg

† Department of Medical Sociology, University of Limburg

Correspondence, request for reprints:

\section{Cornel}

Department of General Practice

University of Limburg

P.O. box 616

6200 MD Maastricht

The Netherlands 


\section{Summary}

\section{Objective}

To find predictors for hidden problem drinkers in a general practice population. The Dutch College of General Practitioners has developed a 'Standard' for the detection of problem drinkers (Dutch Alcohol Standard) based on the literature. Reasons for encounter (RFEs) and evaluations (Es) play a major role in this 'Standard'. We investigated to what extent this 'Standard', which is largely based on data from known problem drinkers, usually in inpatient settings, applies to problem drinkers not known to the GP, and hence could help the latter in the detection proces.

\section{Method}

All known problem drinkers in the practices of 16 GPs, as well as a one in ten random sample of the other patients (non-problem drinkers according to the GPs) were admitted to the study at their first surgery visit during a one year period. Hidden problem drinkers were detected by means of a screening questionnaire. Over a period of 1 year, the GPs registered all RFEs and Es of the study population. RFE and E sumscores were constructed, based on the Dutch Alcohol Standard.

\section{Main findings}

1537 patients were admitted to the study, of whom 1500 were followed for 1 year. Response rate was $91 \%$. The estimated population prevalence of problem drinking, corrected for the 1 in 10 sample fraction, was $7 \%$. We found $6 \%$ problem drinkers $(n=78)$ in the category regarded by the GPs as non-problem drinkers $(n=1254)$. Although mean RFE and $E$ sumscores were significantly higher among the known problem drinkers and hidden problem drinkers in comparison with non-problem drinkers, differences were small. Applying the RFE and E sumscores at various cut-off points, there were significant ORs for known problem drinkers versus the category regarded by the GPs as nonproblem drinkers (significant ORs 1.69-5.62). For unrecognized problem drinkers versus non-problem drinkers ORs (significant ORs 1.87-2.66) were only significant at low cut-off points. Predictive power in both situations was low because of the relatively large overlap in the sumscores. 


\section{Conclusions}

Generally advocated diagnostic predictors for problem drinking have poor predictive value in general practice. This is probably due to the fact that these predictors are based upon known problem drinkers, mainly from inpatient populations

Key words: $\quad$ Problem drinking, Alcoholism, General Practice, Questionnaire, Screening, Diagnosis. 


\section{Introduction}

The Dutch College of General Practitioners has developed a 'Standard' for the detection of problem drinkers (PDs) ${ }^{1,2}$. Representative Dutch population surveys ${ }^{3}$ have estimated a prevalence of $10 \%$. Morbidity figures from general practice indicate that about $1 \%$ of the general practice population is diagnosed as problem drinkers ${ }^{4,5}$.

The gap between the population survey estimates and the general practitioners' (GPs') estimates can be partly explained by a possibly more restrictive definition of problem drinking used by general practitioners. However, it is quite likely that a substantial proportion of the problem drinkers is not recognized by their $\mathrm{GPs}^{6}$. This contrasts with the fact that the GP is in close contact with his patients, which should enable him to identify PDs at an early stage. Early detection is, moreover, expected to lead to better treatment outcome, perhaps even with minimal intervention?

To facilitate detection of problem drinkers, characteristics of patients consulting the GP could be used to preselect those for whom specific evaluation is justified. Possible predictors could be background data or health status, as represented by reasons for encounter and diagnoses. We have already reported that background data like gender, smoking, life events and chronic social problems are the strongest not evidently alcohol related predictors of hidden problem drinking (Comel M, Knibbe RA, Knottnerus JA, Volovics A, Drop MJ. Predictors for hidden problem drinkers in general practice, submitted for publication). The Dutch Alcohol Standard mentions the abovementioned background variables, but also contains a list of reasons for encounter (RFEs) and diagnoses (Es). These predictors were based on a literature review.

The RFEs and Es in the 'Dutch Alcohol Standard' were mainly derived from inpatient experience with known problem drinkers. It may be questioned whether these RFEs and Es are also characteristic of problem drinkers not known as such to the GP and hence could help the latter in the detection proces. This study reports to what extent the RFEs and Es listed in the Dutch Alcohol Standard discriminate between known problem drinkers and the rest of the GP population on the one hand and between unrecognized problem drinkers and a control group of non-problem drinkers on the other hand. The comparison between known problem drinkers and the rest of the population allows one to compare the extent to which our study replicates findings from the mainly inpatient population studies with known problem drinkers on which the 'Standard' was based. The comparison of unrecognized problem drinkers 
with a control group of non-problem drinkers enables one to specify the value of these studies for the detection of unrecognized problem drinkers in a general practice population. 


\section{Methods}

\section{Design}

This study is part of an extensive observational study of problem drinkers in general practice, which compares problem drinkers known as such to the GPs, problem drinkers not known as such to the GPs and non-problem drinkers. Patients received a questionnaire screening for problem drinking and measurering background variables. GPs registered the consultations of these patients.

\section{Patients}

Over a period of one year 16 general practitioners, with a total patient population of 32000 persons, were involved in the study. The study included patients aged 16 and over who attended surgery hours at least once within the specified one-year period. All known problem drinkers $(n=153)$ were admitted to the study, as well as a random selection of one in ten of the consulting patients who, according to the GP's judgment, were not problem drinkers $(n=1384)$, resulting in a total of 1537 patients. The patients selected received a questionnaire from their doctor containing questions about social background variables, drinking, smoking, use of tranquillizers and sleeping pills, physical and social wellbeing and level of alcohol consumption. The response rate was $91 \%$.

During the one year observation period 30 persons moved or changed their GP, while 7 persons died. These 37 patients were excluded from the analysis. Eventually, the study included 147 known problem drinkers and 1353 patients (from the $10 \%$ sample) who were not problem drinkers according to their GP. Of the 1353 patients, $93 \%$ responded to the screening questionnaire $(n=1254)$. This screening resulted in 78 hidden problem drinkers and 1176 non-problem drinkers.

This paper concentrates on the 147 patients who were regarded as problem drinkers by their GP, on the 78 unrecognized/hidden problem drinkers and on the 1176 non-problem drinkers.

\section{Questionnaire}

The questionnaire comprised a screening instrument for the detection of problem drinking based on the existing screening instruments CAGE SMAST $^{9}$ and SAAST ${ }^{10}$, and some additional screening questions ${ }^{11}$. The estimated prevalence of problem drinking in the population visiting the GP at 
least once a year was $7 \%$ according to our criterion. CAGE, SMAST and SAAST showed prevalences of $8 \%, 6 \%$ and $6 \%$ respectively. The Cohen's Kappas of CAGE, SMAST and SAAST using our criterion for the study population were $0.76,0.76$ and 0.82 respectively, indicating that these instruments overlap to a large extent.

\section{Consultation data}

When the patients included came for consultation, Reasons for Encounter (RFEs) and Evaluations (Es) of these patients were recorded by the GPs on separate forms. These RFEs and Es were coded centrally according to the ICPC classification ${ }^{12}$. Indicators of problem drinking from the Dutch Alcohol Standard were coded according to the ICPC. The codes and short descriptions are presented in the appendix. Since the 'Standard' makes no distinction between RFE and $\mathrm{E}$, the indicators named were studied at both the RFE level and the E level. RFE as well as E sumscores were constructed for each patient. These sumscores represent the number of different ICPC codes of the Dutch Alcohol Standard that were assigned at least once to a patient in the one year period, coded as RFE (RFE score) and as E (E score). This means that a patient who consulted his GP 5 times for hypertension gets a sumscore of one. Five times for hypertension and once for headache yields a sumscore of 2.

\section{Analysis}

For each code of the Dutch Alcoholism Standard, we calculated the percentage of persons to whom this code was assigned at least once, as RFE and $\mathrm{E}$. This was done for the known problem drinkers $(n=147)$, the unrecognized/hidden problem drinkers $(n=78)$ and the non-problem drinkers $(n=1176)$. Means and SDs of RFE and E sumscores on the standard, as well as the numbers of consultations in the observation period, were computed for the abovementioned three groups of patients. Differences in means were tested using the Mann-Whitney test.

Discriminating abilities of the RFE and E sumscores were determined in two situations. The first involved discriminating between known problem drinkers $(n=147)$ and those regarded as non-problem drinkers by the GPs $(n=1353$, including non-response on screening). We used the larger sample, including non-respondents, because it consisted of those regarded by the GP as problem drinkers and non-problem drinkers. This resulted in a maximum of statistical power. The second situation involved the discriminating abilities in the 
category of those regarded as non-problem drinkers by their GPs, between unrecognized problem drinkers $(n=78)$ and those shown by screening to be non-problem drinkers $(n=1176)$. The percentage of problem drinkers was calculated for scoring categories $0-5$. Sensitivity, specificity, positive predictive value, negative predictive value and odds ratios (OR) of the sumscore were computed for various cut-off points of the RFE and E sumscores. A Receiver Operating Characteristic (ROC) curve was plotted. The statistical significance of ORs was determined using the Fisher-exact test. 


\section{Results}

For each of the ICPC codes, table 1 presents the percentage of patients in the 3 categories with that code as RFE and E (known problem drinkers, unrecognized/hidden problem drinkers and non-problem drinkers). Significant differences (one tailed Fisher-exact test $\mathrm{p} \leq 0.05$ ) between known problem drinkers and those who were non-problem drinkers according to the GPs were found for RFE and E codes with regard to social problems, digestive problems, gout and fractures. Psychological problems, accidents, perspiration problems and red eye were only significant at the RFE level, gastritis at the $E$ level. Differences in RFE and E between hidden problem drinkers and those regarded as non-problem drinkers by GPs and screening were significant for irregular heartbeat and psychological problems. Sexual problems were significant at the RFE level, social problems at the E level.

Table 2 presents the means and SDs of RFE sumscores, E sumscores and numbers of consultations for the three categories. Known problem drinkers had the highest sumscores, followed by the hidden problem drinkers. Differences in RFE and $E$ sumscores between known problem drinkers and hidden problem drinkers on the one hand, and non-problem drinkers on the other hand, were significant. The differences cannot be attributed to differences in consultation frequency or total number of RFEs or Es of the three categories. Differences between known problem drinkers and hidden problem drinkers were not significant.

In the total population of 1500 patients, the percentage of known problem drinkers in the score groups $0,1,2,3,4,5$ and higher amounted to $6.8 \%$, $11.1 \%, 18.7 \%, 18.9 \%, 18.8 \%$ and $37.5 \%$ respectively for the RFE scores and to $6.7 \%, 11.6 \%, 11.1 \%, 22.7 \%, 9.1 \%$ and $28.6 \%$ respectively for the $\mathrm{E}$ scores. In the category of those regarded by the GPs as non-problem drinkers, the percentage of hidden problem drinkers in the score groups $0,1,2,3,4,5$ and higher amounted to $4.7 \%, 7.2 \%, 12.4 \%, 10.0 \%, 8.3 \%$ and $0 \%$ respectively for the RFE scores and to $4.0 \%, 7.9 \%, 6.9 \%, 13.6 \%, 20 \%$ and $0 \%$ respectively for the $\mathrm{E}$ sumscores.

Table $3 a$ presents sensitivity, specificity, positive predictive value, negative predictive value, odds ratio and Fisher-Exact p-values at different cut-off points for RFEs and Es in known problem drinkers versus non-problem drinkers. The Fisher-Exact test was significant for RFE at cut-off points $0-4$, for $\mathrm{E}$ at cut-off points $0-3$. Table $3 \mathrm{~b}$ presents these same data for hidden problem drinkers versus those regarded by the GPs as non-problem drinkers. 
The Fisher-Exact test was significant for RFE at cut-off points 0-1, for $\mathrm{E}$ at cut-off point $0-2$. The ORs tended to be lower for the hidden problem drinkers than for the known problem drinkers. At different cut-off points of the RFE and $\mathrm{E}$ sumscores, the sensitivity and specificity of the criterion were plotted in a Receiver Operating Characteristic (ROC) curve (figure 1). The figure shows clearly that the RFE and E scores only marginally improve the prediction of problem drinking. 


\section{Discussion}

The GP has no reliable diagnostic instruments for the detection of problem drinkers. Laboratory markers are not valid for detection ${ }^{13}$. The use of questionnaires as a first diagnostic step during surgery hours does not fit in well with the working style of the GP. They can be useful only after a first suspicion has already been raised.

The Dutch Alcohol Standard aims to help the general practitioner in the detection of problem drinkers. The list of RFEs and Es included in this Standard was based on a literature review, but there are some important limitations to this review.

Firstly, some references were not original studies on this topic; they were more or less extensive review articles ${ }^{14,15,16,17,18,19}$ or reports about other aspects of problem drinking, yielding, as a by-product, RFEs and Es not directly based on patient data ${ }^{20,21,22}$.

Secondly, some studies described populations outside general practice, such as a survey study ${ }^{23}$, studies of referred ${ }^{24}$ or inpatient ${ }^{25}$ populations and a study of an inpatient population with a control group of general practice patients $^{26}$. Generalizing these data to the general practice population is problematic, because selection bias may have influenced sensitivity and specificity figures ${ }^{27}$ : only heavy drinkers are found in inpatient settings.

In addition, the cited studies of problem drinkers in general practice populations have been largely restricted to problem drinkers known as such to the $\mathrm{GP}^{28,29}$. Van Rens ${ }^{29}$ did not use a control group. Only Wilkens ${ }^{30}$, who constructed an 'Alcohol at risk register', carried out a study which also included problem drinkers not known as such to the GP. He found a higher prevalence of problem drinking among the group of patients with one or more risk factors. Prevalence varied from $100 \%$ for patients with tremors to $50 \%$ for patients with gastritis and $25 \%$ for patients with marital problems in a preselected population with one or more risk factors.

At the time when the Dutch Alcohol Standard was being developed, nearly all available information was included. There were two other studies which were not mentioned in the standard. Rush ${ }^{31}$ studied known problem drinkers, and he came to almost the same conclusions as Buchan et $\mathrm{al}^{28}$. Problem drinkers had a high doctor contact rate and a higer prevalence of mental health dysfunction, gastrointestinal problems, traumatic injury, and social or family problems. Only one study, by $\mathrm{Nicol}^{32}$, recruted problem drinkers in general practice by means of a questionnaire. Although problem drinkers were found 
to have a higher consultation rate, no differences were observed between problem drinkers and non-problem drinkers as regards psychoneurotic profile or presenting complaints. This negative finding could perhaps be explained by the small population in the study (18 problern drinkers not identified as such by their GP).

It is clear from our study that, at the level of RFE or E, most of the ICPC codes in the Standard show no significant differences between problem drinkers and non-problem drinkers. There tend to be more significant differences between known problem drinkers and the rest of the population than between hidden problem drinkers and non-problem drinkers. This confirms that the information of RFEs and Es is based on known problem drinkers. Only psychological, social and sexual problems and irregular heartbeat seem to have predictive value for the detection of unrecognized/hidden problem drinkers. However, considering the size of the study, the lack of significant differences between problem drinkers and non-problem drinkers means that the usefulness for the GP in detecting problem drinkers is at best very limited.

At the more condensed level of the RFE and E sumscores (table 2), differences between known problem drinkers and hidden problem drinkers on the one hand and non-problem drinkers on the other were significant. Differences between known and unrecognized/hidden problem drinkers were not significant, but there was a tendency for the known problem drinkers to score higher. Differences were small compared to the standard errors, so that prediction at the patient level is probably inaccurate. This is demonstrated by the data in tables $3 \mathrm{a}$ and $3 \mathrm{~b}$ and the ROC curves.

Problem drinking has a wide range of causes and effects. In extreme forms of alcoholism, a palpable liver, pancreatitis or peripheral neuropathy are good predictors for problern drinking, but they are no longer relevant at that stage, since the problem drinker will by then already be known as such to his/her physician. As regards early recognition of problem drinking in particular, it may be questioned whether the wide range of known causes and effects relating to problem drinking are of value for detection. Because of the high prevalence of problem drinking in the GP population, a better strategy for the GP would be to ask patients about their drinking. As reported earlier, background data like gender, smoking, life events and chronic social problems have some predictive value and can be used to select a group which is at greater risk. 


\section{References}

1. Grol R. National standard setting for quality of care in general practice: attitudes of general practitioners and response to a set of standards. J Roy Coll Gen Pract 1990;40:361-4.

2. Van Zutphen WM, Van Olst EJ, Cornel M, Willink AE, Hoeksema HL. NHGstandaard 'Problematisch alcoholgebruik'. Huisarts \& Wet. 1990;33:280-5.

3. Garretsen HFL, Knibbe RA. Two Dutch surveys on problem drinking. Med Sci Law 1985;4:265-8.

4. Lamberts $\mathrm{H}$, Brouwer $\mathrm{H}$, Groen ASM, Huisman H. Het transitiemodel in de huisartspraktijk. Supplement May 1st 1987 on ICPC rubrics P15, P16. Huisarts \& Wet. 1987;30:105-13.

5. Registration Network Family Practices. Health problems and diagnoses in family practice, University of Limburg, The Netherlands, Maastricht, 1992.

6. Cornel M, Van Zutphen WM. Recognition of problem drinkers and the role of the general practitioner. Can Fam Phys 1989;35:1167-9.

7. Wallace $P$, Cutler S, Haines A. Randomised controlled trial of general practitioner intervention in patients with excessive alcohol consumption. Brit Med J $1988 ; 297: 663-8$.

8. Mayfield $D$, McLeod G, Hall P. The CAGE questionnaire: Validation of a new alcoholism screening instrument. Am J Psychiat 1974;131:1121-3.

9. Selzer ML, Vinokur A, Van Rooijen L. A self-administered Short Michigan Alcoholism Screening Test (SMAST). J Stud Alcohol 1975;36:117-26.

10. Davis LJ, Hurt RD, Morse RM, O'Brien PC. Discriminant analysis of the SelfAdministered Alcoholism Screening Test, Alcohol Clin Exp Res 1987;11:269-73.

11. Cornel M, Knibbe RA, Van Zutphen WM, Drop MJ. Problem drinking in a general practice population: the construction of an interval scale for severity of problem drinking. J Stud Alcohol. In press.

12. Lamberts H, Wood M. International Classification of Primary Care. New York, Oxford University Press, 1987.

13. Beresford TP, Blow FC, Hill E, Singer K, Lucey MR. Comparison of CAGE questionnaire and computer-assisted laboratory profiles in screening for covert alcoholism. Lancet 1990;336:482-5.

14. Anonymous. Alcohol a Balanced View. Report from General Practice 24. Exeter Publication Office, London, 1986. 
15. Van Limbeek J. Alcoholproblemen en de Arts. Ned Tijds Gen 1989;133:281-4.

16. Skinner HA, Holt S, Israel Y. Early identification of alcohol abuse: 1. Critical issues and psychosocial indicators for a composite index. Can Med Assoc J 1981;124:1141-52.

17. Holt S, Skinner HA, Israel Y. Early identification of alcohol abuse: 2: Clinical and laboratory indicators. Can Med Assoc J 1981;124:1279-94.

18. Anoniem. Herkennen en bespreekbaar maken van alcoholproblemen door de huisarts. CAD, Assen, 1981.

19. National Counsel on Alcoholism. Criteria for the diagnosis of alcoholism. Ann Intern Med 1972;77:249-58.

20. Van Limbeek J, Walburg JA. De vroege signalering van alcoholproblematiek. [dissertation]. Lisse: Swets \& Zeitlinger, 1987.

21. Van Dalen WE, Van der Eijk R. Het signaleren en bespreekbaar maken van alcoholproblemen in de huisartsprakijk. Tijdschr Alc Drugs 1982;8:24-7.

22. Van Limbeek J, Walburg JA, Groothedde W, Geerlings PJ, Jonghe de FER. Een model voor de vroegtijdige diagnostiek van alcohol verslaving. Huisarts \& Wet 1986;29(suppl H\&P 10):23-7.

23. Garretsen HFL, Knibbe RA. Alcohol prevalentie onderzoek Rotterdam/Limburg, landelijk eindrapport. Rijswijk, Ministerie van WVC, 1983.

24. Hore BD, Wilkins RH. A general-practice study of the commonest presenting symptoms of alcoholism. J Roy Coll Gen Pract 1976;26:140-2.

25. Ashley MJ, Olin JS, Harding le Riche B, Kornaczewski A, Schmidt W, Corey PN, Rankin JG. The physical disease characteristics of inpatient alcoholics. J Stud Alcohol 1981;42:1-14.

26. Skinner HA, Holt S, Sheu WJ, Israel Y. Clinical versus laboratory detection of alcoholabuse: the alcohol clinical index. Brit Med J 1986;292:1703-8.

27. Knottnerus JA. Medical decision making by general practitioners and specialists. Farn Pract 1991;8:305-307.

28. Buchan JC, Bucki EG, Deacon GLS, Irvine R, Ryan MP. Problem drinkers and their problems. J Roy Coll Gen Pract 1981;31:151-3.

29. Van Rens HAJ, Cornel M, Van Zutphen WM. Herkenning van problematisch alcoholgebruik in de huisartspraktijk. Huisarts \& Wet. 1989;133:48-50.

30. Wilkens RH. Waarom moeite doen potentiele alcoholisten op te sporen? T Alc Drugs 1976;2:134-6. 
31. Rush B, Brennan M. Is the health profile of problem drinkers different from that of other patients? J Fam Pract 1990;31:42-6.

32. Nicol EF, Ford MJ. Use of the Michigan alcoholissm screening test in general practice. J Roy Coll Gen Pract 1986;36:409-10. 


\section{Acknowledgments}

We would like to thank HMJ Jochems, HMJ Boesten, M Dirx, P Bergmans, FLM Soomers, JMS Soomers-Turlings, PHM Passage, MCM Thomassen, A v Deelen, AJC Schlosser, PGJ v Aubel, AGTH v Hoof, HJ Berendsen, LJW Bongenaars and $\mathrm{H}$ Schiffers, general practitioners, for their invaluable help. The study was supported by a grant from the 'Netherlands Organisation for Scientific Research' (NWO). 
Table 1: Percentage of persons in the categories of known problem drinkers (group $A, n=147$ ), problem drinkers not known as such by the GPs (Group B, $n=78$ ) and non-problem drinkers (Group C, $n=1176$ ) with at least one ICPC code as Reason for Encounter (RFE) and Evaluation (E) according to the Dutch Alcohol Standard. The column percentages do not add up to $100 \%$ since not all possible RFEs and Es have been included in the Standard, while persons may also have more than one coding.

\begin{tabular}{|c|c|c|c|c|c|c|}
\hline \multirow{2}{*}{ 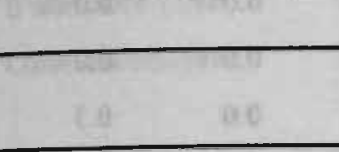 } & \multicolumn{3}{|c|}{$\%$ Reasons for Encounter } & \multicolumn{3}{|c|}{$\%$ Evaluations } \\
\hline & $\begin{array}{l}\text { group } A \\
\mathrm{n}=147\end{array}$ & $\begin{array}{l}\text { group B } \\
\mathrm{n}=78\end{array}$ & $\begin{array}{l}\text { group } C \\
n=1176\end{array}$ & $\begin{array}{l}\text { group } A \\
n=147\end{array}$ & $\begin{array}{l}\text { group } B \\
\mathrm{n}=78\end{array}$ & $\begin{array}{l}\text { group C } \\
\mathrm{n}=1176\end{array}$ \\
\hline $\begin{array}{l}\text { Psychological pro- } \\
\text { blems }\end{array}$ & $27.2^{\dagger}$ & $15.4^{\prime}$ & 7.8 & 12.9 & $16.7^{t}$ & 9.8 \\
\hline Digestive problems ${ }^{\circ}$ & $27.2^{+}$ & 17.9 & 18.4 & $25.2^{+}$ & 14.1 & 15.9 \\
\hline Hypertension ${ }^{\text {*.* }}$ & 14.3 & 12.8 & 11.2 & 14.3 & 12.8 & 11.2 \\
\hline Social problems ${ }^{\cdots}$ & $8.2^{4}$ & 6.4 & 2.8 & $7.5^{\dagger}$ & $7.7^{\ddagger}$ & 3.2 \\
\hline Frequent accidents ${ }^{* .}$ & $6.8^{\dagger}$ & 3.8 & 3.0 & 15.0 & 15.1 & 9.4 \\
\hline Gastritis & 6.1 & 5.1 & 4.7 & $7.5^{+}$ & 6.4 & 3.7 \\
\hline Headache & 5.4 & 11.5 & 9.6 & 1.4 & 3.8 & 2.0 \\
\hline Fatigue, malaise ${ }^{\cdots}$ & $4.8 \quad$ & $6.4 ; 70$ & 6.4 & 2.0 & 2.6 & 2.3 \\
\hline Red eye & $3.4^{t}$ & 0.0 & 1.0 & 0.0 & 0.0 & 0.0 \\
\hline Excessive perspiration & $2.7^{+}$ & 2.6 & 0.6 & 0.0 & 1.3 & 0.3 \\
\hline Sexual problems & 2.0 & $3.8:$ & 0.6 & 2.0 & 2.6 & 0.6 \\
\hline Hyperventilation ${ }^{. * *}$ & 1.4 & 1.3 & 0.3 & 2.0 & 2.6 & 1.8 \\
\hline Weight change ${ }^{* . \bullet}$ & 1.4 & 0.0 & 0.8 & 1.4 & 0.0 & 0.7 \\
\hline Diarrhea & 1.4 & 2.6 & 1.6 & 0.7 & 0.0 & 0.4 \\
\hline $\begin{array}{l}\text { Muscular pain, weak- } \\
\text { ness }\end{array}$ & 1.4 & 1.3 & 1.3 & 15.6 & 16.7 & 14.6 \\
\hline Gout & $1.4^{\dagger}$ & 0.0 & 0.1 & $6.1^{\dagger}$ & 0.0 & 0.8 \\
\hline Fractures & $1.4^{+}$ & 0.0 & 0.0 & $2.7^{+}$ & 1.3 & 0.1 \\
\hline Reflux complaints & 0.7 & 2.6 & 1.0 & 0.0 & 0.0 & 0.9 \\
\hline Irregular heartbeat & 0.7 & $5.1^{\ddagger}$ & 1.0 & 1.4 & $3.8^{\ddagger}$ & 0.9 \\
\hline $\begin{array}{l}\text { Menstruation disturban- } \\
\text { ce }\end{array}$ & 0.7 & 0.0 & 1.7 & 0.7 & 0.0 & 1.4 \\
\hline Foetor alcoholicus ${ }^{\text {".. }}$ & 0.0 & 0.0 & 0.0 & 0.0 & 0.0 & 0.0 \\
\hline
\end{tabular}




\begin{tabular}{lllllll}
\hline Ulcus disease & 0.0 & 0.0 & 0.0 & 2.0 & 2.6 & 0.8 \\
\hline Palpable liver & 0.0 & 0.0 & 0.0 & 0.7 & 0.0 & 0.0 \\
Pancreatitis & 0.0 & 0.0 & 0.0 & 0.0 & 0.0 & 0.0 \\
Cardiomyopathy & 0.0 & 0.0 & 0.0 & 0.0 & 0.0 & 0.0 \\
Lung infection & 0.0 & 0.0 & 0.0 & 5.4 & 10.3 & 5.2 \\
Tremors & 0.0 & 0.0 & 0.1 & 0.0 & 0.0 & 0.0 \\
Peripheral neuropathy & 0.0 & 0.0 & 0.0 & 0.7 & 0.0 & 0.0 \\
\hline Hyperreflexia & 0.0 & 0.0 & 0.0 & 0.0 & 0.0 & 0.0 \\
Convulsions, epilepsy & 0.0 & 0.0 & 0.1 & 0.7 & 0.0 & 0.3 \\
Alcohol intoxication & 0.0 & 0.0 & 0.0 & 0.7 & 0.0 & 0.0 \\
Memory disturbance & 0.0 & 0.0 & 0.3 & 0.0 & 0.0 & 0.2 \\
Subfertility man & 0.0 & 0.0 & 0.0 & 0.7 & 0.0 & 0.0 \\
Bums, Scalds & 0.0 & 1.0 & 0.3 & 0.0 & 1.0 & 0.3 \\
Hypercholesterolaemia & 0.0 & 1.0 & 0.1 & 0.0 & 1.0 & 0.5
\end{tabular}

- : Not in the original Standard, but in a shorter list of important indicators together with

*: Not included in the sumscore of the Standard

*.*: Important indicators according to the Standard.

$\dagger \quad$ Significant difference between groups $A(n=147)$ and $B+C+$ non respondents $(n=1353)$ ( $p \leq 0.05$ one tailed Fisher-Exact).

t: Significant difference between groups $B(n=78)$ and $C(n=1176)(p \leq 0.05$ one tailed Fisher-Exact). 
Table 2: Mean RFE sumscores, $E$ sumscores and consultation rates for problem drinkers according to GPs (Group $A, n=147$ ), problem drinkers according to screening (Group $B, n=78$ ) and non-problem drinkers (Group C, $\mathrm{n}=1176$ ).

\begin{tabular}{llll}
\hline & Group $A,(n=147)$ & Group $B,(n=78)$ & Group $C, n=1176)$ \\
\hline RFE sumscore $( \pm S E)$ & $1.07(1.25)^{\dagger}$ & $0.86(0.96)^{t}$ & $0.57(0.87)$ \\
E sumscore $( \pm$ SE) & $1.14(1.10)^{\dagger}$ & $1.10(1.05)^{4}$ & $0.75(0.92)$ \\
Consultations/year & $3.16(2.42)$ & $3.00(2.03)$ & $2.85(2.10)$
\end{tabular}

t: Significant difference between groups $\mathrm{A}$ and $\mathrm{B}+\mathrm{C}+$ non respondents ( $n=1353)$ ( $\mathrm{p} \leq 0.05$ Mann-Whitney).

t: Significant difference between groups B and C ( $p \leq 0.05$ Mann-Whitney). 
Table 3a: Sensitivity, specificity, positive predictive value (PPV), negative predictive value (NPV), odds ratio and Fisher-Exact p-value at different cut-off points for RFEs and Es from known problem drinkers $(n=147)$ versus those regarded by the GPs as nonproblem drinkers $(n=1353)$.

\begin{tabular}{lcccccc}
\hline & sens & spec & PPV & NPV & OR & p value \\
\hline RFE, cut-off point 0 & 59.9 & 59.8 & 13.9 & 93.2 & 2.20 & 0.0000 \\
RFE, cut-off point 1 & 28.6 & 87.1 & 19.4 & 91.8 & 2.71 & 0.0000 \\
RFE, cut-off point 2 & 10.9 & 95.5 & 20.8 & 90.8 & 2.59 & 0.0022 \\
RFE, cut-off point 3 & 4.1 & 98.7 & 25.0 & 90.4 & 3.16 & 0.0243 \\
RFE, cut-off point 4 & 2.0 & 99.6 & 37.5 & 90.3 & 5.62 & 0.0357 \\
E, cut-off point 0 & 68.7 & 47.7 & 12.5 & 93.3 & 2.00 & 0.0001 \\
E, cut-off point 1 & 27.9 & 81.4 & 14.0 & 91.2 & 1.69 & 0.0062 \\
E, cut-off point 2 & 12.9 & 94.4 & 20.0 & 90.9 & 3.15 & 0.0014 \\
E, cut-off point 3 & 2.7 & 98.2 & 13.8 & 90.3 & 1.46 & 0.3148 \\
E, cut-off point 4 & 1.4 & 99.6 & 25.0 & 90.3 & 3.72 & 0.1444 \\
\hline
\end{tabular}


Table 3b: Sensitivity, specificity, positive predictive value (PPV), negative predictive value (NPV), odds ratio and Fisher-Exact p-value at different cut-off points for RFEs and Es from unrecognized problem drinkers $(n=78)$ versus non-problem drinkers $(n=1176)$.

\begin{tabular}{lcccccc}
\hline & sens & spec & PPV & NPV & OR & p value \\
\hline RFE, cut-off point 0 & 55.1 & 60.4 & 8.4 & 95.3 & 1.87 & 0.0053 \\
RFE, cut-off point I & 23.1 & 87.9 & 11.3 & 94.5 & 2.18 & 0.0062 \\
RFE, cut-off point 2 & 6.4 & 95.7 & 9.1 & 93.9 & 1.54 & 0.2533 \\
RFE, cut-off point 3 & 1.3 & 98.8 & 6.7 & 93.8 & 1.08 & 0.6205 \\
RFE, cut-off point 4 & 0.0 & 99.7 & 0.0 & 93.8 & - & 0.8246 \\
E, cut-off point 0 & 69.2 & 49.1 & 8.3 & 96.0 & 2.17 & 0.0011 \\
E, cut-off point 1 & 25.6 & 82.7 & 8.9 & 94.4 & 1.64 & 0.0489 \\
E, cut-off point 2 & 11.5 & 95.3 & 14.1 & 94.2 & 2.66 & 0.0114 \\
E, cut-off point 3 & 3.8 & 98.6 & 15.0 & 93.9 & 2.70 & 0.1231 \\
E, cut-off point 4 & 0.0 & 99.7 & 0.0 & 93.8 & - & 0.7250 \\
\hline
\end{tabular}


Figure 1: Receiver Operating Characteristic (ROC) curves. Series 1 and 2 represent curves of RFE and E, respectively, for known problem drinkers compared with non-problem drinkers according to GPs. Series 3 and 4 represent curves of RFE and E, respectively, for hidden problem drinkers compared with non-problem drinkers.

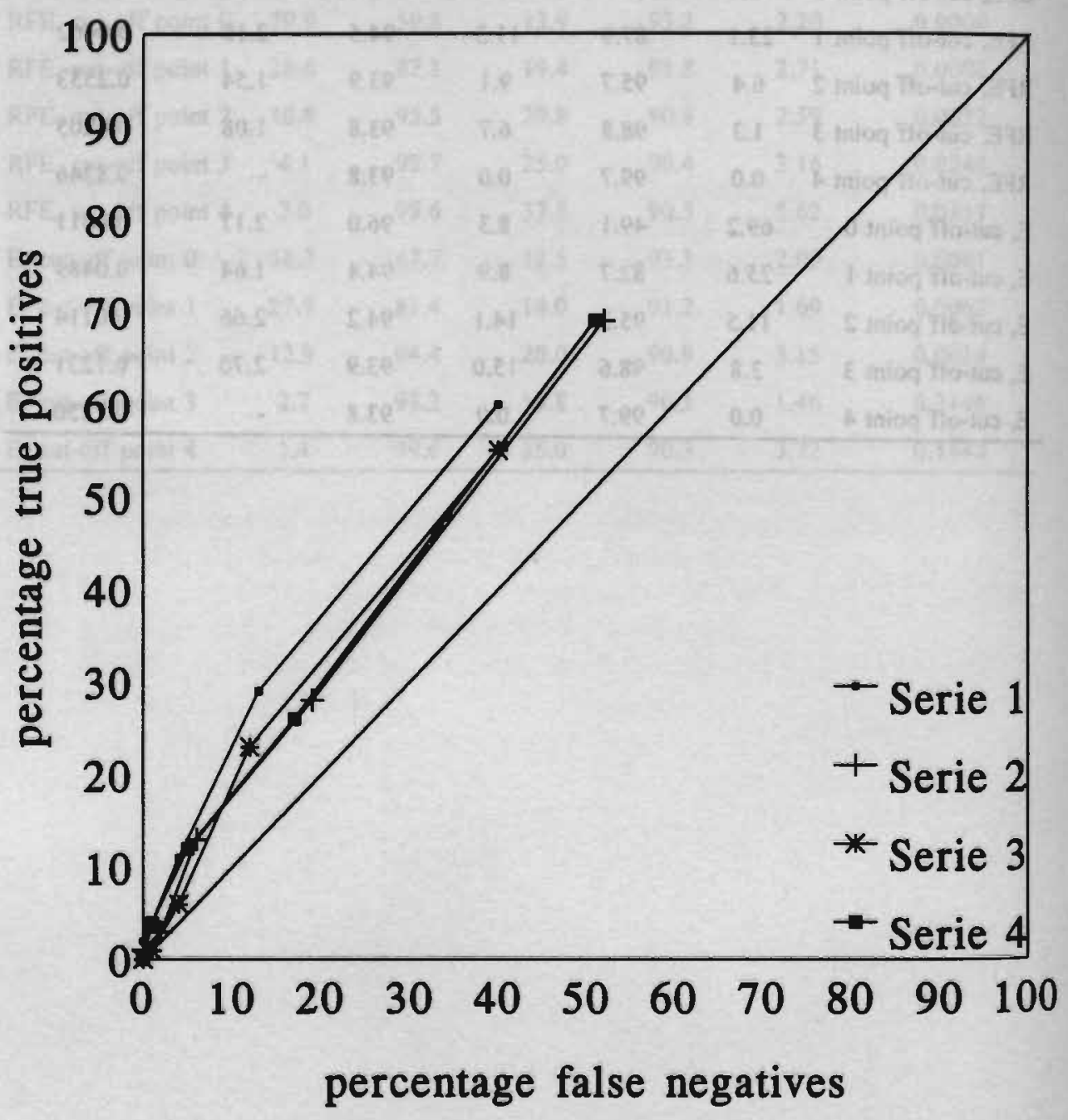


Appendix

Social problems

Psychological problems

Fatigue, malaise

Hyperventilation

Excessive perspiration

Weight change

Foetor alcoholicus

Reflux complaints

Gastritis complaints

Ulcus disease

Diarrhea

Palpable liver

Pancreatitis

Hypertension

Cardiomyopathy

Irregular heartbeat

Pulmonary infection

Headache

Tremors

Peripheral neuropathy

Muscular pain, weakness, atrophy

Hyperreflexia

Convulsions, epilepsy

Alcohol intoxication

Memory disturbance

Gout

Fractures

Sexual problems
Z01-Z29

P01-P99, except P15,P16

A04 (general weakness, tiredness, ill-feeling)

R98 (hyperventilation)

A09 (sweating problems)

T07 (weight gain), T08 (weight loss)

D29 (only if specified)

D03 (heartburn), D84 (if reflux oesophagitis)

D02 (stomach pain), D87 (if gastritis)

D85 (duodenal ulcer), D86 (other peptic ulcer)

D11 (diarrhea)

D96 (hepatomegaly)

D99 (only if specified)

K86 (uncomplicated hypertension)

K84 (only if specified)

K04 (palpitations, awareness of heartbeat), K05 (other abnor$\mathrm{mal} /$ irregular heartbeat/pulse), K78 (atrial fibrillation/flutter), K79 (paroxysmal tachycardia), K80 (ectopic beats, all types).

R78 (acute bronchitis/bronchiolitis), R81 (pneumonia).

N01 (headache)

N06 (only if specified)

N99 (only if specified)

L18 (myalgia), L19 (only if specified), L99 (only if specified).

N99 (only if specified)

N07 (convulsions), N88 (epilepsy)

PI6 (acute alcohol abuse)(not included in sumscore)

P20 (disturbance of memory/concentration/orientation)

T92 (gout)

L72-L76 (fracture specified, other)

P07/08 (inhibition/loss/lack of sexual desire/excitement /fulfilment), Y07/08 (symptoms/complaints sexual potency/function) 
Subfertility man

Menstruation disturbance

Burns, Scalds

Red eye

Hypercholesterolaemia

Frequent accidents

Digestive problems
Y10 (infertility, subfertility)

X05-X08 (menstruation absent/scanty/excessive/irregular/frequent/other

\section{S14 (burns/scalds)}

F02 (red eye)

T93 (lipid metabolism disorder)

A80 (accident/injury), F75-79 (contusion/abrasion/blackeye/ foreign body in eye/other injuries eye), L72-76 (see above), L77-L81 (sprains \& strains joints/dislocations/other injury musculoskeletal system), N79-N81 (concussion, other head injury), S14-S19 (burns/scalds/foreign body skin contusion/laceration/cut/other injury to skin or subcutaneous tissue)

\section{D01-D99}




\section{Chapter 7}

\section{General discussion and conclusions}

In this chapter the main findings of this study will be summarized in relation to the research questions mentioned in the introduction. Methodological limitations and strong points will be discussed, and the findings will be compared with the literature. Conclusions and practical implications of the results will be specified. Finally, recommendations for further research will be given.

\section{Main research questions}

It is not easy for general practitioners (GPs) to diagnose problem drinkers. Some of the major problems in the detection of persons with problematic drinking behaviour are that doctors tend to stereotype problem drinkers, that most doctors are not trained to handle and treat problem drinkers, that patients do not want to be labelled as problem drinkers and that there are no adequate diagnostic tools for the early detection of problem drinkers. These factors have been extensively discussed in the second chapter of this thesis.

Several strategies enhance the recognition of problem drinkers in general practice: training GPs, influencing patients and developing instruments for detection. These three stategies will be briefly discussed.

First, training of GPs. In the Netherlands, continuing medical education for general practitioners is given by outpatient alcoholism clinics (Center for Alcoholism and Drugs, $\mathrm{CAD}$ ) and by the 'Netherlands Institute for the development and support of general practice and primary health care' (Stichting O\&O), which has started a project called 'Signalering Problematisch Alcoholgebruik' (Detection of problem drinking). The Dutch College of General Practitioners develops 'Standards' for general practice. One of these 'Standards' deals with the detection and treatment of problem drinking'. These guidelines are widely distributed under Dutch GPs and some of them have already been combined with modules for continuing medical education. Medical school curricula do not pay a great deal of attention to substance abuse.

In addition to GP training, patients could be educated in order to facilitate 
recognition of problem drinking by GPs. Patients can be made less anxious to be labelled as alcoholics by providing them with information about problem drinking, and they can be informed about the negative consequences of alcohol consumption. Perhaps they will be able to recognize their own problems in relation to alcohol consumption. Information could be provided to large groups in society, for instance at school or on television.

The third option is the development of instruments for the detection of problem drinkers in general practice. Laboratory markers and questionnaires are not useful as first step procedures in the detection of problem drinkers. The first show poor test characteristics (low sensitivity and specificity), while the latter do not fit in with the working style of the GP.

The main aim of the present study was to find whether information obtained by GPs during normal practice can be used to identify problem drinkers. This information could be used to select patients with a high risk of problem drinking, who could then be asked in more detail about alcohol related problems.

The following research questions were studied:

1. Is it possible to construct a screening instrument on problem drinking in a general practice population, based on existing screening questionnaires?

2. What is the prevalence of problem drinkers among patients who visit their GPs over a one year period?

3. How many of these problem drinkers are recognized by the GPs?

4. Can unrecognized problem drinkers be distinguished on the basis of background variables?

5. Can unrecognized problem drinkers be distinguished on the basis of reasons for encounter (RFEs) and diagnoses (evaluations, Es)? 


\section{Main findings}

The above questions can be answered by summarising the main findings of the study.

An interval scale was constructed on the basis of existing screening instruments and some additional questions. The scale proved to be Rasch homogeneous, which implies that it is unidimensional and can measure problem drinking at the interval level. The scale can also be used with a fixed cut-off point.

Depending on the instrument used, the prevalence of problem drinking in our GP population ranged from $6 \%$ (CAGE) to $8 \%$ (MAST, SAAST). Applying a Rasch score $\geq 3$ as a criterion, the prevalence of problem drinking was found to be $7 \%$. There was good agreement between the four instruments, with kappas between 0.76 and 0.82 . Applying a Rasch score $\geq 3$ as a criterium, it was found that $10 \%$ of the problem drinkers defined as such were recognized by the GPs.

It appeared that in the category of patients who were not problem drinkers according the to GPs, background data like gender, age, smoking, life events and chronic social problems were useful in selecting persons at greater risk of problem drinking. In this category of patients who were not problem drinkers according to the GPs, the prevalence of problem drinking on the basis of the Rasch scale with the above-mentioned criterion was $6 \%$ (pretest probability). However, a 30-year old man who smokes, has experienced a life event during the past year and has a score of 5 on the social problem list, has an estimated $42 \%$ post-test probability of being a problem drinker.

RFEs and Es can be used, but have a very low sensitivity and specificity. A score on RFEs and Es was constructed using the 'Dutch Alcohol Standard'. Using various cut-off points, the maximum positive predictive values were $11 \%$ and $14 \%$ for RFE and E, respectively.

The Receiver Operating Characteristics (ROC) curves in chapters 5 and 6 clearly show that the basic variables like gender and age lead to a better ROC curve than reasons for encounter and diagnoses. 


\section{Methodological considerations}

\section{Limitations}

Although the study population as a whole includes more women than men, it contains relatively few female problem drinkers (in the response group, 13 hidden and 25 known female problem drinkers versus 69 hidden and 97 known male problem drinkers). It is questionable to what extent the results are reliable and externally valid for female problem drinkers. Interaction terms with gender were studied in the fourth logistic model presented in chapter 5. Only three terms (sleeping-pills, smoking, consumption level) were found to be significant. This could be due to the small number of female problem drinkers. For the efficiency of the study, it would perhaps have been better to exclude women. If the same group of GPs had only made a random selection among men, a 1 in 5 sampling fraction (from male patients not known as problem drinkers), instead of the 1 in 10 sampling fraction (from the total consulting population not known as problem drinkers), would have resulted in the same workload for GPs. The same number of patients, but only men, would have been included, so more hidden problem drinkers would have been detected. This would have resulted in more statistical power for the analysis in the group of male patients who were not problem drinkers according to the GPs. Since the number of female problem drinkers was very small and so, the results could not be very informative for the female population anyway, this would not have affected the external validity. The total number of known problem drinkers would have been lower: 97 men instead of 122 women and men known as problem drinkers would have responded to the questionnaire. Response to the questionnaire was highest in the group of those regarded as non-problem drinkers by the GPs and lower in the groups of those regarded as possible or certain problem drinkers by the GPs $(93 \%, 86 \%$, and $80 \%$ respectively). This demonstrates selective response: problem drinkers tend to have a lower response rate. Among the category of non-respondents, there will be a relatively higher proportion of problem drinkers than in the category of respondents. Prevalence estimates on the basis of the respondents will therefore result in an underestimation. This non-response phenomenon may also have affected the results in relation to characteristics of problem drinkers. Contrasts between groups will be smaller if the non-response is equally (randomly) distributed among subgroups in the categories of non-problem drinkers, hidden problem drinkers and known problem drinkers. If specific categories of drinkers, for instance female problem drinkers, show less 
response, there is a risk of distorted results (selection bias). The number of non-respondents was too small to find significant differences with the response group.

The design of this study does not allow conclusions about classification error or bias within the category of respondents.

It is clear from chapter 3 that not all consultations were registered by GPs. This affects inclusion as well as follow-up. Within the framework of this study, a maximum effort was taken to prevent registration bias. During the registration period all GPs were visited at least once every other week. Data were collected and problems in relation to the study discussed with the GPs. There was a simple random sampling procedure, embedded in normal practice, and clearly marked patient cards (for both patients included in and those excluded from the study) to remind the GPs of registration of consultations in the follow-up period.

An extensive data check was carried out with a patient-chart review of all patients included in the study. It could be concluded that patients were randomized in $72 \%$ of the first consultations and that $63 \%$ of the follow-up consultations were recorded. It is striking that so many consultations were not registered, in spite of the carefully designed procedures. There were no indications that the selection was biased. There was great similarity between recorded and non-recorded consultations among the group of patients who were selected at their first visit to the GP. Cards of patients not involved in the study were not reviewed. Therefore it cannot be excluded that certain categories of patients were excluded from the study through active selection by the GPs. However, there are no indications that this has occurred.

The most important comparison in this study was between hidden problem drinkers and non-problem drinkers. Inclusion of known problem drinkers in this study was important for estimating prevalence and for measuring how many PDs were recognized. In the study reported in chapter 5, the known problem drinkers were excluded from the analysis. The crude data on the most important variables included in the questionnaire, for the known problem drinkers, hidden problem drinkers and non-problem drinkers are given in the appendix of this thesis.

The conclusion that $10 \%$ of the problem drinkers are recognized needs some modification. The known problem drinkers were not a random sample from the whole population of problem drinkers: a greater proportion of the more serious problem drinkers was recognized. When a higher criterion on the Rasch score is chosen the percentage of known problem drinkers increases 
(applying the Rasch scale with a score $\geq 6$ as a criterion, $24 \%$ of the problem drinkers defined as such were recognized). It is possible that some of the patients defined as problem drinkers according to our criterion would not be considered problem drinkers by most GPs.

The numbers of patients in the various RFE and E categories were small, which could be criticized. However, our study on this scale corresponds to the population experience of one general practice in which all patients were followed for one year. Therefore, clinically significant differences important enough to be recommended to and used by GPs should have been found. Studies on an even larger scale would perhaps yield more statistically significant findings. These findings, however, would hardly be clinically relevant to general practitioners.

\section{Strong points}

The population studied is clearly defined. In the Netherlands patients have one GP. He/she keeps the files of the patient (mostly of the whole family), treats most medical problems and refers to a specialist only if he/she cannot handle the problem him/herself. Patients who visited their GP during a fixed one year period were eligible at their first visit within that period. All known problem drinkers and a 1 in 10 random sample of the patients who were not problem drinkers according to the GPs were included.

This study involved 16 general practices: some were situated in cities, other in more rural areas. The population studied is representative of at least the population of the south of the Netherlands.

At the above-mentioned first visit, the included patients received a questionnaire, to which a response of more than $90 \%$ was obtained.

Because all problem drinkers known as such by the GPs and a 1 in 10 sample of the rest of the population were included, there were eventually almost equal numbers of known and hidden problem drinkers. A larger sample fraction was decided against, to avoid too high a workload for the GPs.

General practitioners registered consultation data during or immediately after the consultation. This results in valid and precise consultation data. The influence of the study on the recognition of problem drinkers was small. During the one year observation period the 16 GPs newly recognized only 23 problem drinkers.

This is the first observational exploratory study on this scale in general practice in which hidden problem drinkers were compared with non-problem drinkers. Known problem drinkers were excluded from this part of the 
analysis. Wilkens performed a study involving the entire general practice population ${ }^{2}$. He separated groups on the basis of risk factors previously postulated (Alcohol At Risk Register). However, he did not study RFEs and Es at such a detailed level as we did. His classification of problem drinkers was based on the clinical view of alcohol dependence.

\section{Findings in relation to the literature}

Prevalence figures in this study were in the same range as those found in the other studies of comparable populations mentioned in chapter 1 .

The successful construction of the Rasch homogeneous problem drinking scale is remarkable. A previous clinical population study showed a good correlation between the Alcohol Dependence Scale (ADS), measuring the 'Alcohol Dependence Syndrome', and the MAST, which is more in line with DSM-III criteria $^{3}$. In that study both ADS and MAST performed well as screening tests for DSM-III alcohol disorders in a mixed substance abuse population. A high cut-off point of the MAST was recommended, indicating that severely addicted patients were involved. Correlation between MAST and ADS was 0.79 , indicating that the same concept was being measured on an interval scale. The present study in general practice shows that in a population of less addicted patients there is also a gradual difference in severity of drinking problems on a one-dimensional scale.

As was already mentioned in chapter 6 , there have been only a few studies of the characteristics of problem drinkers in general practice. Wilkens performed the most extensive study in general practice. He distinguished heavy drinkers, problem drinkers and alcohol addicts. Problem drinkers and alcohol addicts were defined as alcoholics, which yielded a prevalence of $1.8 \%$ when present and past drinking was accounted for and $1 \%$ for present drinking only. This low prevalence figure indicates that only patients with advanced drinking problems were studied. Wilkins' figures are difficult to compare with the figures from the present study, since he studied a selected population, viz. patients with one or more of his postulated risk factors. On the basis of his findings he constructed a 'Modified Alcoholic At Risk Register' with items that would help to select patients at risk. In this register, items are subdivided into 16 categories, for example physical diseases, mental diseases, alcoholic symptoms, occupations, work problems, accidents etc. The first two of these categories will be discussed and compared with results from the present study. As regards physical disease: peptic ulcer and gastritis were the most useful items. Of the various subcategories of physical disease, pancreatitis, cirrhosis 
of the liver, peripheral neuritis, tuberculosis, congestive heart failure, epilepsy and malnutrition were rare diagnoses (fewer than 4 patients included). Only obesity in man had some predictive value. Wilkens did not perform a statistical analysis to evaluate differences with a control group. In our study, gastritis was more prevalent in the category of known problem drinkers, while ulcus disease was too rare to result in significant differences. The subcategory of digestive problems was significantly more prevalent among known problem drinkers.

The second category of the Alcohol At Risk Register is mental diseases. Anxiety and depression were useful as discriminating factors, while attempted suicide and other mental diseases were rare. In our results, psychological problems also had predictive value, also in the category of hidden problem drinkers.

Buchan found $1 \%$ known problem drinkers, 92 men and 14 females, in a British health center, which is very close to our figures ${ }^{4}$. These known problem drinkers were characterized by a consultation rate of almost twice that for controls. We did not find this higher consultation rate. Problem drinkers in Buchan's study presented more gastrointestinal, psychiatric and accident related problems, which corresponds with what we found in the group of known problem drinkers. These problems were of limited value in the detection of hidden PDs. Buchan found a fourfold rise in social and interpersonal relationship problems, comparable with the 'chronic social problems' in our study. We found a higher score of these problems in the categories of hidden and known problem drinkers compared to non-problem drinkers (see appendix table 3 ). Similar findings were presented by Rush for two Canadian health centers ${ }^{5}$.

Skinner et al. emphasize the value of clinical measures for the detection of alcohol abuse ${ }^{6}$. Clinical examination provides better diagnostic accuracy than laboratory tests. The clinical signs presented in his study, in a rather selected study population, will only help in the late detection of problem drinking (tremor, spider naevi, rhinophyma, cigarette burns, tattoos etc.). Most of them were not present in our study population.

\section{Conclusions}

In a general practice population it is possible to measure problem drinking by means of an interval scale. This Rasch homogeneous scale was composed from existing problem drinking screening questionnaires and some additional 
questions. According to our criterion, $7 \%$ of the patients visiting their GP at least once over a one year period were problem drinkers. Of these PDs $10 \%$ are known as such to the GPs. Despite a possibly more restrictive definition used by GPs, and their hesitation to label patients as problem drinkers, most problem drinkers are not recognized by their GPs. They have no diagnostic means that they can easily use during normal practice.

It is possible to make a preselection of patients in general practice with a greater risk of problem drinking. These patients can be asked in more detail about their drinking. Patients especially at risk are men, those with chronic social problems or recent life events and smokers. RFEs and Es are less valuable for making a preselection. Patients with psychological, social and sexual problems and irregular heartbeat seem to be at relatively high risk.

\section{Practical implications}

The first practical implications to be discussed here are those concerning the Rasch scale. After validation of this scale in other populations, it will be possible to measure the severity of problem drinking on a scale of alcohol related problems, from light to heavy drinkers. This may be of value for screening and diagnostic purposes. The properties of the Rasch scale make it possible to ask patients about some isolated aspects of problem drinking and draw conclusions about other aspects. In other words, patients who respond positively to the more 'difficult' items (items that relate to more severe problem drinking) are likely to be serious problem drinkers. For instance, patients who 'drink in the morning' are likely to 'skip meals' or have 'felt the need to cut down on their drinking'. This property of the Rasch scale can be used for measuring in different populations. In a substance abuse population it is not necessary to ask the 'easiest' questions of the scale.

The detection of problem drinkers in general practice requires certain categories of patients in particular to be asked about their drinking behaviour. Especially at risk are male patients, smokers, patients with life events or social problems.

It is not efficient to use a long list of RFEs and Es for the detection of problem drinkers. Only psychological, social and sexual problems and irregular heartbeat have some predictive value. There are no specific signs for early detection of problem drinking, so the doctor will always have to be alert. 


\section{Recommendations for future research}

From the beginning of this study, the GPs who had to do the fieldwork played a major role in the decisions to be made about the study design and the practical performance of the study. The study design was simple, the protocol for the doctors was easy to follow and a system was developed to minimize the risk that the doctor would forget that he was involved in a study. The workload was entirely acceptable. During the one year observation period, doctors were visited every other week. Doctors reported that they were doing very well, and had no problems with inclusion and follow-up. During the observation period we did not check patient. records; this was done afterwards. In spite of the precautions, and notwithstancling the GPs' great dedication, they only recorded $63 \%$ of the follow-up consultations, while patients were included in $72 \%$ of the cases in which the protocol required this to be done. In the literature there is not much information about this sort of non-response. In his study about competence and performance of general practitioners, Rethans reported that GPs only scored $60 \%$ of the obligatory items of standards when observed during normal practice by simulated patients ${ }^{7}$. In future research projects it would also be interesting to observe the GPs with respect to their compliance with the research protocol.

The Rasch scale developed in this study was based on questionnaires that had mainly been validated in clinical populations, with some additional questions. Individually, the existing questionnaires were found not to be Rasch homogeneous. It would be important to test the new questionnaire on its Rasch properties in a comparable GP population, as well as in a clinical population. The Rasch scale showed that the 5 items most commonly admitted to were found to indicate mainly social or personal reactions to problem drinking, while the next 6 items refer to the more classical symptorns of excessive drinking, including loss of control. The last 7 items refer to dependence and serious health and social consequences of drinking. We supposed that this sequence of different problem areas corresponded to stages in a process. Studying this in more detail will require longitudinal data. This would perhaps also provide data about the process of recognition by the GPs. A longitudinal study of patients in general practice with different scores on the Rasch scale could also illustrate the 'natural course' of problem drinking. At this moment, it is not known how many of the mild problem drinkers develop a serious drinking problem. Perhaps future research could make it possible to select a group of patients at greater risk of developing more serious drinking problems. Until now, the effect of GP intervention alone has only been studied once, 
over a period of 1 year $^{3}$. Longterm effects of early intervention will also have to be studied in a longitudinal observation study. If these effects are really significant, these will stimulate GPs to recognize and treat problem drinkers. 


\section{References}

1. Van Zutphen WM, Van Olst EJ, Cornel M, Willink AE, Hoeksema HL. NHGstandaard 'Problematisch alcoholgebruik'. Huisarts \& Wet. 1990;33:280-5.

2. Wilkins RH, The hidden alcoholic in general practice. [dissertation]. London: Elec Science, 1974.

3. Ross RE, Gavin, Skinner HA. Diagnostic validity of the MAST and the Alcohol Dependence Scale in the assessment of DSM-III alcohol disorders. J Stud Alcohol 1990;51:506-13.

4. Buchan JC, Bucki EG, Deacon GLS, Irvine R, Ryan MP. Problem drinkers and their problems. J Roy Coll Gen Pract 1981;31:151-3.

5. Rush B, Brennan M. Is the health profile of problem drinkers different from that of other patients? J Fam Pract 1990;31:42-6.

6. Skinner HA, Holt $\mathrm{S}$, Sheu WJ, Israel Y. Clinical versus laboratory detection of alcohol abuse: the alcohol index. Brit Med J 1986;292:1703-8.

7. Rethans JJE, Van Boven CPA. De dokter onderzocht; simulatiepati ënten met mictieklachten op het spreekuur van de huisarts. Huisarts \& Wet. 1988;31:3-6.

8. Wallace $\mathrm{P}$, Cutler $\mathrm{S}$, Haines A. Randomised controlled trial of general practitioner intervention in patients with excessive alcohol consumption. Brit Med J 1988;297:663-8. 


\section{Summary}

Chapter 1 contains the general introduction to this thesis and discusses effects of alcohol consumption that could characterize problem drinkers. As definitions of alcohol related disorders give rise to confusion, the most important concepts of alcohol related problems are compared. Different measures of alcohol related problems and drinking are presented and prevalence figures based on different criteria are given.

The prevalence estimates based on screening appear to be higher than the $1 \%$ $2 \%$ registered problem drinkers by the general practitioners (GPs). This difference can be partly explained, but there remains a gap that might be ascribed to non-recognition by the GPs. Early recognition of problem drinking seems important, but the GP lacks necessary diagnostic tools. On this basis the main research questions are formulated.

Chapter 2 presents the results of a literature study on the limitations of recognizing problem drinking in general practice. Distinction is made between doctor-related factors (stereotyped ideas, lack of training, negative ideas about prognosis, anxiety about discussing drinking problems), patient- related factors (fear of being labelled an alcoholic, underreporting of alcohol consumption) and the lack of diagnostic instruments (laboratory tests inadequate for screening, questionnaires which do not fit in with the working style of the GP, most information available is derived from known problem drinkers in clinical populations). Recognition of alcohol-related problems at an early stage is valuable, and the effects of brief interventions at this stage seem to be positive.

The Dutch College of General Practitioners has developed a 'Standard' for the detection and treatment of problem drinkers. In this 'Standard' reasons for encounter and diagnoses, in combination with background data, are important tools for the recognition of problem drinkers. The medical problems selected and the background data used as predictors for problem drinkers are mainly based on research data from problem drinkers already known as such to physicians. So far no large scale investigations have been carried out that focus on problem drinkers not recognized as such by their general practitioner.

The following research questions were formulated: 
(1) Is it possible to construct a screening instrument on problem drinking in a general practice population, based on existing screening questionnaires? (2) What is the prevalence of problem drinkers among patients who visit their GPs over a one year period? (3) How many of these problem drinkers are recognized as such by the GPs? (4) Can unrecognized problem drinkers be distinguished on the basis of background variables? (5) Can unrecognized problem drinkers be distinguished on the basis of reasons for encounter and diagnoses?

A follow-up study was conducted in the practices of 16 GPs. Patients who had visited their GP at least once over a one year period were eligible for inclusion in the study. At their first visit, all problem drinkers known as such by the GPs $(n=153)$, plus a random sample of the rest of the practice population $(n=1384)$, received a questionnaire. Overall response rate was $91 \%$; response rate in the random sample of those regarded as non-problem drinkers by the GPs was $93 \%(n=1283)$. This questionnaire had two purposes: screening for problem drinking in the category of those regarded as non-problem drinkers by the GPs, and collecting information about background variables. Patients who were included were followed for the rest of that year by the GP, who registered all consultations on a specially designed registration form. Main variables were Reason For Encounter (RFE) and Evaluation/diagnosis (E), which were written down in free text and coded centrally according to the International Classification of Primary Care.

Chapter 3 motivates and describes the sampling procedure. A one in ten sample was taken from all patients who made a first visit to their GP during a one year period and who were not problem drinkers according to their GP. This sampling was necessary in order to achieve an acceptable level of effort for the GPs taking part in the research project. The sampling was done by the GPs themselves, during surgery hours, using a purpose-built 'random generator'. The sampling fraction deviated by less than $0.3 \%$ from $10.0 \%$. Every effort was made to motivate GPs. During the registration period all GPs were visited every other week, problems in relation to the study were discussed and data were collected. After the one year observation period file charts of 1473 patients could be retrieved to check the reliability of the sampling and registration procedure. A one in ten sample had been taken in $72 \%$ of the cases in which the protocol required this to be done, and $63 \%$ of the follow-up consultation had been recorded. An analysis of the non-recorded 
consultations showed great correspondence between those who had not been recorded and those who had been recorded for the study.

Chapter 4 describes the construction of the screening questionnaire. The questionnaire included the existing screening instruments CAGE, SMAST, SAAST and some additional questions. According to the Classical Test. Theory, the existing instruments, as well as the combination of all questions, formed a reliable scale with Cronbach's Alphas ranging from 0.75 to 0.93 . For the construction of an interval scale on problem drinking a Rasch analysis was performed. The Rasch analysis is a sophisticated scaling technique which aims to establish the unidimensionality of a set of questions. This analysis showed that 18 of the 28 questions in the complete screening list fitted a Rasch scale. CAGE, SMAST and SAAST were not Rasch-homogeneous.

Prevalence figures were estimated, taking into account the one in ten sample fraction of the group of those regarded as non-problem drinkers by the GPs. CAGE resulted in a prevalence figure of $8 \%$, SMAST and SAAST in $6 \%$. When a Rasch score $\geq 3$ was used as a criterion, the prevalence of problem drinking was found to be $7 \%$. With this scale as a criterion it was found that $10 \%$ of the problem drinkers were recognized by the GPs.

In analysing predictors of hidden PDs, the criterion of a Rasch score $\geq 3$ was chosen in order to separate hidden problem drinkers and non-problem drinkers in the category of patients who were not regarded as problem drinkers by the GPs. In the category of those not regarded as problem drinkers by the GPs $6 \%$ problem drinkers $(n=82)$ were detected.

Chapter 5 presents the results with regard to the predictive value of the background variables. Four levels of information were distinguished on the basis of availability to the GP. The first level contained basic patient characteristics like age and gender. The second level contained information obtainable from patient records, like life events and chronic illnes. The third model included smoking, and the fourth model included drinking. Logistic regression was performed with problem drinking as the dependent variable and four sets of predictors as independent variables. The differences between the four models were significant, with model 4 presenting the best prediction. In model 3 the most predictive variables were gender, life events, chronic social problems and smoking. It can be concluded that a pre-selection of patients with a greater risk of problem drinking can be made without information related directly to alcohol. Smoking men with chronic social problems and recent life events are 
especially at risk.

Chapter 6 describes the predictive value of the reasons for encounter (RFE) and evaluations (E) included in the 'Standard' developed by the Dutch College of General Practitioners. This was done for the prediction of known problem drinkers in the entire study population and for the prediction of hidden problem drinkers in the category of those not regarded as problem drinkers by the GPs. Of the 1537 patients included in the study, 1500 were followed for one year; 147 known problem drinkers and 1353 patients who were not regarded as problem drinkers by their GP. The latter category was found to include 78 hidden problem drinkers and 1176 non-problem drinkers (response rate $93 \%$ ). RFE and E sumscores were constructed, based on the 'Dutch Alcohol Standard'. Applying the RFE and E sumscores at various cut-off points resulted in significant Odds Ratios (ORs) for known problem drinkers versus the categegory regarded by the GPs as non-problem drinkers. For unrecognized problem drinkers ORs were only significant at low cut-off points. Predictive power was low in both situations. As far as individual RFE and $\mathrm{E}$ codes were concerned, significant differences were found between known problem drinkers and those who were non-problem drinkers according to the GPs for codes with regard to social problems, digestive problems, gout and fractures. Psychological problems, accidents, perspiration problems and red eye were only significant at the RFE level, while gastritis was significant at the $\mathrm{E}$ level. Differences in RFE and $\mathrm{E}$ between hidden problem drinkers and those regarded as non-problem drinkers by GPs were significant for irregular heartbeat and psychological problems. Sexual problems were significant at the RFE level, social problems at the E level.

It is concluded that RFEs and Es are of limited value in the detection of hidden problem drinkers.

Chapter 7, the general discussion and conclusions, first summarizes the main findings in relation to the research questions. Methodological limitations and strong points of the study are discussed.

A limitation of this study is that the results are of limited value for female problem drinkers, since the number of female problern drinkers in the study population was very small. Effects on the results of non-response by patients and of failures in the consultation registration are discussed. The design of the study does not allow conclusions about classification bias within the category of respondents. There are no indications of selective registration by the GPs. 
A strong point of the study was the clearly defined general practice population. The sampling procedure in the category of patients not regarded as problem drinkers by their GP, resulted in an acceptable workload for the GPs. This is the first observational study on this scale in general practice in which hidden problem drinkers are compared with non-problem drinkers.

Findings of the study are compared with the literature, and practical implications are discussed. Further exploration of the Rasch scale is advocated, in a general practice population as well as in a clinical population. It would also be interesting to illustrate the natural course of problem drinking in people with different scores on the Rasch scale. 


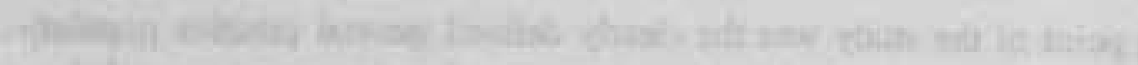

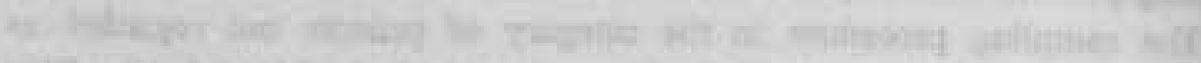

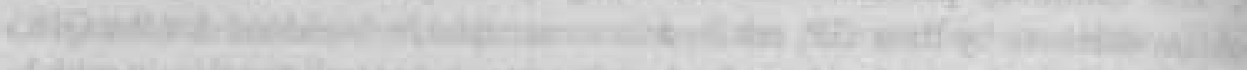

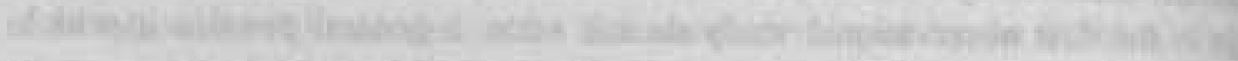

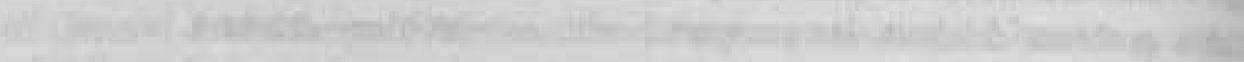

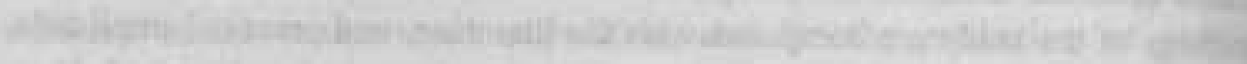

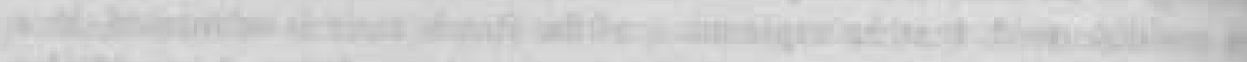

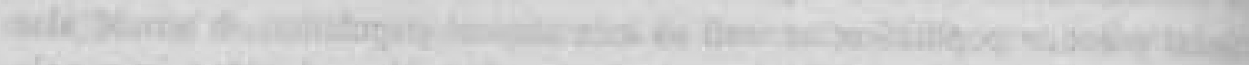

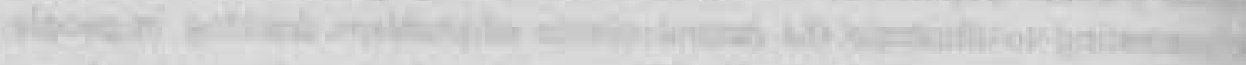

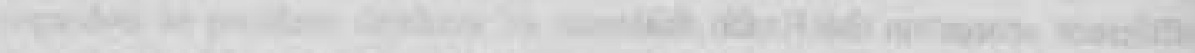

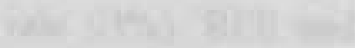

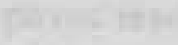

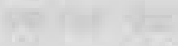

and

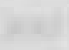

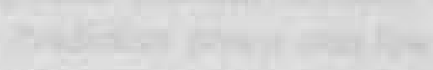

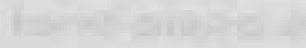

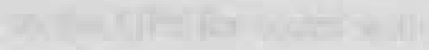

and

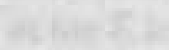

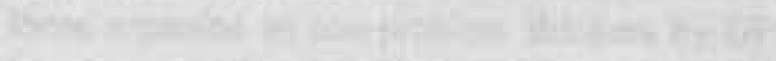

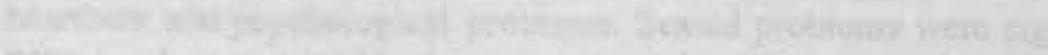

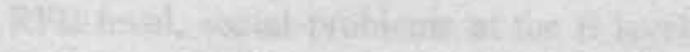

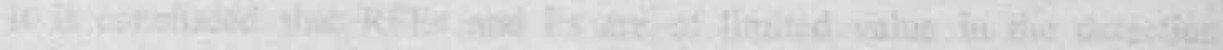
Whats

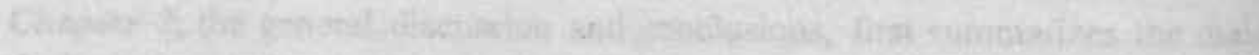

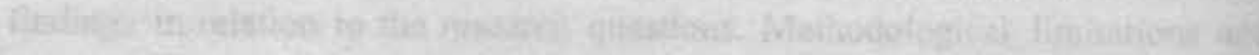

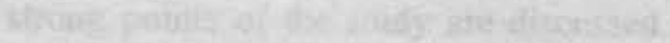

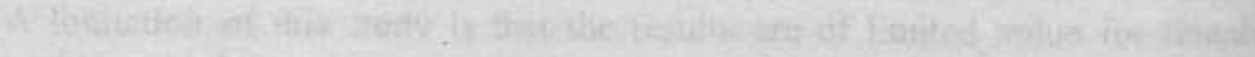

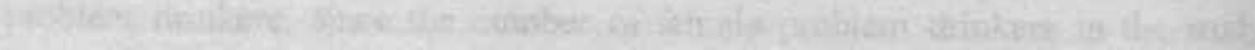

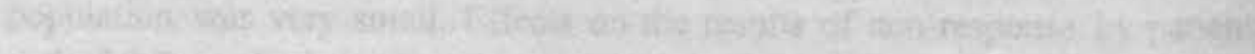

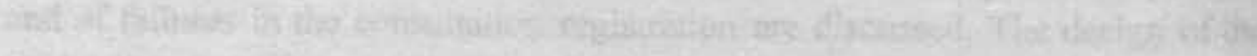

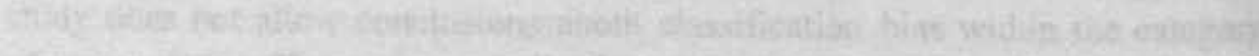

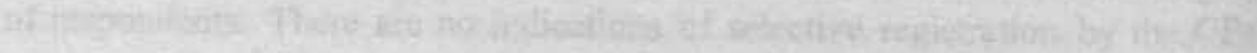




\section{Samenvatting}

Hoofdstuk 1 is de introductie van dit proefschrift. Effecten van alcoholgebruik die probleemdrinkers zouden kunnen kenmerken worden besproken. Definities van alcoholgerelateerde problemen geven aanleiding tot verwarring. Daarom worden de belangrijkste concepten vergeleken. Verschillende maten voor alcoholgerelateerde problemen en drinken worden gegeven met de prevalentie cijfers gebaseerd op deze criteria.

De prevalentiecijfers gebaseerd op screening blijken hoger dan de $1 \%-2 \%$ geregistreerde probleemdrinkers door huisartsen. Dit verschil kan ten dele worden verklaard, echter er blijft een verschil dat moet worden toegeschreven aan het niet herkennen van probleemdrinkers door de huisarts. De vroege herkenning van probleemdrinken lijkt belangrijk, echter het ontbreekt de huisarts aan diagnostische middelen. Op basis hiervan worden de hoofdvraagstellingen van het proefschrift geformuleerd.

Hoofdstuk 2 geeft de resultaten van een literatuurstudie naar de oorzaken van het niet herkennen van probleemdrinkers door huisartsen. Onderscheiden worden artsgebonden factoren (stereotypering, gebrek aan specifieke opleiding, negatieve inschatting van de prognose, angst probleemdrinken te bespreken), patiëntgebonden factoren (angst om als alcoholist te worden gekenmerkt, onderrapportage drankgebruik) en het gebrek aan diagnostische hulpmiddelen (laboratorium parameters niet geschikt voor screening, vragenlijsten passen niet binnen de werkwijze van de huisarts, de meeste gegevens zi.jn van bekende probleemdrinkers in een klinische setting). De herkenning van probleemdrinken in een vroeg stadium is waardevol en de effecten van 'korte interventie' in dit stadium lijken positief.

Het 'Nederlands Huisartsen Genootschap' heeft een standaard ontwikkeld voor de herkenning en behandeling van probleemdrinkers. In deze standaard vormen 'redenen van komst' en 'diagnosen', in combinatie met patiënt achtergrond variabelen een belangrijk handvat om probleemdrinkers te herkennen. De geselecteerde medische problemen en de achtergrond variabelen zijn hoofdzakelijk gebaseerd op onderzoeksgegevens betreffende bij artsen bekende probleemdrinkers. Tot nu toe is er geen grootschalig onderzoek verricht naar probleemdrinkers die niet als zodanig bekend zijn bij de huisarts.

De volgende onderzoeksvragen worden geformuleerd: 
(1) Is het mogelijk een screenings vragenlijst voor probleemdrinkers in een huisartsen populatie samen te stellen, gebaseerd op bestaande vragenlijsten? (2) Wat is de prevalentie van probleemdrinken binnen de populatie van patiënten die de huisarts minimaal $1 \mathrm{x}$ bezochten binnen een periode van 1 jaar? (3) Hoeveel van deze probleemdrinkers zijn als zodanig herkend door hun huisarts? (4) Kunnen niet herkende probleemdrinkers worden onderscheiden op basis van achtergrond variabelen? (5) Kunnen niet herkende probleemdrinkers worden onderscheiden op basis van 'redenen van komst' en 'diagnosen'?

Een follow-up studie werd verricht in 16 huisartspraktijken. Patiënten die hun huisarts minimaal $1 \mathrm{x}$ bezochten in een observatieperiode van een jaar konden worden ingesloten voor het onderzoek. Bij het eerste consult binnen de observatieperiode werden alle bekende probleemdrinkers $(n=153)$ en een random steek van de overige patiënten geïncludeerd $(n=1384)$. Deze patiënten ontvingen een vragenlijst. Overall response was $91 \%$, response in de random steekproef uit patiënten die volgens de huisartsen geen probleemdrinker waren, bedroeg $93 \%(n=1283)$. De vragenlijst had twee functies. Ten eerste het opsporen van probleemdrinkers in de categorie niet-probleemdrinkers naar het oordeel van de huisartsen, ten tweede het verzamelen van informatie betreffende achtergrond variabelen. De ingesloten patiënten werden het resterende deel van de observatieperiode door de huisartsen gevolgd. De huisartsen registreerden alle consulten op een registratie formulier. Belangrijkste variabelen waren 'reden van komst (RFE) en diagnose/evaluatie (E), deze werden door de huisartsen opgeschreven en centraal gecodeerd volgens de International Classification of Primary Care (ICPC).

Hoofdstuk 3 geeft de verantwoording en beschrijving van de random steekproef procedure. Een één op tien random steekproef werd getrokken uit alle patiënten die voor het eerst het spreekuur bezochten gedurende de éénjaars observatieperiode en die volgens de huisarts geen probleemdrinker waren. Deze steekproeftrekking was noodzakelijk om te komen tot een acceptabele onderzoeksbelasting voor de huisarts. De steekproeftrekking werd door de huisartsen zelf verricht met behulp van een speciaal ontworpen 'random generator'. De steekproeffractie week minder dan $0.3 \%$ af bij een ingestelde fractie van $10 \%$.

Huisartsen werden intensief begeleid om een optimale motivatie te krijgen. Tijdens de registratieperiode werden de huisartsen om de week bezocht, 
problemen met betrekking tot de studie werden besproken en gegevens werden verzameld. $\mathrm{Na}$ het registratiejaar werden de kaarten van 1473 patiënten bekeken om de betrouwbaarheid van de steekproef trekking en de registraties te controleren. De een op tien steekproeftrekking bleek te zijn verricht in $72 \%$ van de gevallen waar dit volgens protocol moest, $63 \%$ van de follow-up consulten was geregistreerd. Bij analyse van de niet geregistreerde consulten bleek dat deze grote gelijkenis vertoonden met de voor het onderzoek geregistreerde consulten.

Hoofdstuk 4 beschrijft de ontwikkeling van de vragenlijst voor de opsporing van probleemdrinkers. De vragenlijst bevat de bestaande vragenlijsten CAGE, SMAST, SAAST en enkele aanvullende vragen. Volgens criteria van de Klassieke Test Theorie vormen de genoemde instrumenten en de combinatie van alle vragen betrouwbare schalen met Cronbach's Alphas tussen de 0.75 en 0.93 . Om een intervalschaal te ontwikkelen werd een Rasch analyse verricht. De Rasch analyse is een geavanceerde techniek om de ééndimensionaliteit van een combinatie van vragen vast te stellen. Uit de analyse bleek dat 18 van de totaal 28 vragen van de vragenlijst een Rasch homogene schaal vormden.

Prevalenties werden geschat na een correctie van de een op tien steekproeffractie in de groep niet probleemdrinkers volgens de huisartsen. De CAGE gaf een prevalentie van $8 \%$, SMAST en SAAST $6 \%$. Als de Rasch schaal met een score van $\geq 3$ als criterium werd toegepast, bedroeg de prevalentie van probleemdrinken $7 \%$. Met dit criterium voor probleemdrinken bleek dat $10 \%$ van de probleemdrinkers bij de huisartsen bekend waren. Het criterium van de Rasch schaal $\geq 3$ werd gekozen om te onderscheiden tussen verborgen probleemdrinkers en niet probleemdrinkers (in de groep patiënten die geen probleemdrinker waren naar het oordeel van de huisarts), bij de analyses naar predictoren voor verborgen probleemdrinkers. In de groep niet probleemdrinkers naar het oordeel van de huisartsen bedroeg de prevalentie van probleemdrinken $6 \%(n=82)$.

Hoofdstuk 5 geeft de resultaten betreffende de predictieve waarde van de achtergrondvariabelen. Vier informatie niveaus werden onderscheiden op basis van beschikbaarheid voor de huisarts. Het eerste niveau bevatte onder andere geslacht en leeftijd. Het tweede niveau bevatte tevens informatie waarvoor de patiëntenkaart zou moeten worden geraadpleegd zoals life events en langdurige sociale problemen. Het derde niveau bevatte ook informatie betreffende roken 
en het laatste niveau over drinken. Analyses werden verricht met behulp van logistische regressie met probleemdrinken als afhankelijke variabele en variabelen van bovengenoemde 4 informatie niveaus als onafhankelijke variabelen. Verschillen tussen de vier modellen waren significant, met model 4 als beste predictie model. Als informatie over drinken werd uitgesloten, waren de meest predictieve variabelen: geslacht, life events, chronische sociale problemen en roken. Geconcludeerd werd dat een voorselectie kan worden gemaakt van patiënten met een grotere kans op probleemdrinken zonder informatie over drinken. Rokende mannen met langdurige sociale problemen en recente life events hebben een grote kans op probleemdrinken.

Hoofdstuk 6 beschrijft de resultaten betreffende de predictieve waarde van reasons for encounter (RFE) and evaluaties (E) genoemd in de 'Standaard' die is ontwikkeld door het 'Nederlands Huisartsen Genootschap'. Analyses werden verricht voor het voorspellen van bekende probleemdrinkers in de gehele studiepopulatie en voor het voorspellen van verborgen probleemdrinken in de groep patiënten die geen probleemdrinker waren naar het oordeel van de huisartsen. Van de 1537 patiënten die werden ingesloten in de studie werden er 1500 een jaar lang door de huisartsen gevolgd, 147 bekende probleemdrinkers en 1353 patiënten die gen probleemdrinker waren volgens de huisartsen. De laatste groep bestond uit 78 verborgen probleemdrinkers en 1176 nietprobleemdrinkers (response rate 93\%). RFE en E somscores werden samengesteld op basis van de 'Alcohol Standaard'. De RFE en E somscores gaven bij verschillende cut-off points significante Odds Ratios (ORs) voor bekende probleemdrinkers versus niet probleemdrinkers naar het oordeel van de huisartsen. Voor niet herkende probleemdrinkers versus niet probleemdrinkers waren de ORs alleen significant bij lage cut-off points. De predictieve waarde was laag in beide situaties.

Voor de aparte RFE en E codes werden verschillen gevonden tussen bij de huisarts bekende probleemdrinkers en de overige patiënten voor sociale problemen, gastrointestinale problemen, jicht en fracturen. Psychologische problemen, ongelukken, problemen met zweten en rode ogen waren alleen significant op RFE niveau, gastritis op E niveau.

Verschillen in RFEs en Es tussen verborgen probleemdrinkers en niet probleemdrinkers waren significant voor onregelmatige hartslag en psychologische problemen. Sexuele problemen waren significant op RFE niveau, sociale problemen op E niveau.

Er kan worden geconcludeerd dat RFEs en Es slechts van beperkte waarde zijn 
voor het opsporen van nog niet bekende probleemdrinkers.

In hoofdstuk 7, de algemene discussie en conclusies, worden de belangrijkste resultaten samengevat in samenhang met de onderzoeksvragen. Methodologische beperkingen en sterke punten van deze studie worden besproken. Een beperking van de studie is dat de resultaten beperkte geldigheid hebben voor vrouwelijke probleemdrinkers omdat hun aantal erg laag was in de studiepopulatie. Effecten op de studieresultaten van de non-response van de patiënten en het niet registreren van consulten door de artsen worden besproken. Het design van de studie laat niet toe een schatting te maken van de omvang van classificatie bias binnen de categorie van respondenten. Er zijn geen aanwijzingen voor selectieve registratie door huisartsen.

Een sterk punt van deze studie is de goed omschreven populatie van de huisarts. De steekproefprocedure binnen de groep patiënten die geen probleemdrinker waren naar het oordeel van de huisartsen resulteerde in een acceptabele werklast voor de huisartsen. Dit is de eerste observationele studie op grotere schaal binnen een huisartsen populatie waarbij verborgen/niet bekende probleemdrinkers worden vergeleken met niet probleemdrinkers.

Resultaten van deze studie worden vergeleken met de literatuur, praktische consequenties worden gegeven. Verdere exploratie van de Rasch schaal wordt bepleit, in zowel een huisartsen populatie als een klinische populatie. Het zou tevens interessant zijn het natuurlijk beloop te bestuderen van probleemdrinken voor personen met verschillende scores op de Rasch schaal. 


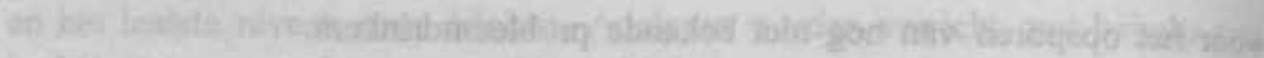

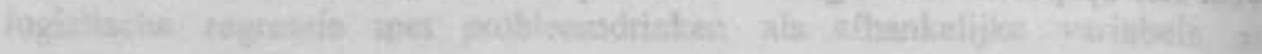

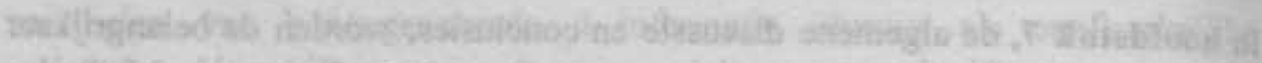

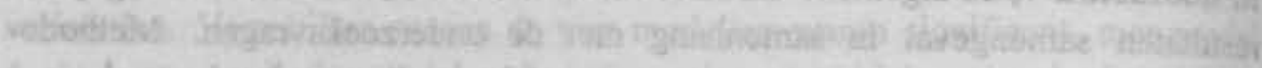

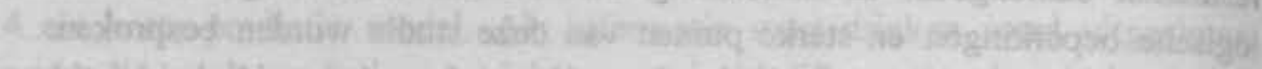

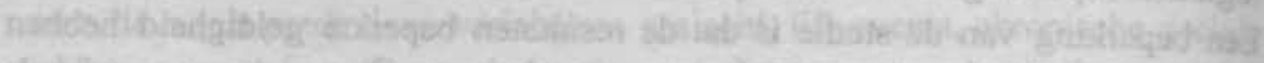

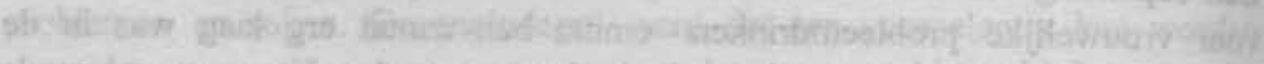

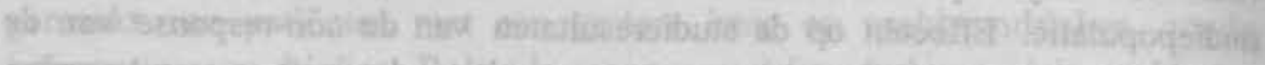

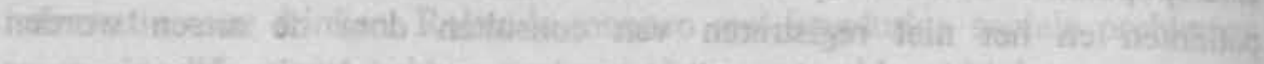

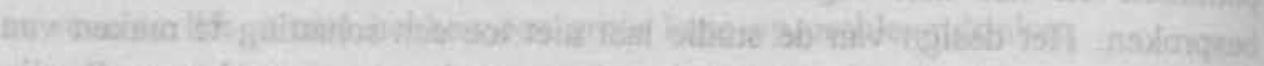

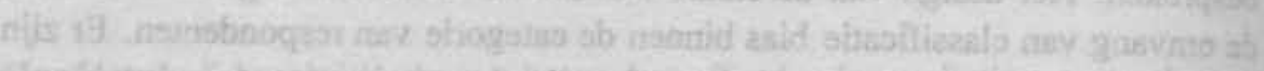

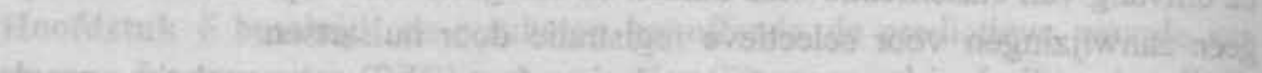

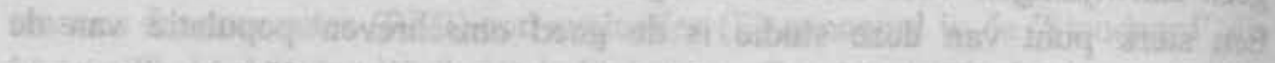

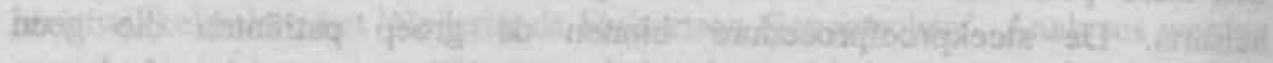

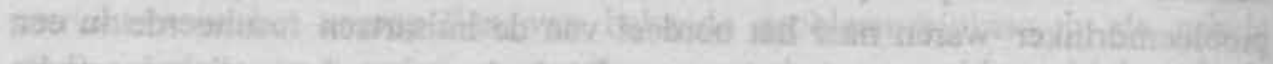

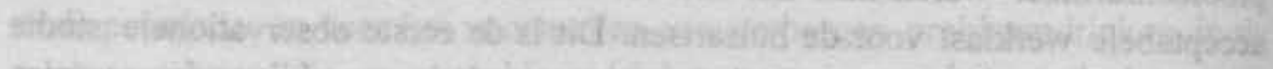

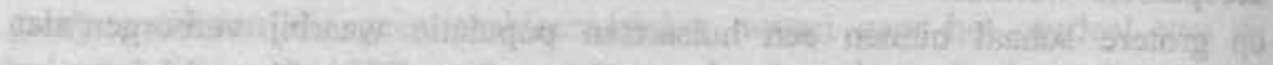

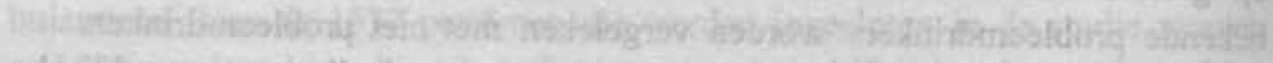

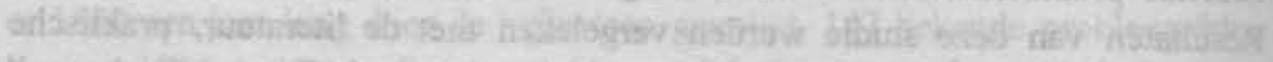

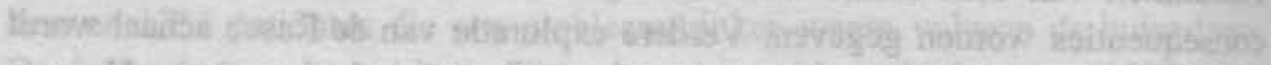

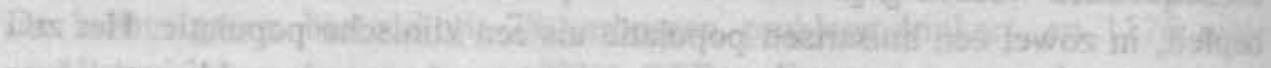

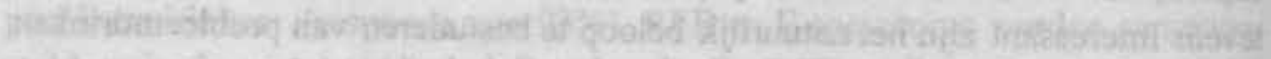

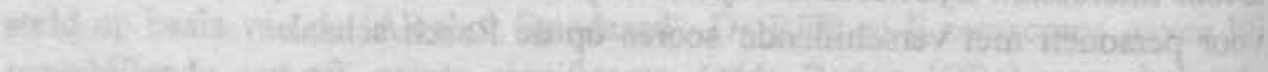

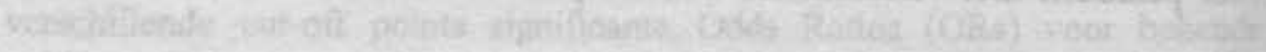

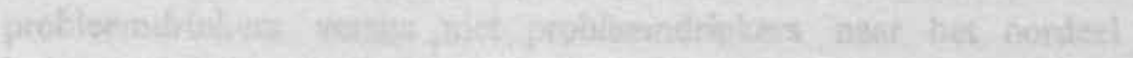
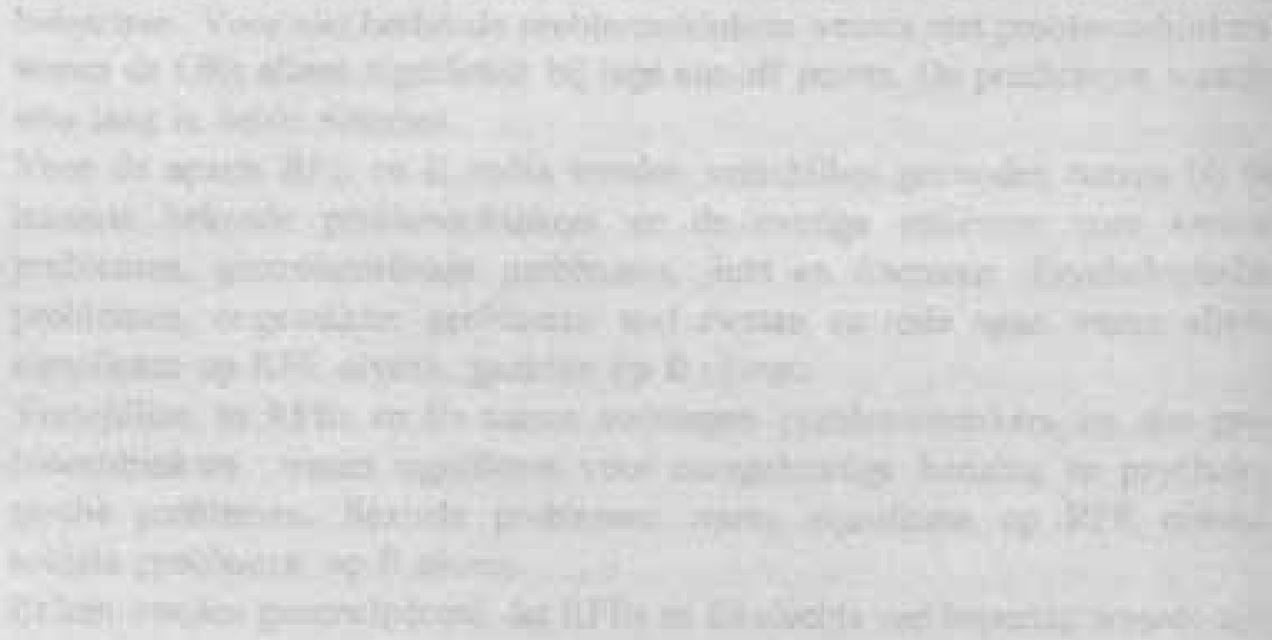


\section{Dankwoord}

Dit proefschrift is ontstaan dankzij een samenwerking tussen de vakgroepen medische sociologie en huisartsgeneeskunde. Wim van Zutphen ben ik veel dank verschuldigd als initiator van dit project. Hij stelde in samenwerking met Prof MJ Drop de subsidieaanvraag voor het onderzoeksproject op. Wim was altijd bereid met mij van gedachten te wisselen. Door zijn plotseling overlijden kan hij de afronding van het onderzoek niet meemaken. Riet Drop heeft als promotor mij regelmatig geestelijk geprikkeld met haar kritische opmerkingen/kanttekeningen, zij heeft gepoogd mij meer dan één schrijfstijl te leren. Ronald Knibbe (co-promotor) wil ik bedanken voor zijn rustige, weloverwogen inbreng. Na het overlijden van Wim als co-promotor, is deze plaats ingenomen door André Knottnerus, die zich zeer snel had ingewerkt. Mede door zijn stimulerende invloed bij het schrijven is de afrondende fase van het proefschrift relatief vlot verlopen. Silvia Bours was onmisbaar tijdens de data verzamelingsperiode in de contacten met de huisartsen, zij heeft gezorgd voor een 'foutloze' data invoer. Trudie Seegers heeft veel energie gestoken in het maken van een invoerprogramma voor de data, wij hebben hierbij levendig gediscussieerd. Ook Paula Rinkens heeft hierbij geholpen.

Het onderzoek was niet mogelijk geweest zonder de inzet van de huisartsen PGJ van Aubel, HJ Berendsen, HMJ Boesten, LWJ Bongenaars, P Bergmans, A van Deelen, MM Dirx, AGTH van Hoof, HMJ Jochems, PHM Passage, H Schiffers, AJC Schlösser en MCM Thomassen, die patiënten motiveerden voor het onderzoek en consulten registreeerden. De 1537 patiënten mag ik niet bij naam noemen, hen dank ik ook voor de medewerking.

Herman van Rens wil ik bedanken voor zijn stimulerende invloed, hij bracht mijn theorie dichter bij de praktijk. Job Metsemakers heeft mij goed geholpen bij het inwerken in de ICPC coderingen. Jan Geilen en Peter Bungenstock hebben geholpen bij het maken van de 'Random Generator', deze heeft feilloos gewerkt.

Wim de Vries en Nico van Oosten waren regelmatig bereid met mij mee te denken en een mening te geven uit een andere hoek. Bedankt voor jullie positieve inbreng.

Dan wil ik tot slot de mensen van 'de gang' bedanken voor hun gesprekspartnerschap. Met name wil ik hierbij noemen Mark Brueuren, Ad de Bruyne, Frank Buntinx, Geert-Jan Dinant, Paul Höppener, Frans van der Horst (m.n. de laatste loodjes), Jan-Willem de Jonge, Jean Muris, Victor Kaiser, Saskia 
Mol, Piet Portegijs, Richard Starmans, Jelle Stoffers, Jan-Joost Rethans, Annemie Wesselingh, Trudy van de Weyden, George Wolffs. 


\section{Appendices}

-abbreviations

-manual for general practitioners

-form for consultation registration

-questionnaire

-questions of Rasch scale, with Dutch translation 


\section{Abbreviations}
ADS Alcohol Dependence Scale
CAGE
Cut down, Annoyed, Guilty, Eye opener
CI
Confidence Interval
DSM-III Diagnostic and Statistical Manual of mental disorders
E Evaluation = diagnosis
ICPC International Classification of Primary Care
ICD International Classification of Diseases
GP General Practitioner
MALT Münchener Alcoholismus Test
MAST Michigan Alcoholism Screening Test
n number
NPV Negative Predictive Value
NWO Nederlandse organisatie voor Wetenschappelijk Onderzoek
OR Odds Ratio
PD Problem Drinker
PPV Positive Predictive Value
RFE Reason For Encounter
ROC Receiver Operating Characteristic
SAAST Self Administered Alcoholism Screening Test
SADQ Severity of Alcohol Dependence Questionnaire
SCR SCReening
SD Standard Deviation
SE Standard Errror
SMAST Short MAST 
HANDLEIDING ONDERZOEK RIJKSUNIVERSITEIT IIMBORG WDAR

GEZONDHEID, DAGELIJKSE PROBLEAMIAN WN

ALCOHOLGEBRUIK

\section{BELANGRIJESTE PUNTEN}

Betreffende patienten die nog geen sticker op de kaart hebben:

* Iedere bekende/herkende probleemdrinker ;

- blauwe sticker plakken

- toestemming vragen

- nummer op vragenlijst controleren

- toelichting geven vraag 23

- vragenlijst meegeven

- pat. formulier invullen en alfabetisch op naam opbergen

* Iedere andere patiënt ouder dan 15 jaar op knop drukken ,

A. patient valt niet in de steekproef (groen lampje)

B. patient valt wel in de steekproef (rood lampje)

$$
\begin{aligned}
& \text { Indien } A_{i} \text { - } \\
& \text { groene sticker op kaart plakken } \\
& \text { patient valt niet in het onderzoek } \\
& B_{i} \text { - } \\
& \text { - } \text { - toeste sticker plakken } \\
& \text { - nummer op vragenlijst controleren } \\
& \text { - toelichting geven vraag } 23 \\
& \text { - vragenlijst meegeven } \\
& \text { - pat. formulier invullen en alfabetisch } \\
& \text { op naam opbergen }
\end{aligned}
$$

\section{Betreffende patienten die al wel een eticker hebben,}

* Als dit een groene sticker is blijft patiěnt buiten het onderzoek vallen ( $U$ hoeft dus bij een volgend consult van deze patiënt niet op de knop te drukken), tenzij $U$ ontdekt dat het toch een probleemdrinker betreft.

* Als patient een rode of een blauwe sticker heeft zit deze al in het onderzoek, het vervolgconsult is nu van belang;

- oude registratieformulier opzoeken

- registratie nummer van oude formulier overnemen op nieuw formulier

- nieuw formulier invullen

- opbergen achter oude formulier

- geen vragenlijst meegegeven. 
(deze informatie sluit aan bij de brief in de vragenlijst)

Puntsgewifs volgt hieronder de belangrifkste informatie, zoals die door $\mathrm{U}$ an de patiënt gegeven kan worden.

1. Ik doe als huisarts mee aan een onderzoek van de Rijksuniversiteit Limburg.

2. Dit onderzoek gaat over klachten van mensen, leefgewoonten en de rol die alcohol daarbij speelt.

3. Een aantal willekeurig gekozen patiënten doet mee aan het onderzoek.

(random apparaat evt. laten zien)

4. Als patiënt moet $U$ een vragenlijst invullen.

Het is belangrijk dat U deze vragenlijst invult.

$U$ kunt de enquête thuis zelf invullen en wilt U deze dan in de gratis antwoordenveloppe terugsturen naar de Universiteit?

5. Klachten waarmee $U$ op het spreekuur komt worden op anonieme wijze aan de Universiteit doorgegeven. 
Toelichting opzet ondergoek.

zoals U reeds bekend is worden in het onderzoek drie hoofdgroepen patienten onderscheiden, te weten;

- De bij U bekende probleemdrinkers

- De niet bekende probleemdrinkers

- De niet-probleemdrinkers.

Het onderzoek betreft patienten die in de onderzoeks periode op het spreekuur komen.

Niet al deze patienten vallen in het onderzoek. Orn praktische redenen is hiervoor gekozen. De patienten die in het onderzoek vallen zijn alle probleemdrinkers bij $\mathrm{U}$ bekend, ook indien deze in de onderzoeksperiode door $U$ worden herkend, en een steekproef uit alle overige personen ouder dan 15 jaar. Deze laatste groep zal voor het grootste deel uit niet-probleemdrinkers bestaan maar ook voor een deel uit bij U niet bekende probleemdrinkers.

Deze drie groepen patienten zullen met elkaar worden vergeleken met: als belangrijkste doel on een beter zicht te krijgen op de groep niet herkende probleemdrinkers.

De vragenlijst dient als 'gouden standaard' om te bepalen of iemand probleemdrinker is of niet. Deze moet aan alle patienten die in het onderzoek vallen $1 \mathrm{x}$ worden meegegeven. In de vragenlijst worden ook een aantal vragen gesteld betreffende patiëntachtergrondvariabelen. 


\section{Practische uitvoering.}

Bij een patiënt die op het spreekuur komt zijn er een aantal mogelijkheden.

\section{1: De patiënt 1s een probleemdrinker.}

Deze patiënt valt in het onderzoek. U plakt een blauwe sticker op de kaart en vraagt de patiënt of hij aan het onderzoek wil meewerken. De ervaring leert tot nu toe dat dit bijna niet wordt geweigerd. Indien de patiënt toch niet wil meedoen zet U een streep door de sticker (graag wel het registratieformulier (zie bijlage) invullen, zonder naam en adres).

$U$ moet controleren of het nummer op de vragenlijst hetzelfie is als het nummer op het registratieformulier dat los in de vragenlijet zit.

Vragenlijst aan de patiênt geven. Vraag 23 van de vragenlijst behoeft enige toelichting voor de patiënt. Uit het proefonderzoek is gebleken dat het door $U$ zelf invullen van de dagen in het schema plezierig is voor de patient en de response bevordert.

Het verdient aanbeveling het registratieformulier direct na het consult in te vullen. Het kan hierna op alfabetische volgorde op naam worden opgeborgen in de door ons geleverde klapper. De formulieren moeten alfabetisch worden opgeborgen omdat deze bij een volgend consult in de onderzoeksperiode makkelijk moeten kunnen worden teruggevonden.

2: De pat1ënt 19 volgeng 0 geen probleemdrinker look de patienten die volgens $U$ misschien een probleemdrinker zijn vallen hieronder).

Indien de patiënt ouder is dan 15 jaar drukt $U$ op de knop om te bepalen of de patient in de steekproef valt.

* Als het groene lampje gaat branden zit de patiēnt niet in de steekproef, U plakt een groene sticker op de kaart. Als de patiént een volgende keer op het spreekuur komt blijft de patiënt buiten het onderzoek.

* Als het rode lampje gaat branden zit de patient in het onderzoek. U moet een rode sticker op de kaart plakken en de patiént vragen aan het onderzoek mee: te werken.

De procedure verloopt verder hetzelfde als onder 1 . 


\section{3: De patiënt heeft een blauwe sticker op de kaart.}

Het betreft hier een bekende probleemdrinker die eerder in de onderzoeksperiode op het spreekuur was. Omdat we ook geinteresseerd zijn in de vervolgconsulten in de onderzoeksperiode is ook deze patiënt voor het onderzoek van belang.

De patiënt krijgt geen nieuwe vragenlijst mee. U kunt wel informeren of hij de lijst die het vorige consult is meegegeven heeft teruggestuurd. (evt nieuwe lijst meegeven uit rode bakje)

Er moet wél een nieuw registratieformulier worden ingevuld. Dit ligt los in het rode bakje. Patiënt reg. nr. invullen! Het nieuw ingevulde registratieformulier achter het oude opbergen.

\section{4: De patient heeft een rode sticker op de kaart.}

Het betreft hier iemand die volgens $U$ geen probleemdrinker is én al eerder in de onderzoeksperiode op het spreekuur is geweest én aan het onderzoek meedoet.

Dok deze patiënt krijgt geen nieuwe lijst mee naar huis, wel informeren of de lijst de vorige keer is teruggestuurd.

Er moet wél een nieuw registratieformulier worden ingevuld. Dit ligt los in het rode bakje. Patiênt reg. nr. invullen! Opbergen als onder punt 3 . Indien $U$ zoudt vinden dat deze patiënt toch een probleemdrinker is dan kunt $U$ dit aangeven op het registratieformulier en $\mathrm{U}$ moet een blauwe sticker op de kaart bijplakken. De patiēnt valt hierdoor in categorie 3 .

\section{5: De patiënt heeft een groene aticker op de kanrt.}

Dit is iemand die eerder in de onderzoeksperiode op het spreekuur was en niet in de steekproef viel. Ook nu kan de: patiênt niet in de steekproef raken.

Indien $U$ ontdekt dat de patiènt toch een probleemdrinker is gaat de procedure volgens 1 lopen. U kunt aangeven op het registratieformulier dat de patiênt nieuw opgespoord is en een blauwe sticker op de kaart bijplakken. 
Handleiding voor het invulien van het patientregiotratieformu11er

Dit formulier moet worden ingevuld bij iedere nieuwe patiënt die in het onderzoek valt en iedere patient die al in het onderzoek zit en voor een volgend consult komt.

- Patient nummer moet corresponderen met het nummer op de vragenlijst of met het nummer van het vorige registratie formulier. Dit nummer is al ingevuld bij een nieuwe patiẻnt en moet worden overgenomen van het oude registratieformulier bij een patiênt die al in het onderzoek zit.

- Naam en adres worden niet doorgedrukt op de copie (anonimiteit). Gaarne duidelijk invullen.

- Geslacht; man of vrouw omcirkelen.

Datum consult; contactdatum, 9-7 of 9 juli is voldoende.

Reden van komst; Hier moeten de klachten van de patiênt, zoveel mogelijk zoals de patiēnt ze formuleert, worden opgeschreven. Het betreft hier ook niet klachtgebonden redenen van komst zoals 'ik kom voor controle van de bloeddruk' of 'wilt U mijn bloeddruk eens controleren'. Als meerdere klachten tot én evaluatie/werkhypothese behoren kunt $U$ dat aangeven met een accolade. Indien meer dan 3 klachten per evaluatie/werkhypothese dan vult $U$ de 3 belangrijkste in.

- Evaluatie / Diaqnose; Vaak zullen klachten niet leiden tot een evaluatie. De reden van komst wordt dan herhaald als evaluatie (b.v. hoesten of pilrecept). Indien $U$ wel tot een evaluatie of diagnose komt wilt U die dan zo duidelijk mogelijk omschrijven.

- Vaag - niet vaag; Onder een vage klacht wordt een klacht verstaan waarbij de huisarts $z i c h$ geen duidelijk beeld kan vormen over het ontstaansmechanisme (hoofdpijn en algehele malaise zonder duidelijke aanknopingspunten is vaag, hoofdpijn t.g.v. stress op werk is niet vaag). De vaagheid kan in 4 gradaties worden aangegeven, varierend van zeer vaag tot zeer concreet. Per reden van komst moet dit worden aangegeven.

Somatikch - psychosociaal; per reden van komst moet worden aangegeven in hoeverre somatische dan wel psychosociale problematiek een rol speelt. Dit kan ook weer in 4 gradaties worden aangegeven. 
Aard van het contact; dit is van belang voor het bepalen van de episode.

Een patiënt waarvoor een formulier wordt ingevuld kan bij het betreffende consult 'nieuw in het onderzoek' worden betrokken of reeds in het onderzoek zitten.

'Nieuw in het onderzoek' zijn alle patienten die een vragenlijst meekrijgen, te weten; de bij U bekende probleemdrinkers die in de onderzoeksperiode voor het eerst op het spreekuur komen, de volgens $U$ niet probleemdrinkers die in de steekproef vallen en de patiënt met een groene sticker op de kaart die tijdens de onderzoeksperiode toch een probleemarinker blijkt te zijn.

Als de patiënt reeds in het onderzoek zit heeft deze een blauwe of rode sticker op de kaart.

De getallen 1 tot en met 5 hebben betrekking op de redenen van komst 1 tot en met 5 .

Nieuwe episode: De patiënt komt voor het eerst vanwege deze klacht en/of diagnose bij U. Herhaalcontact: De patiënt is al of niet tijdens de registratieperiode eerder vanwege dezelfde klacht bij U op het spreekuur geweest. Ex is dan sprake van één episode waarbinnen verschillende contacten vanwege dezelfde klacht(en) en/of diagnose(n) plaatsvinden. Periodieke controle: De patiënt komt om de zoveel weken/maanden bij U langs (b.v. bloedsuikercontrole, hypertensiecontrole).

Recidief: De patiënt komt na een klachtenvrije periode bij U met dezelfde klacht als voorheen. Hierbij is geen sprake van eenzelfde episode omdat de patient gedurende een periode geen klachten heeft gehad. Ook als de patiënt voor de registratieperiode al eens met dezelfde klacht kampte, wordt het contact als recidief genoteerd.

In het onderste vak kunt $U$ aangeven in hoeverre patient volgens $U$ een probleemdrinker is. Indien dit het geval is dan kunt $U$ aangeven of het een nieuw ontdekte probleemdrinker is, of het probleemdrinken is besproken en of de patiënt al dan niet ontkent.

Rechts onder is nog ruimte voor aanvullende opmerkingen. Wilt $U$ in dat vak uw paraaf of handtekening zetten? 


\section{Remindere.}

Het is de bedoeling dat mensen die na 2 weken de vragenlijst niet hebben teruggestuurd een reminder te sturen met een nieuwe vragenlijst. Om de anonimiteit te kunnen waarborgen moet deze brief uitgaan van de praktijk. Wij kunnen aan de praktijk doorgeven welke nummers nog niet zijn ontvangen. M.b.v. het originele registratie formulier is na te ga.an welke persoon bij welk nummer hoort. De reminder zou dan een briefhoofd van de huisarts moeten hebben en gesteld zijn vanuit de huisarts (In de trant. van;'Ik heb een aantal nummers van de Universiteit doorgekregen...')

Een concept van een dergelijke brief is toegevoegd.

Geachte mevrouw, meneer,

Onlangs heeft $u$ via mij een vragenlijst ontvangen over gezondheid, dagelijks functioneren en alcoholgebruik. Het grootste gedeelte van deze vragenlijsten is reeds teruggestuurd naar de

Rijksuniversiteit Limburg te Maastricht.

Ik heb van de Universiteit een aantal nummers van vragenlijsten ontvangen die nog niet zijn teruggestuurd. Uit onze administratie blijk.t dat het een vragenlijst van $U$ betreft.

Voor het onderzoek is het van belang dat alle vragenlijsten worden teruggestuurd.

$U$ kunt dit ondertussen hebben gedaan, dan kunt $U$ deze brief als niet ontvangen beschouwen.

Indien $u$ dit nog niet gedaan heeft verzoeken ik $u$ dit alsnog te doen. Daarvoor is het nog niet te laat.

Voor alle duidelijkheid:

Uw naam en adres zijn bij de onderzoekers niet bekend.

De vragenlijet is dus anoniem. Uw antwoorden op de vragen zullen mij niet tex kennis komen.

Hierbij een nieuw exemplaar van de vragenlijst voor het geval dat $u$ het andere exemplaar niet meer bij de hand heeft.

Mijn hartelijke dank 
onderzoek Rijksuniversiteit Limburg naar gezondheid, dagelijks functioneren en alcoholgebruik.

Geachte meneer

Zoals U waarschijnlijk weet doe ik samen met de Rijksuniversiteit Limburg te Maastricht een onderzoek naar gezondheid, dagelijks functioneren en alcoholgebruik.

Uit mijn gegevens blijkt dat ik U een vragenlijst heb meegegeven toen $U$ mijn spreekuur bezocht d.d. ......

De onderzoekers van de Universiteit hebben mij een aantal nummers van vragenlijsten doorgegeven met de daarbij behorende geboortedata.

Bij vergelijking tussen geboortedatum zoals die vermeld is in uw vragenlijst en mijn gegevens op uw patiëntenkaart blijkt dat dit verschillende geboortdata betreft.

Br heeft zich waarschijnlijk een misverstand voorgedaan wardoor een ander persoon de vragenlifst heeft ingevuld.

Ik zou het erg op prijs stellen als $\delta$ de vragenlifst alsnog zelf zou willen invulien. Ook als U geen alcohol gebruikt, zijn de gegevens van belang.

Voor alle duidelijkheid:

Uw naam en adres zijn bij de onderzoekers niet bekend. De vragenlijst is dus anoniem. Uw antwoorden op de vragen zullen mij niet ter kennis komen.

Bij voorbaat dank,
A.C.J. Schlösser
P.G.J. van Aubel 


\section{עax:}

Geb. datw:
Mres:

Geslacht: mo / vroun

Datu consult:

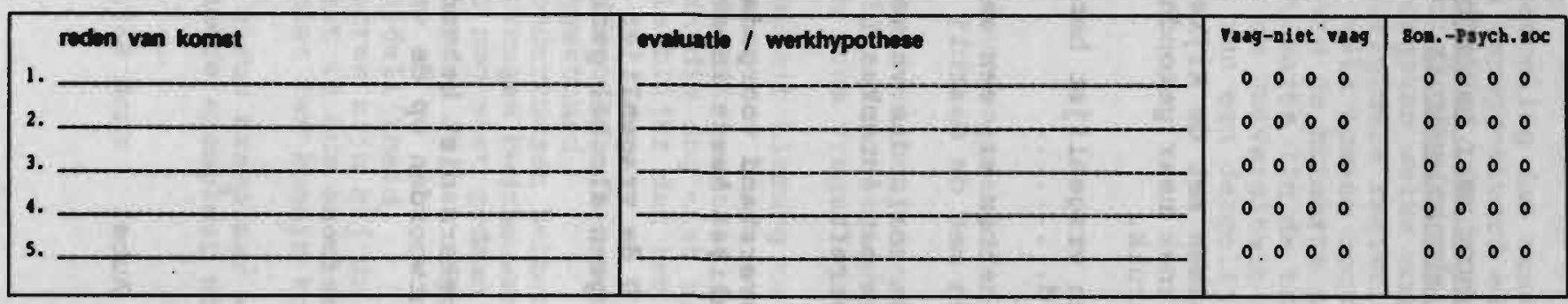

ard ven hat contect

- Patient nieum in onderzoek (vregenll jat neegeven)

rack (vregenli jat neegeven)

o patient reede in onderzoek (ond reglstratieforwulier opzoeken) $\quad 000000$ periadieke controle

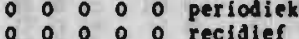

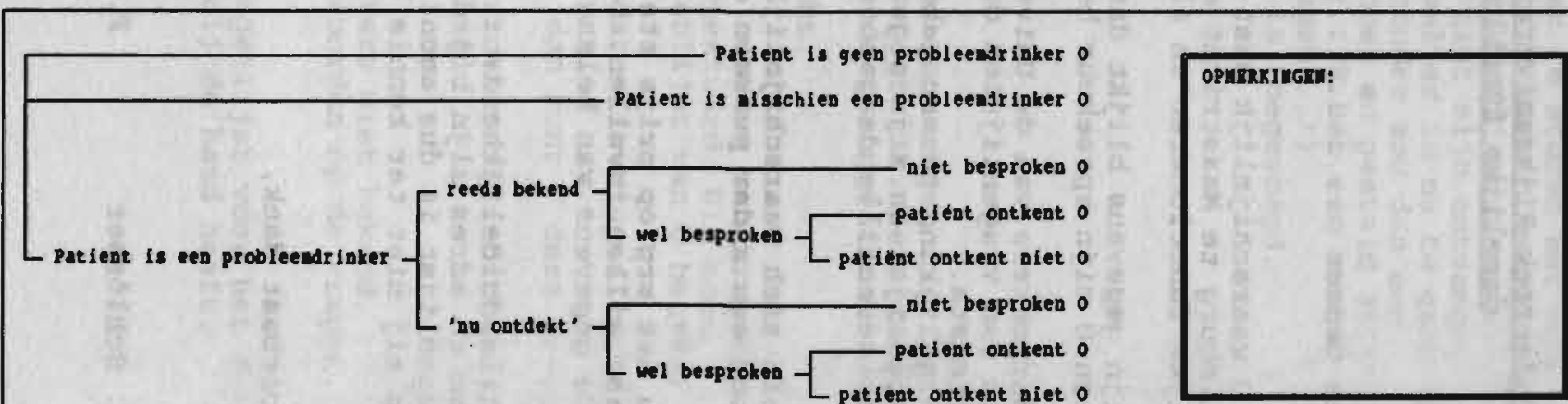




\section{Onderzoek Rijksuniversiteit Limburg naar gezoncheid, dagelijkse problemen en alcoholgebruik.}

Geachte mevrouw, meneer,

Uw huisarts doet in samenwerking met de Rijksuniversiteit Limburg een onderzoek naar gezondheid, dagelijkse problemen en het gebruik van alcoholhoudende dranken.

Dit onderzoek wordt gedaan an meer te weten te kamen over het verband tussen klachten waarmee mensen op het spreekuur komen en hun gezondheid.

Wij willen graag weten hoe u vindt dat uw gezondheid is, wat uw leefgewoonten zijn en welke problemen $u$ in uw dagelijks leven heeft.

Uw huisarts heeft voor dit onderzoek de medewerking nodig van zijn/ haar patiënten. Een aantal willekeurig gekozen patiënten wordt gevraagd an aan dit onderzoek mee werken. Dit betekent dat de keuze op $\mathrm{U}$ door het toeval bepaald is.

De onderzoekers van de Universiteit zijn ook huisartsen. Alle door u verstrekte gegevens vallen onder het Medisch Beroepsgeheim. Uw gegevens zullen dan ook volstrekt vertrouwelijk worden behandeld. Dit houdt cok in dat deze niet aan uw huisarts worden doorgegeven. (Indien $u$ dit wel wilt, kunt $u$ dit aan het einde van de vragenlijst aangeven.)

Wij verzoeken $u$ de vragenlijst in te vullen en in de bijgesloten antwoordenvelop naar de afdeling Huisartsgeneeskunde van de Rijksuniversiteit Limburg terug te sturen. Een postzegel plakken is niet nodig.

Bij voorbaat hartelijk dank voor uw medewerking.

Hoogachtend,

M. Cornel,

huisarts Rijksuniversiteit Limburg.

Tel: 043 - 882279 / 882273 


\section{Toelichting.}

Deze vragenlijst bestaat uit twee soorten vragen. Van beide soorten geven wij hieronder een voorbeeld.

1. U DTINT HIET JUISTE BOKJE AAN TB KRUISEN (PER VRAAG 1 BCWJ, TEREIJ DIT AUERS hOROT VERaEID)

Heeft een week 7 dagen ?

ja

nee

2. U DIENT HET JUISTE ANIWOORD OP DE SITIPPELCIJN IN TE VUIEN:

Hoeveel dagen heeft een week ? .......

Zoudt $\mathrm{u}$ de vragen willen beantwoorden in de volgorde zoals ze in de vragenlijst staan? Dit is van belang andat in de tekst aanwijzingen zijn opgenamen. Deze aamwijzingen geven aan welke vragen in uw geval kunnen worden overgeslagen.

Indien $\mathbf{u}$ de vragen in de verkeerde volgorde invult, mist $\mathbf{u}$ deze aanwijzingen.

Mochten ex onduidelijkheden zijn, dan kunt $\mathrm{U}$ overdag inlichtingen krijgen bij :

M. Cornel, huisarts of S. Bours, assistente telefoonnummer: $043-882279$ / 882273 


\section{Vragenll]st.}

1. MAT IS UW GEBOCRIEDATUM ?

$$
\text { (dag - maand - jaar) }
$$

2. HAT IS UW GESTACAT ?

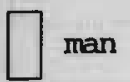

\section{BOB IS UN WOONVERRAN OP DIT MOMENT?}

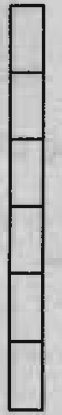

één persoons huishouden

alleen met partner

met partner en kind(eren)

alleen met kind(eren)

inwonend bij ouders

anders, namelijk

\section{WAT IS UA BURGERTIJKE STAAT ?}

gehuwd

samenwonend

nooit gehurd of nooit samenwonend geweest

gescheiden of niet meer samenwonend

weduwnaar of weduwe

anders, namelijk 


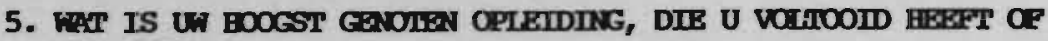
NOG VORGT ?

lagere school

lager beroeps onderwijs zoals huishoudschool, ambachtschool, L.H.N.O., L.T.S.

middelbaar algemeen onderwijs zoals MULO, MAVO

middelbaar bercepsonderwijs

voortgezet algemeen onderwijs

zoals HBS, MS, VHEO, HAWO, Atheneum, VWO

hoger beroepsonderwijs

wetenschappelijk onderwijs

Indien andere opleiding graag een amschrijving:

\section{WAT IS $\mathrm{NU}$ OP U VAN TOKPASSING ?}

(eventueel mserdere hokjes aankruisen)

ik heb betaald werk, 20 uur of meer per week

ik heb betaald werk, minder dan 20 uur per week

werkloos

arbeidsongeschikt, voor 808 of meer

arbeidsongeschikt, voor minder dan 808

gepensioneerd of in de vut

huisvrouw of $-\operatorname{man}$

studerend of schoolgaand, voor 20 uur of meer per week

militaire dienst of vervangende dienst

anders, namelijk 


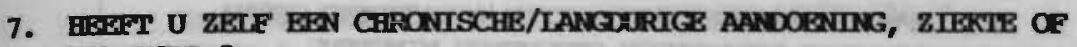
HANDICAP ?
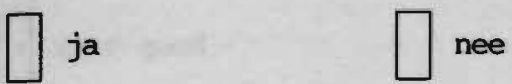

Zo ja, wellke?

8. HIEEFT UW PARITER EEN CHRONISCHE/LANGDURIGE AANDOENIIG, ZIEKTE OF BANDICAP ?

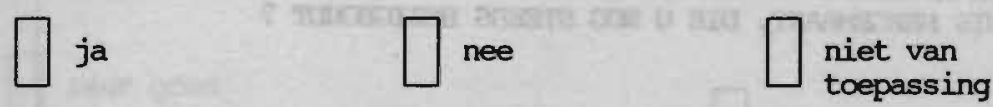

Zo ja, welke ?

9. HIEETT EEN VAN UN MINDERJARTGE KINDGREN (JONGER DAN 18 JAAR) EEN CHRONISCHE/LANGDURTGE AANDOEMIIG, ZIEWHE OF HANICAP ?

$\square$ ja $\square$ nee niet van toepassing

Zo ja, wellke? 


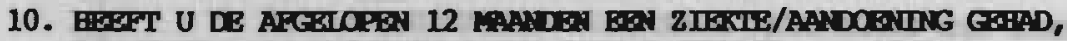
WAARDOOR U UN DAGEIIJKSE BEZIGHEDEN GEDUREND MTISTENS EEN MAAND NIET KON UTTVOBREN ?
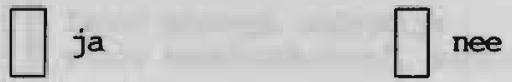

Zo ja, welke?

11. HEEET U DE AFGETOPEN JAFEN EEN RIGRTJEENE EN DRCEVIGE GEBBEURIEANIS MEFFEMAART, DIE U NOG SIEEDS BEZIGAOUDT ?<smiles>CCCCCCCCCCCCCCCCCCCCCCCC</smiles>

Zo ja, als $u$ dit wilt veomelden, welke gebeurtenis was dat ? 


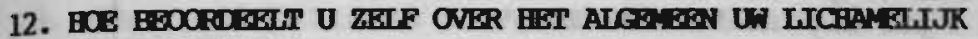
FUNCITOUEREN ?

zeer goed
goed
matig
slecht
zeer slecht

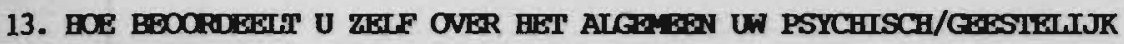
FUNCIIONEREN ?

zeer goed

goed

matig

slecht

zeer slecht

14. HOE VINOT U DAT U TECEN DE PROBIEYEN VAN HET DACELTIKS LEVEN BENT OPGEMASSEN ?

zeer goed

goed

matig

slecht

zeer slecht 
15. ROOKT U SIGAPEITEN, SHAG, PIJP OF SIGAREN ? (eventueel meerdere hokjes aankruisen;

bij minder dan 1 per dag "nee' aankruisen)

Nee

$\mathrm{Ja}$, ongeveer ....... sigaretten per dag

Ja, ongeveer ........ sigaren per dag

$\mathrm{Ja}$, ongeveer ....... pijpen per dag

16. GEBRUINT U WELL EENS STAAPTABIETHEN ?

ja nee, ga door met vraag 17

Zo ja, hoe vaak?

elke dag

5-6 keer per week

3-4 keer per week

1-2 keer per week

minder dan 1 keer per week

17. GEBRUIKUI U KEL EENS KAIMERTIESTABIEITEN ?

$\square$ ja nee, ga door met vraag 18

Zo ja, hoe vaak ?

elke dag

5-6 keer per week

3-4 keer per week

1-2 keer per week

minder dan 1 keer per week 


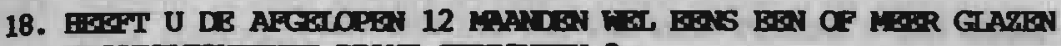
ATOOFO BOUDENDE DRARK GEDRONIEN?

(Dit betreft alle dranken die alcoholhoudend zijn zoals: bier, wijn, sherry, jenever, cognac enz.)

ja, ga door met vraag 23

nee, ga door met vraag 19

19. BEEFT' U DAARVOCR (VOOR DE AFGEIOPEN 12 MAANDEN) HEL EENS EEN OF MEAER GALEN ALCOAOLBOUDLNDB DRANK GEIRONKEN ?

ja, ga door met vraag 20

nee, ga door met vraag 56

20. BOEVERT JAAR GEIEDEN BENT U GESTOPT MET HET DRUNKEN VAN ALCOBOUBOUDENDE DRANEKEN?

jaar 
21. WAT IS DB FEDEA DAT U GESTOPT BENT MET BIST DRTNKEN VAN AIOOAOLAOUDENE DRALXEN?

medici.jngebruik

'ik vind het niet lekker meer'

'ik ga niet meer uit'

gezondheidsredenen

financiële redenen

anders, namelijk

22. DRCNK U HET EENS 6 OF MEER GAZEN ALCOBOLAOUDENDE DRANK PER KETER ?

ja nee, ga door met vraag 56

Zo ja,

A. BOEVEKLI GAAREN DROAK U DAN FER KRER ?

..... glazen

B. HOE VAAR DEED ZICH DAT WOOR PER MAND ?

...... keer

C. INDIEN ZICB DAT NIET IEDERE MAND VOARDED, GOSVAAK DEG ZICH DAT DAN VOCR PER JAAR ?

..... keer

Ga door net vraag 56 


\section{HOEVIIET, GLAZEN ALCOBOLAOUDENDB DRANR HIEKFT U DE AFGEIOPEN}

WIEKK GEDRONKKN ?

(Wilt $\mathrm{u}$ deze vraag ook imvullen als $\mathrm{u}$ weinig alcohol gebruikt)

Toelichting:

Omdat wij graag willen weten op welke dagen $u$ alcohol gebruikt vragen wij u onderstaand schema in te vullen.

- Wilt $u$ het eerst in de linker kolam de dagen van de week invullen.

$\mathrm{U}$ begint bij gisteren en u gaat terug in de week.

- Pas daarna vult u de rechter kolam in.

Weekdagen

\begin{tabular}{|c|c|c|}
\hline (gisteren) & $\begin{array}{l}\text { thuis } \\
\text { buitenshuis }\end{array}$ & $\begin{array}{l}\text {..... glazen } \\
\text {.... glazen }\end{array}$ \\
\hline (eergisteren) & $\begin{array}{l}\text { thuis } \\
\text { buitenshuis }\end{array}$ & $\begin{array}{l}\text {..... glazen } \\
\text {.... glazen }\end{array}$ \\
\hline ..... dag & $\begin{array}{l}\text { thuis } \\
\text { buitenshuis }\end{array}$ & $\begin{array}{l}\text {..... glazen } \\
\text {..... glazen }\end{array}$ \\
\hline ..... dag & $\begin{array}{l}\text { thuis } \\
\text { buitenshuis }\end{array}$ & $\begin{array}{c}\text {..... glazen } \\
\text {..... glazen }\end{array}$ \\
\hline ..... dag & $\begin{array}{l}\text { thuis } \\
\text { buitenshuis }\end{array}$ & $\begin{array}{l}\text {..... glazen } \\
\text {..... glazen }\end{array}$ \\
\hline ..... dag & $\begin{array}{l}\text { thuis } \\
\text { buitenshuis }\end{array}$ & $\begin{array}{l}\text {..... glazen } \\
\text {..... glazen }\end{array}$ \\
\hline ..... dag & $\begin{array}{l}\text { thuis } \\
\text { buitenshuis }\end{array}$ & $\begin{array}{l}\text {.... glazen } \\
\text {..... glazen }\end{array}$ \\
\hline
\end{tabular}


24. ALS U BET AANIAL GIAZEN ALCOBOLHOUDENDE DRAN VAN DE AFGELOPEN WESK BIJ EIKTAAR OPIKATI (vraag 23), IS DIT DAN EVENVERL ALS U

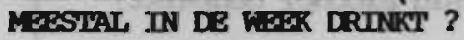

ja, dit is ongeveer evenveel

nee, gewoonlijk drink $i k$ meer.

ik drink meestal ...... (aantal) glazen per week

nee, gewoonlijk drink ik minder.

ik drink meestal ....... (aantal) glazen per week

nee, ik drink niet iedere week.

ik drink meestal ...... (aantal) glazen per maand

nee, $\mathrm{jk}$ drink niet iedere maand.

ik drink meestal ...... (aantal) glazen per jaar

25. DRTNKT U HER ENENS 6 OF MEER GLAEEN ALCOHOKHOUDENDE DRANT PER KEERR ?

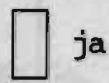

nee

zo ja,

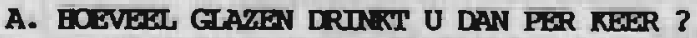

...... glazen

B. BOE VAAR DOBT ZICH DAT VOOR PER MAAND?

..... keer

C. INDIEN ZICH DIT NUET IFDERE MAAND VOORDOST, BOB VAAR DOET ZICH DIT DAN VOOR PER JAAR ?

keer 
26. HEGEFT U VROBEER (IANGER DAN 12 MAANDEN GETEDEN) WRL EENS; EKAN PERIODE GEFIAD, WAARIN U MEER DFONK DAN U BIJ VRAAG 24 BEEFT AANGEGEVEN ?

nee, ga door met vraag 27

ja, ga door met onderdeel A. $t / m$ C. van deze vraag

zo ja,

A. BOEVEET JAAR IS HET GETEDEN, DAT U GEMDDIR BENT MET HET DRTNKEN VAN ALCOBOT BOUDENDS DRANKEN ?

..... jaar

B. WAT WAS DE REDGN DAT U MINDER BENT GAAN DRTNKKIN ?

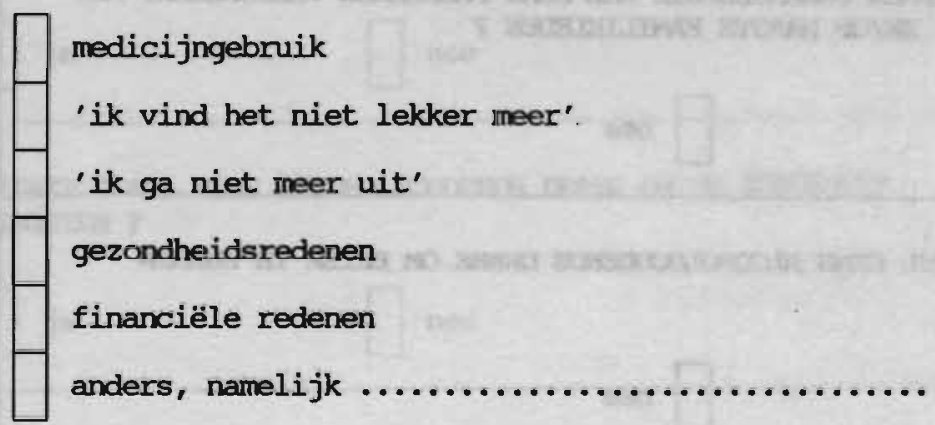

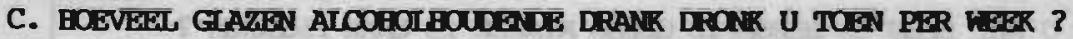
..... glazen 
27. VINUT U DAT U MERR ALCOAOIHOUDENDE DRANK GEBROIKT DAN DS MEESTE MENSEN?
$\square$ ja
nee

28. VINDEA UW PAFINER EN/OF FAMDIIELEDEN, VRIENDEN OF KENMISSEN, DAT U TEVEERT DRTNKT ?

$\square$ ja $\square$ nee

29. MAKEN UW PARINER EN/OF NAASIE FRHIIITEIEDEN ZICH WECL EENS ZOREEN OUER UW DRANKGEBRUIK, OF KIAGEN ZE ER WEL KENS OVER ?

$\square$ ja $\square$ nee

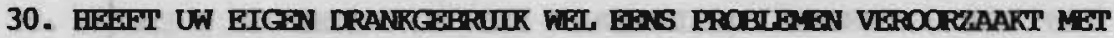
UW PARINERR EN/OF NAASTE FAMIIIEIEUEN?

$\square$ ja $\square$ nee

31. DRDNKT U WEL EGNS ALCOHOLBOUDENDE DRANR OM BEIER IE KUNNEN DERKEN ?

$\square$ ja $\quad \square$ nee

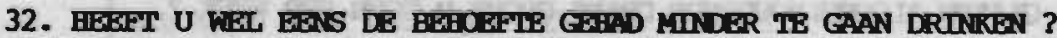<smiles>C1CCCC1</smiles>

33. AIS U ERS PAAR GAZEN HIFGFT GEDROKEN, KUNT U DAN ALITJD GROUDEN ALS U DAT WILT ?<smiles>CC1(C)CCC1</smiles> 


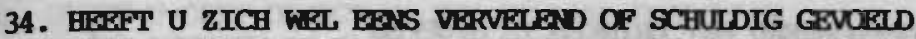
OVER UA DRTEKEN ?
$\square$ ja
nee

35. RAAKT U WEI, EEENS GETRRITHEIRD DOOR AANMERKINGEN VAN ANDEREN OVER UA DRANKGERRUIR ?
$\square$ ja
$\square$ nee

36. DRUNKT U KEL EIRS ALOOGOLAOUDENDE DRANK IN DE OCHIEND ?
$\square$ ja
$\square$ nee

37. DRTIKT U WELL EENS EEN PAAR GLAZEN AIOOHOL VOORDAT U NAAR EEN FEESTJE CAAT ?
ja
$\square$ nee

38. DRTNKT U WEL EENS ALCOBOLBOUDONDE DRANK OM UN ZORCEN TE VERGEIFN ?
$\square$ ja
nee

39. HEEFFT U, DE OCHIEND NADAT U GEDROATEN HAD HEL EMNS TRUIIENDE HANDEN GEHAD?

$\square$ ja $\square$ nee

40. VERZUDMT U hEL EFNS UN FERT TEN GEVOLEE VAN DRANRGERTUIR ?

$\square$ ja $\square$ nee 
41. HEEFT U hEL EENS GEROEERT MBT DRTKEN IE SIOPREN ZONDER DAT DAT LUKIE ?
$\prod$ ja
$\square$ nee

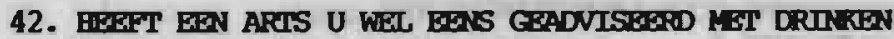
TE MTNEREN OF TE STOPPEN ?
$\square$ ja
$\square$ nee

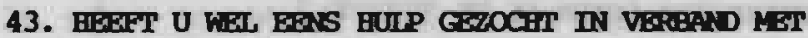
DRANKPROBI BAEN?
$\square$ ja
nee

44. SLAAT U WRL ERENS MAALITIDEN OVER IN ENAN PERIOCE

DAT U MEAR ATCOEOLAOUDENDE DRANK DRTIRT ?

$\square$ ja $\square$ nee

45. KUNT U UN KETR WRL EENS MINDER COED DOEN TIEN GEVOTEE VAN UA DRANKEEARUIR ?

$\square$ ja $\square$ nee

46. DRTNKT U KEL EFS'S AICOROMBOUDENDE DRANK OM U BEIER TE VOEIEN ?

$\square$ ja

$\square$ nee

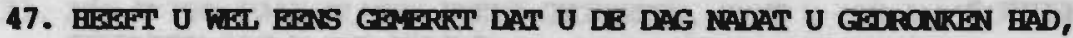
NIET MEGER WIST WAT U TIJDENS HEFT DRTNMEN BAD GEDAAN ?<smiles>C1CCC1</smiles> 
48. HEEFFT U OOIT DIRECT NA HIST OPSTANAN GEDRONKEN OM UN ZENUNEN DE BAAS TE KUNNEN WOROEN OF QY VAN EEEN KAIERR AF TE KOMEN ?

$\square$ ja nee

49. DRUNKT U WEL EENS STIEKKAM ?

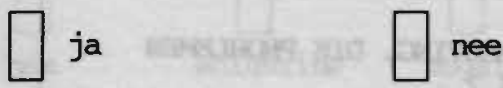

50. DRTIKY U KEL ENES ALCOAOLBOUDENDE DRANK OM BEIER TE WEIRKEN ?
$\square$ ja
$\square$ nee

51. IS WEL EEIS BIJ EREN POLTTIECONTROLE GEBIEKEN DAT U ALS BESTUURDER ONDER INVLOED VAN ALOOHOL KAS ?

$\square$ ja $\square$ nee

52. BENT U UW WERK WEL EEAS BIJNA OF BIETEMAAL KWIJTGERAAKT DOQR UA DRTNKEN ?

$\square$ ja $\square$ nee

53. HEEFT U hiRl ERES EEN ONGEVAL OF ONGEUUK GERAD IADHT U GEDRONKEN HAD ?

$\square$ ja $\square$ nee

54. IS UN ALOOAOLGEARUIK ER FIEL EENS (MEDE) OCRZAAR VAN GEMEEST DAT U IN EEN ZIFIKENAUIS/KUINIEK BENT OPGEMEN ?

ja nee 
55. BENT U DE AFGEIOPEN 12 MAANDEN WILL GESS DRONKEN GEMREST ?

$\prod$ ja

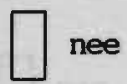

Zo ja, hoe valk ?

........ keer

56. ZIJN OF KAREN ER MENSEN IIN UA NAASIE OMEEVING, DIE PROBIGMEN HEABBEN OF HADDEN MET BUN ALCOROLGBBRUIK ?

(ook invullen, indien de persoon overleden is)
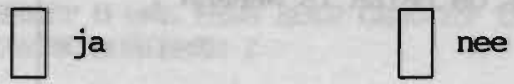

Zo ja, wie ? (eventueel meerdere hokjes aankruisen)

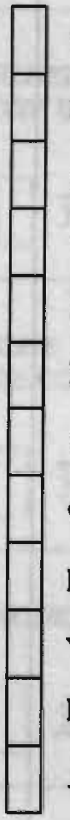

vader

moeder

schoonvader

schoonmoeder

kind(eren)

broer (s)

zuster(s)

grootouder(s)

partner

vrienden

buren

iemand anders, namelijk ........ 


\section{Tot slot volgen hier nog een paar algemene vragen.}

57. HEAEFT $U$ DE LAATSIE TIJD MOEIIIJKR GOEN OP UN WERK OF MBT HET (BUISEOUDETJK) KETK ?

Voorbeelden: ermstig meningsverschil met chef, collega's of ondergeschikten; werk/huishouding te veeleisend, te weinig waardering; dreiging werkloosheid; of iets anders.

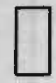

nee

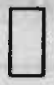

enigszins

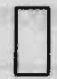

nogal

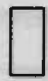

ernstig

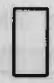

niet van toepassing

58. HIKEFT U DE LAATSTE TIJD FOELIJTKHEDEN OP SCAOOL OF MET UN STUDIE ?

Voorbeelden: opleiding te zwaar; konflikten met medeleerlingen/ cursisten of docenten; of iets anders.

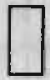

nee

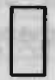

enigszins

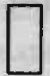

nogal

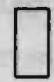

ernstig

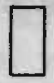

niet van toepassing

\section{HEEFT U DE LAATSE TIJD FINANCIE MOETIJKHEDEN ?}

Voorbeelden: schulden die u niet of naurelijks kunt betalen; een inkomen waarvan u niet of naumelijks kunt rondkamen; dreigend faillissement; of iets anders.

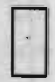

nee

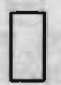

enigszins

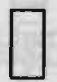

nogal

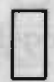

ernstig

60. HIEEFT U DE IAAISLE TIJD PROBUEMEN MBT UN GODSDIENST OF GEIOOF ?

Voorbeelden: bent $u$ iets anders gaan geloven dan uw gezinsleden; bent u gaan twijfelen aan de kerk; of iets anders.

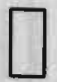

nee

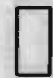

enigszins

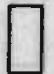

nogal<smiles>C1CCC1</smiles>

ernstig 


\section{ZIJN ER DE LAATSTE TIJD MOETIJJRBEDEN TUSSEN U EN UW}

PARITER ?

Voorbeelden: twijfel of $2 \mathrm{ij} / \mathrm{hij}$ wel de juiste partner voor $u$ is; angst on hem/haar te verliezen; konflikten over de opvoeding van uw kinderen; of iets anders.

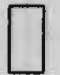

nee

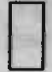

enigszins

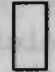

nogal

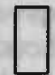

ernstig

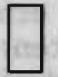

niet van toepassing

62. HEEST U DE LAATSILE TIJD SEXUEIE MOETIJKHIFDEN ?

Voorbeelden: konflikten met uw partner over sexualiteit; u raakt niet opgewonden; twijfel over hetero- of hamosexualiteit; u voelt $z$ ich sexueel onaantrekkelijk; of iets anders.

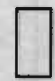

nee

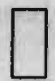

enigszins

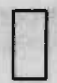

nogal

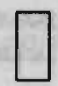

ernstig

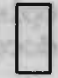

niet van toepassing

63. ZIJN ER DE LAATSTE TIJD MOETIJKHEDEN TUSSEN U EN UW OUDER(S) ?

Voorbeelden: slecht of niet met ze overweg kunnen; niet door hen geaccepteerd worden; erfeniskwesties; verwijten ze $u$ van alles; of iets anders.

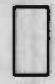

nee

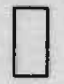

enigszins<smiles>C1CCC1</smiles>

nogal

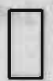

ernstig

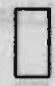

niet van toepassing

64. ZIJN ERR DE LAATSIE TIJD MOETIIJKHEDEN TUSSEN U EN EEN OF MEER VAN UA KUIDEREN ?

Voorbeelden: vrijwel kontinue konflikten; het slecht doen op school; tegen uw zin uit huis weg gaan; in het geheel geen respect voor u tonen; of iets anders.<smiles>C1CCC1</smiles>

nee<smiles>C1CCC1</smiles>

enigszins

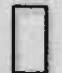

nogal<smiles>C1CCC1</smiles>

ernstig 
65. ZIJN ER DE LAAISTB TIJD MOEHITJKHEDGN TUSSEN U EN UW SCHOCA OUDERS ?

Voorbeelden: slecht of niet met ze overweg kunnen; niet door hen geaccepteerd worden; erfeniskwesties; verwijten ze $\mathrm{u}$ van alles; of iets anders.
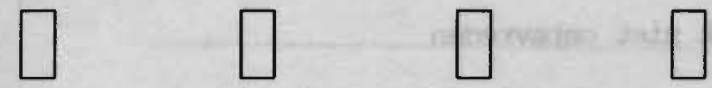

nee

enigszins

nogal

ernstig

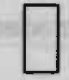

niet van

toepassing

66. ZIJN ER DE LAAISIE TIJD MOEHIJKHEDEN TUSSEN U EN EEN OF MEEER VAN UN BROERS/ZUSTERS ?

Voorbeelden: slecht of niet met ze overweg kunnen; niet door hen geaccepteerd worden; erfeniskwesties; verwijten ze u van alles; of iets anders.

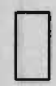

nee

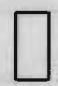

enigszins

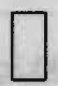

nogal

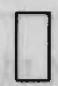

ernstig

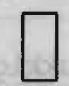

niet van toepassing

67. ZIJN ER DE IAATSIE TIJD MOEHIIJKHEDEN MET EEN OF MEERR MENSEN UIT DE BUURT ?

Voorbeelden: in verband met lawaaioverlast, vernielingen, bedreigingen; geroddel over $u$ of uw gezin; of iets anders.

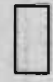

nee

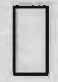

enigszins

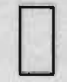

nogal

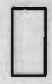

ernstig

68. ZIJN ER DE LAAISIE TIJD PROBIEMEN MET MENSEN DIE UN VRTENDEN OF KENNISSEN ZIJN OF WAREN ?

Voorbeelden: in verband met geroddel achter uw rug om; het niet nakomen van afspraken; geen gehoor geven toen $u$ hem/haar echt nodig had; of iets anders.

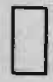

nee<smiles>C1CCC1</smiles>

enigszins

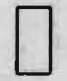

nogal<smiles>C1CCC1</smiles>

ernstig 
69. BOE TEVREDEN VOBLDE U ZICH ALIES BUJ EIKAAR GENOYEN DE IAAISTE TIJD?

zeer tevreden

tevreden

niet tevreden maar ok niet ontevreden

ontevreden

zeer ontevreden

70. HOE GELUKKIG VOETIE U ZICH ALUES BIJ EIKAAR GENOMEN DE LAATSTE TIJD ?

zeer gelukkig

gelukkig

niet gelukkig maar $\infty$ kiet ongelukkig

ongelukkig

zeer ongelukkig

71. HOE BEOOROEKELT U OVER HET ALGEMEEN UN EIGEN GEZONDHEID ?

zeer goed

goed

matig

slecht

zeer slecht 
Hartelijk dank voor het invullen van de vragenlijst. Indien u opmerkingen heeft, dan zijn deze welkom I 
Questions of the screening questionnaire in order of decreasing frequency of positive scores (number of positive scores). The source of each question is indicated: this may be CAGE', $\mathrm{SMAST}^{2}, \mathrm{SAAST}^{3}, \mathrm{Knibbe}^{4}$ or the present study. If the question belongs to the 18 Rasch homogeneous questions ${ }^{5}$, this is indicated as 'Rasch18'. The number of the question in the questionnaire and the Dutch translation is also given.

1: Have you ever felt that you should/you ought/the need to cut down on your drinking?

32: Heeft u wel eens de behoefte gehad minder te gaan drinken? CAGE/SAAST/RASCH18

2: Have you ever felt bad or guilty (do you ever feel quilty) about your drinking.

34: Heeft $\mathrm{u}$ zich wel eens vervelend of schuldig gevoeld over uw drinken?

CAGE/SMAST

3: Do you ever drink to feel better?

46: Drinkt u wel eens alcoholhoudende drank om $u$ beter te voelen? present study

4: Have you ever woken up in the morning, after drinking the night before, to find that you could not remember part of the evening?

47: Heeft $u$ wel eens gemerkt dat $u$ de dag nadat $u$ gedronken had, niet meer wist wat $\mathrm{u}$ tijdens het drinken had gedaan?

Knibbe

5: Do you ever drink to forget your worries?

38: Drinkt u wel eens alcoholhoudende drank om uw zorgen te vergeten?

present study/RASCH18 
6: Have you ever woken up in the morning after drinking the night before, to find that your hands were shaking?

39: Heeft u de ochtend nadat u gedronken had wel eens trillende handen gehad?

Knibbe

7: Do friends or relatives think you are a normal drinker?

28: Vinden uw partner en/of familieleden, vrienden of kennissen, dat $u$ teveel drinkt?

SMAST

8: Do close relatives (Does your wife, husband, a parent or other near relative) ever worry or complain about your drinking?

29: Maken uw partner en/of naaste familieleden zich wel eens zorgen over uw drankgebruik, of klagen ze er wel eens over?

MAST/SAAST/RASCH18

9: Have you ever been told by a doctor to stop drinking?

42: Heeft een arts $\mathrm{u}$ wel eens geadviseerd met drinken te minderen of te stoppen?

SAAST/RASCH18

10: Has (your) drinking ever created problems between you and your wife, husband, parent, or (other) near relative?

30: Heeft uw drankgebruik wel eens problemen veroorzaakt met uw partner en/of naaste familieleden?

SMAST/SAAST

11: Do you feel you are a normal drinker (by normal we mean that you drink less than or as much as most other people, drink no more than average)?

27: Vindt $\mathrm{u}$ dat $\mathrm{u}$ meer alcoholhoudende drank drinkt dan de meeste mensen?

SMAST/SAAST

12: Have people annoyed you by criticizing your drinking?

35: Raakt $u$ wel eens geïriteerd door aanmerkingen van anderen over uw drankgebruik? 
13: Do you ever have a few drinks before you go to a party?

37: Drinkt u wel eens een paar glazen alcohol voordat u naar een feestje gaat?

Knibbe/RASCH18

14: Do you ever skip meals when you are drinking?

44: Slaat $u$ wel eens maaltijden over in een periode dat $u$ meer drinkt? Knibbe/Rasch18

15: Are you (always) able to stop drinking when you want to?

41: Heeft $u$ wel eens geprobeerd met drinken te stoppen zonder dat lukte?

SMAST/SAAST/Knibbe/RASCH18

16: Can you stop drinking without a struggle after one or two drinks? 33: Als u een paar glazen gedronken heeft, kunt $u$ dan altijd ophouden als $\mathrm{u}$ dat wilt?

Knibbe/RASCH18

17: Have you ever gotten into trouble at work because of drinking?

45: Kunt u uw werk wel eens minder goed doen ten gevolge van uw drankgebruik?

SMAST

18: Driving while intoxicated, have you ever been arrested for drunken driving, driving while intoxicated, or driving under the influence of alcoholic beverages?

51: Is wel eens bij een politiecontrole gebleken dat $u$ als bestuurder onder invloed van alcohol was?

SMAST/SAAST

19: Have you ever had an accident after you had been drinking?

53: Heeft $u$ wel eens een ongeval of ongeluk gehad nadat $u$ gedronken had?

present study 
20: Have you ever had a drink first thing in the morning to steady your nerves or get rid of a hangover?

48: Heeft u ooit direct na het opstaan gedronken om uw zenuwen de baas te kunnen worden of om van een kater af te komen?

CAGE/RASCH18

(64)

21: Do you ever drink in the morning?

36: Drinkt u wel eens alcoholhoudende drank in de ochtend?

SAAST/Knibbe/RASCH18

(63)

22: Have you ever been in hospital because of drinking? Was drinking part of the problem that resulted in your hospitalization?

54: Is uw alcoholgebruik er wel eens (mede) oorzaak van geweest dat $\mathrm{u}$ in een ziekenhuis/kliniek bent opgenomen?

SMAST/SAAST/RASCH18

(46)

23: Have you ever gone to anyone for help about your drinking?

43: Heeft u wel eens hulp gezocht in verband met drankproblemen?

SMAST/RASCH18

24: Did you ever hide your drinking?

49: Drinkt u wel eens stiekem?

Knibbe/RASCH18

25: Do you ever drink to optimize your thinking?

31: Drinkt $\mathrm{u}$ wel eens alcoholhoudende drank om beter te kunnen denken?

present study/RASCH18

26: Have you ever neglected your obligations, your family or your work for two or more days in a row because you were drinking?

40: Verzuimt u wel eens uw werk ten gevolge van uw drankgebruik?

SMAST/RASCH18

(24)

27: Do you ever drink in order to work better?

50: Drinkt u wel eens alcoholhoudende drank om beter te kunnen werken? 
28: Have you ever lost a job because of your drinking?

52: Bent $\mathrm{u}$ uw werk wel eens bijna of helemaal kwijtgeraakt door uw drinken?

present study/RASCH18

Criteria for problem drinking:

CAGE $>1$ (score 2 and higher)

SMAST $>2$ (score 3 and higher)

SAAST $>2$

RASCH18 $>2$ 


\section{References}

1. Mayfield D, McLeod G, Hall P. The CAGE questionnaire: Validation of a new alcoholism screening instrument. Am J Psychiat 1974;131:1121-3.

2. Selzer ML, Vinokur A, Van Rooijen L. A self-administered Short Michigan Alcoholism Screening Test (SMAST). J Stud Alcohol 1975;36:117-26.

3. Davis LJ, Hurt RD, Morse RM, O'Brien PC. Discriminant analysis of the SelfAdministered Alcoholism Screening Test. Alcohol Clin Exp Res 1987;11:269-73.

4. Knibbe RA. Probleemdrinken in Limburg. Maastricht, Rapport University of Limburg, 1982.

5. Cornel M, Van Zutpen WM, Knibbe RA, Drop MA. Screening on problem drinking in a general practice population: the construction of an interval scale for severity of problem drinking. J Stud Alcohol, in press. 


\section{Distribution of basic characteristics of the study population}

Table 1: Number of persons eventually included in the study.

GP PD +/-: problem drinkers/not problem drinkers according to GPs.

Screening PD +/-: result of problem drinking screening test.

\begin{tabular}{l|cc|cc|l} 
& SCREENING & PD + & SCREENING & PD - & Response \\
\hline GP PD + & 86 & 36 & 122 \\
\hline GP PD - & 82 & 1201 & 1283 \\
\hline & 168 & 1237 & 1405
\end{tabular}

Admitted to study

Table 2: Number of persons eventually included in the study and with one year follow-up.

GP PD +/-: problem drinkers/not problem drinkers according to GPs.

Screening PD +/-: result of problem drinking screening test.

\begin{tabular}{|c|c|c|c|c|}
\hline & $\begin{array}{l}\text { SCREENING } \\
+\end{array}$ & PD & $\begin{array}{ll}\text { SCREENING PD } \\
-\end{array}$ & Response \\
\hline GP PD + & 81 & & 35 & 116 \\
\hline \multirow[t]{2}{*}{ GP PD - } & 78 & & 1176 & 1254 \\
\hline & 159 & & 1211 & 1370 \\
\hline
\end{tabular}

1 Year Follow-up Admitted to study 
Table 3: Numbers and percentages of known problem drinkers $(n=122)$, problem drinkers not known as such by the GPs $(n=82)$ and non-problem drinkers $(n=1201)$ in relation to categorical variables.

\begin{tabular}{|c|c|c|c|c|c|c|}
\hline 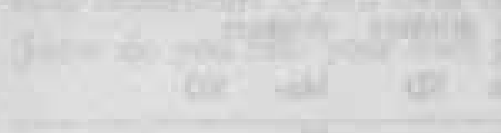 & $\begin{array}{l}\text { Kno } \\
\text { prob } \\
\text { drinl }\end{array}$ & & $\begin{array}{l}\text { Hid } \\
\text { pro } \\
\text { drin }\end{array}$ & & $\begin{array}{l}\text { Non } \\
\text { drinl }\end{array}$ & $\begin{array}{l}\text { iroblem } \\
\text { ars }\end{array}$ \\
\hline & $n$ & $\%$ & $n$ & $\%$ & $\mathrm{n}$ & $\%$ \\
\hline male gender & 97 & 79.5 & 69 & 84.1 & 564 & 47.0 \\
\hline $\begin{array}{l}\text { marital status, not married and not } \\
\text { living together }\end{array}$ & 43 & 35.2 & 34 & 41.5 & 348 & 29.1 \\
\hline living alone & 37 & 30.6 & 15 & 18.3 & 137 & 11.5 \\
\hline low educational level & 84 & 68.9 & 47 & 57.3 & 631 & 53.1 \\
\hline unemployed or disabled & 52 & 34.0 & 19 & 23.2 & 170 & 14.2 \\
\hline life events + & 56 & 47.5 & 41 & 51.3 & 346 & 29.5 \\
\hline chronic illness + & 50 & 41.7 & 30 & 37.0 & 348 & 29.6 \\
\hline sleeping pills + & 24 & 19.7 & 11 & 13.4 & 78 & 6.6 \\
\hline tranquillizer use + & 33 & 27.3 & 14 & 17.1 & 118 & 10.0 \\
\hline smoking + & 102 & 83.0 & 56 & 68.3 & 448 & 37.7 \\
\hline drunkenness + & 73 & 62.5 & 61 & 74.4 & 227 & 19.4 \\
\hline knowing problem drinkers + & 73 & 61.9 & 39 & 48.1 & 369 & 31.6 \\
\hline chronic illness partner + & 15 & 12.4 & 10 & 12.3 & 161 & 13.7 \\
\hline chronic illness child + & 11 & 9.0 & 6 & 7.4 & 45 & 3.8 \\
\hline illness $\geq 1$ month & 42 & 35.6 & 18 & 22.5 & 184 & 15.7 \\
\hline
\end{tabular}


Table 4: Mean values and standard errors of known problem drinkers $(\mathrm{n}=122)$, hidden problem drinkers $(\mathrm{n}=82)$ and non-problem drinkers $(\mathrm{n}=1201)$ in relation to interval variables.

\begin{tabular}{llllllll}
\hline Means and SD & \multicolumn{3}{l}{$\begin{array}{l}\text { Known pro- } \\
\text { blem drinkers }\end{array}$} & \multicolumn{2}{l}{$\begin{array}{l}\text { Hidden pro- } \\
\text { blem drinkers }\end{array}$} & \multicolumn{2}{l}{$\begin{array}{l}\text { Non-problem } \\
\text { drinkers }\end{array}$} \\
& Mean & SD & Mean & SD & $\begin{array}{l}\text { Me- } \\
\text { an }\end{array}$ & SD \\
\hline age & 45.7 & 12.2 & 38.7 & 14.3 & 42.6 & 16.8 \\
social problems & 4.1 & 4.3 & 4.1 & 4.0 & 1.8 & 2.6 \\
consultations/year & 3.1 & 2.4 & 2.9 & 2.0 & 2.8 & 2.1 \\
drinks/day & 7.2 & 10.2 & 4.4 & 3.8 & 0.9 & 1.5 \\
\hline
\end{tabular}


The questionnaire comprises questions about physical, psychological and social self estimated functioning. The 6 tables below show the numbers and row percentages in the categories of known problem drinkers, hidden problem drinkers and non-problem drinkers in relation to the categories good, moderate and bad.

Hoe beoordeelt U zelf over het algemeen uw lichamelijk functioneren? (How do you rate your own physical functioning?)

\begin{tabular}{lllll}
\hline & good & moderate & bad & total \\
\hline Known PDs & $59(49.1 \%)$ & $44(36.7 \%)$ & $17(14.2 \%)$ & $120(100 \%)$ \\
Hidden PDs & $54(65.9 \%)$ & $20(24.4 \%)$ & $8(9.7 \%)$ & $82(100 \%)$ \\
\hline Non-PDs & $848(71.2 \%)$ & $311(26.1 \%)$ & $31(2.7 \%)$ & $1191(100 \%)$ \\
\hline
\end{tabular}

Hoe beoordeelt U zelf over het algemeen uw psychisch functioneren? (How do you rate your own psychological functioning?)

\begin{tabular}{lllll}
\hline & good & moderate & bad & total \\
\hline Known PDs & $72(60.0 \%)$ & $41(34.2 \%)$ & $7(5.8 \%)$ & $120(100 \%)$ \\
Hidden PDs & $60(73.2 \%)$ & $19(23.2 \%)$ & $3(3.6 \%)$ & $82(100 \%)$ \\
Non-PDs & $986(82.9 \%)$ & $176(14.8 \%)$ & $28(2.3 \%)$ & $1190(100 \%)$ \\
\hline
\end{tabular}


Hoe beoordeelt $\mathrm{U}$ zelf over het algemeen uw eigen gezondheid? (How do you rate your own health status?)

\begin{tabular}{lllll}
\hline & good & moderate & bad & total \\
\hline Known PDs & $57(47.1 \%)$ & $53(43.8 \%)$ & $11(9.1 \%)$ & $121(100 \%)$ \\
Hidden PDs & $50(61.0 \%)$ & $27(32.9 \%)$ & $5(6.1 \%)$ & $82(100 \%)$ \\
Non-PDs & $844(71.0 \%)$ & $321(27.0 \%)$ & $24(2.1 \%)$ & $1189(100 \%)$ \\
\hline
\end{tabular}

Hoe vindt $U$ dat $U$ tegen de problemen van het dagelijks leven bent opgewassen?

(How do you rate your own ability to cope with problems of daily life?)

\begin{tabular}{lllll}
\hline & good & moderate & bad & total \\
\hline Known PDs & $63(52.5 \%)$ & $42(35.0 \%)$ & $15(12.5 \%)$ & $120(100 \%)$ \\
Hidden PDs & $53(64.6 \%)$ & $22(26.8 \%)$ & $7(8.5 \%)$ & $82(100 \%)$ \\
Non-PDs & $921(77.5 \%)$ & $228(19.2 \%)$ & $40(3.4 \%)$ & $1189(100 \%)$ \\
\hline
\end{tabular}

Hoe tevreden voelde $U$ zich alles bij elkaar genomen de laatste tijd? (How content have you felt recently?)

\begin{tabular}{lllll}
\hline & good & moderate & bad & total \\
\hline Known PDs & $54(44.2 \%)$ & $49(40.2 \%)$ & $19(15.6 \%)$ & $122(100 \%)$ \\
Hidden PDs & $48(59.2 \%)$ & $26(32.1 \%)$ & $7(8.6 \%)$ & $81(100 \%)$ \\
Non-PDs & $881(74.1 \%)$ & $271(22.8 \%)$ & $38(3.2 \%)$ & $1190(100 \%)$ \\
\hline
\end{tabular}


Hoe gelukkig voelde $\mathrm{U}$ zich alles bij elkaar genomen de laatste tijd? (How happy have you felt recently?)

\begin{tabular}{lllll}
\hline table & good & moderate & bad & total \\
\hline Known PDs & $50(41.3 \%)$ & $57(47.1 \%)$ & $14(11.6 \%)$ & $121(100 \%)$ \\
Hidden PDs & $43(52.5 \%)$ & $32(39.0 \%)$ & $7(8.5 \%)$ & $82(100 \%)$ \\
Non-PDs & $825(69.5 \%)$ & $326(27.5 \%)$ & $36(3.1 \%)$ & $1187(100 \%)$ \\
\hline
\end{tabular}




\section{Detection of Problem drinkers in General Practice}

\section{Michiel Cornel}

General practitioners (GPs) often do not recognize problem drinkers among their patients, although problem drinking is a major social and health problem. GPs lack adeqate diagnostic tools for the recognition of problem drinkers. In this study, background data (e.g. gender, social problems) and consultation data (e.g. reasons for encounter) are studied as predictors of hidden problem drinking. A follow-up study was conducted in the practices of $16 \mathrm{GPs}$.

All problem drinkers known as such to the GPs and a one in ten random sample of the rest of the practice population were studied. In the latter category hidden problem drinkers were detected by a Rasch homogeneous questionnaire which was constructed in this study. The prevalence of problem drinking was found to be $7 \%$. Of the problem drinkers, $10 \%$ was recognized as such by the GPs.

Smoking men with chronic social problems and recent life events were especially at risk of being hidden problem drinkers. Reasons for encounter and diagnoses are of limited value in the detection of hidden problem drinkers.

Michiel Cornel was born in 1958 in Utrecht, the Netherlands. During his medical studies in Groningen he worked as an assistant in a project studying oxygen tension measurement in the fetus during labour. He spent his military service working as a doctor at Leeuwarden Air Base, where he discovered the attraction of general practice. Since 1987 he has been working as a part-time researcher at the University of Limburg and as part-time general practitioner.

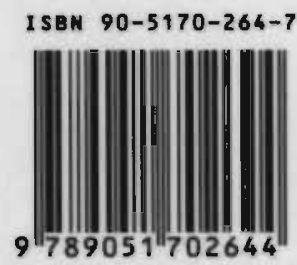

NUGI 741 